San Jose State University

SJSU ScholarWorks

Master's Theses

Master's Theses and Graduate Research

Fall 2013

\title{
Benthic Invertebrate Response to Habitat Complexity in South Bay Salt Ponds
}

Jessica Louise Murphey

San Jose State University

Follow this and additional works at: https://scholarworks.sjsu.edu/etd_theses

\section{Recommended Citation}

Murphey, Jessica Louise, "Benthic Invertebrate Response to Habitat Complexity in South Bay Salt Ponds"

(2013). Master's Theses. 4397.

DOI: https://doi.org/10.31979/etd.hw8u-mt6r

https://scholarworks.sjsu.edu/etd_theses/4397

This Thesis is brought to you for free and open access by the Master's Theses and Graduate Research at SJSU ScholarWorks. It has been accepted for inclusion in Master's Theses by an authorized administrator of SJSU ScholarWorks. For more information, please contact scholarworks@sjsu.edu. 
BENTHIC INVERTEBRATE RESPONSE TO HABITAT COMPLEXITY IN SOUTH BAY SALT PONDS

\author{
A Thesis \\ Presented to \\ The Faculty of the Department of Environmental Studies \\ San José State University
}

\author{
In Partial Fulfillment \\ of the Requirements for the Degree \\ Master of Science
}

by

Jessica L. Murphey

December 2013 
(C) 2013

Jessica L. Murphey

ALL RIGHTS RESERVED 
The Designated Thesis Committee Approves the Thesis Titled

BENTHIC INVERTEBRATE RESPONSE TO HABITAT COMPLEXITY IN SOUTH

BAY SALT PONDS

by

Jessica L. Murphey

APPROVED FOR THE DEPARTMENT OF ENVIRONMENTAL STUDIES

SAN JOSÉ STATE UNIVERSITY

December 2013

Dr. Lynne Trulio Department of Environmental Studies

Dr. Rachel O’Malley Department of Environmental Studies

Dr. Will Russell Department of Environmental Studies

Ms. Isa Woo United States Geological Survey 


\begin{abstract}
BENTHIC INVERTEBRATE RESPONSE TO HABITAT COMPLEXITY IN SOUTH
\end{abstract} BAY SALT PONDS

by Jessica L. Murphey

Wetlands are unique ecosystems that support specific flora, fauna, hydrology, and geology. These ecosystems increase groundwater availability, improve water quality, decrease flood water impacts, and help decrease shoreline erosion. In the south San Francisco Bay, the South Bay Salt Pond Restoration Project is restoring over 6,000 hectares of former salt ponds to tidal marshes and managed pond habitats. These habitats will support endangered species as well as migratory birds, diving ducks, invertebrates, and algal species. Benthic invertebrates are a vital piece of the South Bay food web as they provide the sustenance for other invertebrates, fish, shorebirds, and waterfowl. Improving the health of benthic communities in existing ponds is expected to attract more birds to those ponds and improve the overall health of the South Bay.

This study assessed the relationship between invertebrate diversity, species richness, and density at two types of structures--bird islands and wood posts--in two managed ponds in the South Bay. Neither structure significantly affected these benthic parameters, although there was a trend toward more organisms and diversity at structure versus non-structure sites. Differences were significant between ponds and seasons. The results of this work can be used by resource managers to maintain or improve current levels of avian foraging in existing ponds through appropriate pond management in the South Bay salt ponds. 


\section{ACKNOWLEDGEMENTS}

First, I would like to thank my family for their continued support and motivation. My parents, Paul and Laurie Murphey, and sisters, Laura and Katie, provided emotional and physical support throughout this project, helping sieve and sort, or providing laughs and words of encouragement. I also thank my family for their encouragement when I decided to change my career and pursue my Master's degree in Environmental Studies.

I would like to thank my field assistant, Adam Remmel, who volunteered his time to kayak around SF2 and A1, taking numerous benthic cores for several hours on the weekends and fighting against early mornings, tides, onshore winds, and soft pond mud. I would also like to thank my other assistant, Jan Remmel, who volunteered to help sieve hundreds of benthic cores and allowed me to use her home and backyard for various stages of my project. Without her help, my project would have been beyond challenging.

I would like to thank my lab assistant, Minako Nishiyama, for her help sorting and identifying invertebrates. Minako learned how to sort and identify invertebrates without any previous experience, and always had a positive attitude, no matter how monotonous the work was. I'd also like to thank Dr. Joshua Mackie from San José State University Biology department for allowing Minako and me to use his lab space and equipment.

Dr. Lynne Trulio was not only my thesis chair, but also an advisor to me throughout my environmental program. She challenged me to broaden my thought processes, and then narrow my research scope when my ideas became too grandiose. Dr. Trulio not only assisted with my research project, but also provided emotional support 
when parts of the process became difficult or stressful. She became a mentor I discussed ideas with and who I could rely on when I needed help. I would also like to extend my gratitude to my committee members Dr. Rachel O’Malley and Dr. Will Russell from San José State University and Ms. Isa Woo from the United States Geological Survey who provided support and guidance throughout my project.

I would also like to thank Ms. Ashley Smith from the United States Geological Survey for her assistance with equipment, standard operating procedures, and insight on what research resource managers would most appreciate. Finally, I would like to thank Ms. Cheryl Strong from the United States Fish and Wildlife Service, the United States Fish and Wildlife Service, and the Don Edwards San Francisco Bay Wildlife Refuge for permitting access to the sites and providing sampling equipment.

Financial support from the San José State University College of Social Science Research Grant Foundation and Graduate Studies and Research Graduate Equity Fellowship was greatly appreciated. 


\section{TABLE OF CONTENTS}

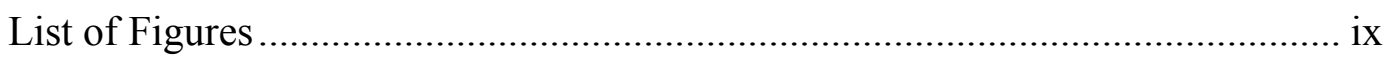

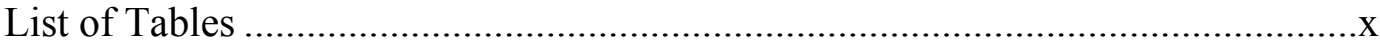

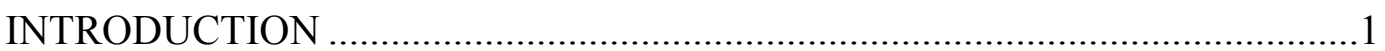

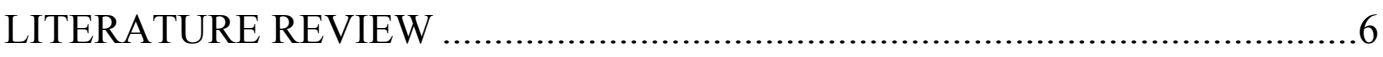

Habitat Complexity and Biodiversity …………………….......................6

Intermediate Disturbance Hypothesis ......................................................

South Bay Salt Ponds History ……….......................................................

Salt Pond Qualities...................................................................................

Invertebrates in the South Bay Salt Ponds ...................................................14

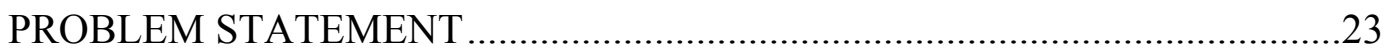

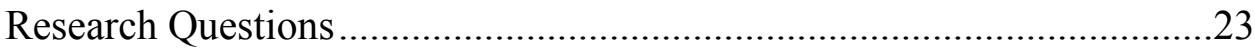

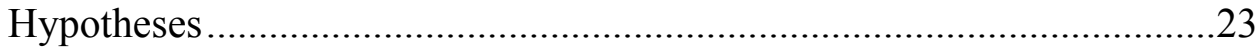

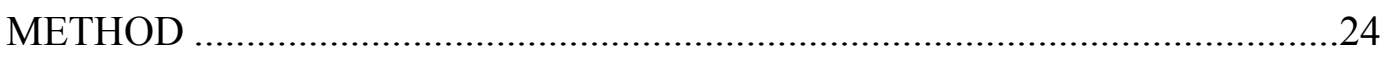

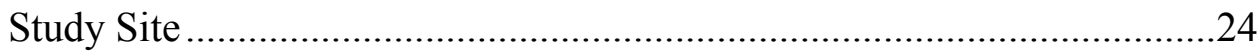

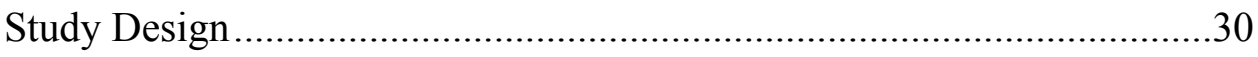

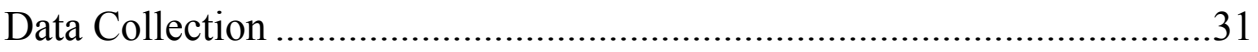

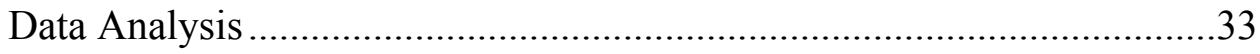

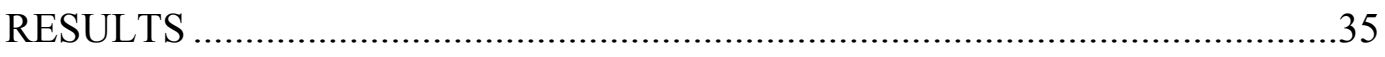

Qualitative Pond Characteristics.................................................................35

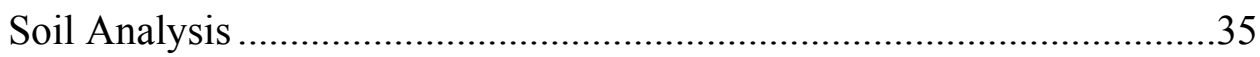




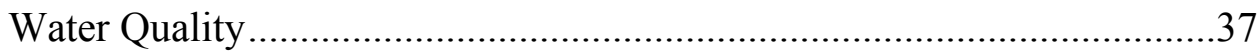

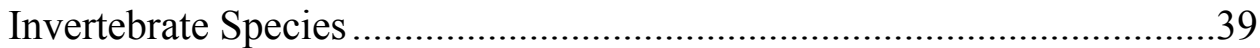

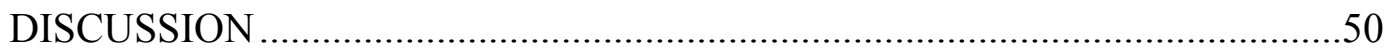

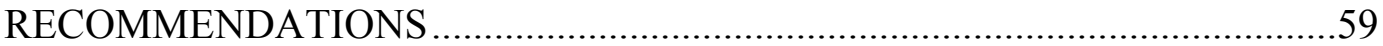

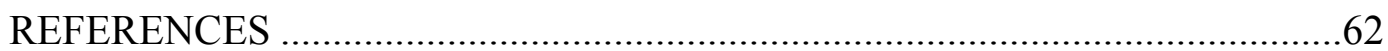

APPENDIX A: SF2 summer invertebrate identification .................................77

APPENDIX B: SF2 fall invertebrate identification...........................................

APPENDIX C: A1 summer invertebrate identification....................................79

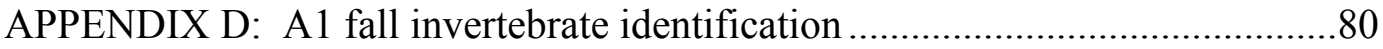

APPENDIX E: Critical Values of the Spearman's Ranked Correlation Coefficient (rs) (Zar, 1984). 


\section{LIST OF FIGURES}

Figure 1. San Francisco Bay Area .................................................................25

Figure 2. South Bay salt ponds with SF2 and A1 near East Palo Alto and Mountain View, California respectively ......................................................25

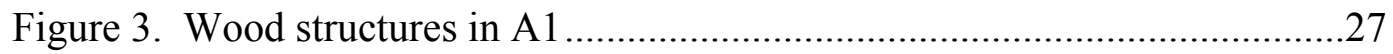

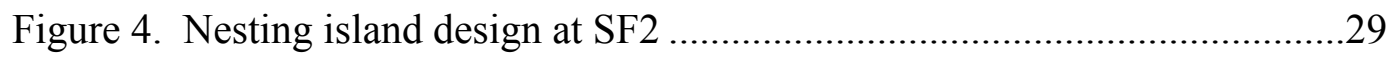

Figure 5. SF2 pond design with seven structure sampling sites .......................29

Figure 6. Mean $( \pm \mathrm{SE})$ water quality data for SF2 and A1 in summer and fall....39

Figure 7. Mean $( \pm \mathrm{SE})$ individuals for SF2 and $\mathrm{A} 1$ in summer and fall ..............40

Figure 8. SF2 broad invertebrate taxa diversity for summer and fall .................41

Figure 9. SF2 feeding group diversity for summer and fall...........................42

Figure 10. SF2 habitat group diversity for summer and fall ............................42

Figure 11. Broad invertebrate taxa diversity in A1 in summer and fall ..............43

Figure 12. Feeding group diversity in pond A1 for summer and fall .................43

Figure 13. A1 habitat functional group diversity for summer and fall ................44

Figure 14. Mean ( \pm SE) species richness for SF2 and A1 (summer and fall)

for structure and no structure ..................................................................... 47

Figure 15. Mean ( $\pm \mathrm{SE}$ ) diversity for SF2 and A1 (summer and fall) for

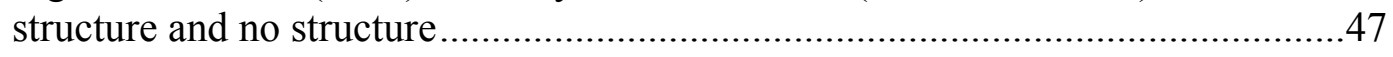

Figure 16. Mean ( $\pm \mathrm{SE})$ density for SF2 and A1 (summer and fall) for structure and no structure

Figure 17. Mean ( \pm SE) benthic abundance for SF2 and A1 (summer and fall) for structure and no structure. 


\section{LIST OF TABLES}

Table 1. Invertebrates of South Bay salt ponds: Alviso, Eden Landing and Ravenswood complexes

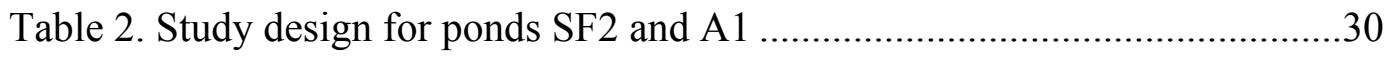

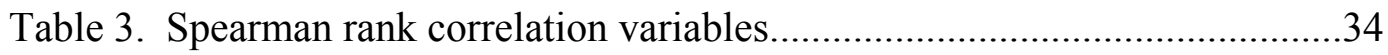

Table 4. ANCOVA, ANOVA, and Kruskal-Wallis variables .............................35

Table 5. Qualitative characteristics of SF2 and A1 in summer and fall ...............36

Table 6. Water quality results for SF2 and A1 in summer and fall .....................36

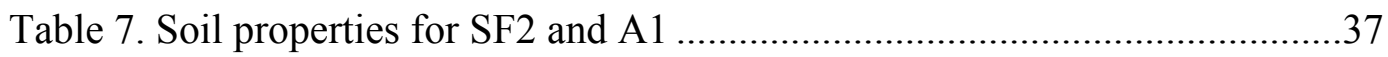

Table 8. Common invertebrates $(n>10)$ for SF2 and A1 ...............................40

Table 9. Regression results of water quality parameters on benthic invertebrate

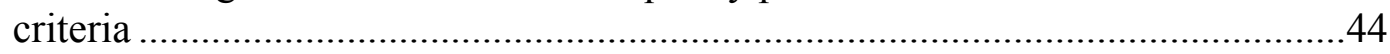

Table 10. Correlation results of water quality parameters on benthic invertebrate

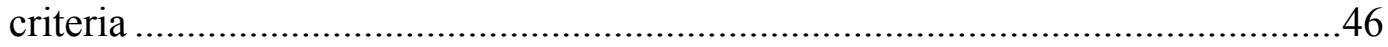

Table 11. Two-way ANCOVA and ANOVA results for structure and season effects for SF2 and A1 ....

Table 12. Results from Kruskal-Wallis tests for structure and season effects

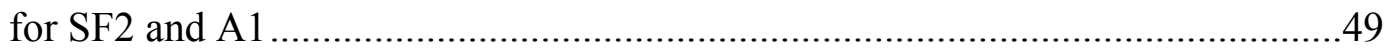




\section{Introduction}

Wetlands provide habitat for diverse plants and animals, including over $35 \%$ of the threatened or endangered species in the United States (United States Environmental Protection Agency [U.S. EPA], 2010). In addition, many migratory birds feed in the wetlands during the fall and spring during their journey to their summer and winter destinations (U.S. EPA, 2010). However, many wetlands have been destroyed or degraded, including the thousands of acres of former tidal marshes along the San Francisco Bay in California.

In the mid-1850s, the state of California considered tidal marshes as wasted space and therefore sold the land for one dollar per acre (Strange, 2008). The San Francisco Bay tidal marshes were filled with soil taken from building projects or soil that was dredged from Bay channels (Strange, 2008). Thousands of acres of tidal marshes in the South San Francisco Bay were converted to salt evaporation ponds, which provided important foraging habitat for shorebirds, waterfowl, fish, and other marine organisms due to the variety of benthic invertebrates that inhabited the ponds. These ponds were then sold to the state and federal government, 150 years after their conversion, as part of the South Bay Salt Pond Restoration Project (South Bay Salt Pond Restoration Project, 2011).

The South Bay Salt Pond Restoration Project aims to restore 6,111 hectares of former salt ponds in the South Bay to tidal marshes and managed ponds. In order for the managed ponds to remain ecologically significant, the habitat quality of the ponds needs to be improved. One such habitat improvement includes increasing benthic invertebrate 
richness, diversity, and density to continually support the species that rely on them for food. The purpose of this study is to characterize the benthic invertebrates at two intake ponds and determine whether the presence of habitat structures will positively influence invertebrate species richness, diversity, and density. Restoration managers will be able to use this information to increase their understanding of benthic invertebrate populations in two intake salt ponds and determine whether habitat structures should be added to managed ponds, if shown to be beneficial.

The San Francisco Bay Area, located in Central California, is the largest estuary on the west coast and tidal marsh ecosystems fringe the shoreline, especially in the North and South Bays. The formation of the San Francisco Bay began 10,000 to 15,000 years ago with the glacial melting that coincided with freshwater intrusion from the Sacramento and San Joaquin Rivers (Goman, Malamud-Roam, \& Ingram, 2008). Around 15,000 years ago, the area of the current San Francisco Bay was not a bay, but rather an area of river valleys from the Sacramento and San Joaquin Rivers (Atwater, Hedel, \& Helley, 1977). More than 10,000 years ago, the Sacramento River flowed through the current location of the Golden Gate out to the Pacific Ocean (Holloran, 1998). The rise of the sea levels between 5,000 and 10,000 years ago, due to climate, created the present San Francisco Bay through the flooding of the previous river regions and deltas (Goman et al., 2008). The development of tidal marshes along the edge of the Bay from an increase in sedimentation, led to an increase in salt-tolerant plants and tidal conditions, similar to the present-bay conditions (Goman et al., 2008). The tidal marshes and wetlands 
continued to develop from the sedimentation brought down from the Sacramento and San Joaquin rivers.

In the current San Francisco Bay estuary, dominant wetland habitats include mudflats, tidal marshes, panes, ponds, and sloughs (South Bay Salt Pond Restoration Project, 2010). Historically, tidal marshes extended far inland from the Bay and the Delta rivers. Historic tidal marshes were diked for agricultural and urban use, resulting in only about $10-15 \%$ of the 1850 s area of tidal marshes remaining (Dedrick, 1989; Ver Planck, 1958). In particular, in the South Bay, thousands of acres were diked off from the Bay for salt ponds. This conversion process was started in 1854 by Captain John Johnson, a failed gold miner and San Francisco dockworker (Mapelli, personal communication, 2011; San Francisco Bay Conservation and Development Commission, 2005; Strange, 2008). Johnson converted the tidal marshes along the Alameda shoreline (in the Eden Landing complex) into commercial salt ponds by dredging nearby channels using a floating dredge that scraped mud and began piling the debris into levees, typically on top of marshes (Mapelli, personal communication, 2011; San Francisco Bay Conservation and Development Commission, 2005). Other entrepreneurs, in response to an increased demand for salt in Nevada for processing silver ore, began following Johnson's lead by converting tidal marshes and upland areas into commercial salt ponds (Speulda-Drews \& Valentine, 2009). This significant reduction in tidal marshes has reduced aquatic populations, bird numbers, and wetland values important to people.

Tidal salt marshes provide habitat for many diverse and rare species and provide many beneficial uses, such as effluent filtering and salt production. The tidal marshes 
support more endemic taxa than any other single coast locality (Greenberg, Maldonado, Droege, \& McDonald, 2006) and provide effluent filtering, supply water recharge, and act as nutrient traps and chemical sinks (Emergency Wetlands Act, 1986). Dominant salt marsh plants, such as cordgrass (Spartina spp.), pickleweed (Salicornia spp.), salt grass (Disticalis spp.), and frankenia (Frankenia spp.), produce large amounts of organic material that contributes to nutrient and carbon cycling, as well as provides food for the resident wildlife (Philip Williams \& Associates \& Faber, 2004). The tidal marshes also act as natural protection by controlling flooding and erosion by retaining water during large amounts of runoff.

With only $10-15 \%$ of historic tidal marshes remaining in the San Francisco Bay, restoration goals seek to increase the number of tidal marshes and maintain thriving salt water ponds for wildlife refuges and habitats (San Francisco Bay Regional Water Quality Control Board, 2000). While the ponds used for salt production in the South Bay are not characterized as a natural part of the tidal marshes, their existence has created habitats and feeding grounds for many species of shorebirds, waterfowl, and other wildlife. These salt ponds contain diverse invertebrates and algae and are recognized as sites that support large populations of waterfowl and shorebirds due to the large benthic invertebrate populations. In 2003, the South Bay Salt Pond Restoration Project began planning to restore at least half of the 6,111 hectares of South Bay salt ponds to fully tidal marshes without reducing the numbers of migratory wildlife using the salt ponds (South Bay Salt Pond Restoration Project, 2010). Thus, the remaining number of ponds would need to 
support twice the numbers of wildlife as in the past. To do this, the habitat quality of the ponds must be increased.

One way to increase ecosystem function may be to improve the quality of the benthic invertebrate community. Large, diverse, healthy populations of benthic species are important in the success of the restoration goals because these invertebrates are essential to the aquatic ecosystem functioning (Batzer, Cooper, \& Wissinger, 2006; Rader, 2001; Wissinger, 1999). Invertebrates contribute to decomposition and nutrient cycling (Cummins, 1973; Merritt, Cummins, \& Burton, 1984) and provide sustenance for shorebirds, waterfowl, and other wildlife (Anderson \& Smith, 1999; De Szalay \& Resh, 1996; Wissinger, 1999). The benthic invertebrates act as water quality indicators due to their ability to quickly adapt to physical and chemical changes in the ecosystem (Anderson \& Smith, 2004; Brooks, 2000; Furse et al., 2006). Improvements in the benthic invertebrate community potentially can be achieved through increasing the structural heterogeneity in the ponds. Due to the significance of benthic invertebrates, research on the factors that improve benthic abundance and diversity, such as water quality, seasonal water fluctuations, and the types of structures used at the South Bay salt ponds, is important to the South Bay Salt Pond Restoration Project managers. Managers of salt ponds elsewhere may also be able to use results of this study to improve habitat conditions. 


\section{Literature Review}

\section{Habitat Complexity and Biodiversity}

Benthic invertebrates thrive in sediment surface or sub-sediment layers. The addition of habitat complexity through physical structures, such as rocks, woody debris, or root structures, can increase the abundance and diversity of the benthics. The speciesarea relationship theory suggests that additional habitat complexity and heterogeneity does not increase diversity of species, but rather a larger habitat size during sampling increases diversity (Coleman, 1981; Connor \& McCoy, 1979; MacArthur \& Wilson, 1967; Ricklefs \& Lovette, 1999; Simberloff, 1976; Williams, 1943).

However, Matias, Underwood, Hochuli, and Coleman (2010) claim that this theory does not apply well to benthic invertebrates. Habitat complexity results from variations in the physical structures of the ecosystem (Downes, Lake, Schreiber, \& Glaister, 1998; McCoy \& Bell, 1991); heterogeneity, or patchiness, is horizontal variation of habitat physiognomy (August, 1983). Matias et al. (2010) argue that increases in structural complexity of a habitat increase biodiversity through the inclusion of a variety of niches (Huston, 1994; Huston, 1997; Tilman, Lehman, \& Thomson, 1997; Tilman, 1999).

Wood is highly beneficial as a habitat structure in aquatic ecosystems, especially for invertebrates that use the wood for feeding (Bilby \& Bisson, 1998; Harmon et al., 1986; Sedell, Bisson, Swanson, \& Gregory, 1988). Vegetative structures, such as roots or woody debris, can contribute to the richness and abundance of aquatic species. For example, Kon, Kurokura, and Tongnunui (2009) studied mangroves and found that 
benthic invertebrates preferred the root structures in the absence of predators. The root structures were used not only by climbing invertebrates but also by burrowing invertebrates that used the roots to provide structure to the soft soils (Kon et al., 2009).

Altering the bathymetry of the South Bay salt ponds to increase heterogeneity would be expensive and difficult. However, the addition of habitat structures may be easier to implement and may increase benthic invertebrate diversity and abundance through additional habitat complexity. This study assessed whether pond structures may already be a factor in increased benthic diversity.

\section{Intermediate Disturbance Hypothesis}

Most benthic communities are dominated by species that can colonize quickly, and populations fluctuate in response to water fluctuations (Leland \& Fend, 1998; McRae, Camp, Lyons, \& Dix, 1998; Nichols, 1979). These habitat fluctuations can be caused by a variety of disturbances that result in the loss of biomass from the community, influence species coexistence, and biodiversity (Connell, 1978; Grime, 1977; Huston, 1979). The intermediate disturbance hypothesis predicts that the frequency of these disturbances affects the species diversity of the ecosystem (Connell, 1978). If disturbances occur at a high frequency, species diversity will be low because only organisms that can colonize quickly are able to survive. Similarly, if disturbances are low in frequency, species diversity will also be low because competitively dominant species will outcompete inferior species. Only when disturbances occur at an intermediate rate will species diversity be maximized because colonizers and competitors will co-exist (Hughes, 2012). 
Sousa (1979) studied the intermediate disturbance hypothesis in marine macroalgal communities growing on boulders in the marine intertidal zone. Sousa demonstrated this hypothesis based on the frequency of boulder movement by wave action and boulder size. Since boulder movement is inversely proportional to boulder size, Sousa demonstrated that small boulders would contain colonizing algal species, large boulders would contain competitively dominant algal species, and intermediate boulders would have the highest algal diversity.

Benthic invertebrates at the South Bay salt ponds are exposed to a variety of disturbances, such as predators and water quality fluctuations. This study assessed whether migratory bird foraging and seasonal water quality changes affected benthic diversity.

\section{South Bay Salt Ponds History}

Use of tidal marshes and natural salt pans around the San Francisco Bay for salt began with the Ohlone Native Americans who used these wetlands for food, water, and other resources. The Ohlone used the natural salt pans to collect salt for trade and to preserve food (Speulda-Drews \& Valentine, 2009). In 1769, the Spanish officially landed at San Diego and began the period of Spanish rule until Mexico gained control of California in 1821 (Field, 1914). The Spanish and Mexican settlers used the Ohlone methods of salt collection for sale of salt. The salt collection methods of the Ohlone, Spanish, and Mexican settlers did not significantly manipulate the tidal marsh and salt pond environment. However, after the Gold Rush, collecting salt within the San 
Francisco Bay for commercial profit began and the environment was manipulated for this goal.

An estimated $85 \%$ of historic tidal marshes were lost in the South San Francisco Bay due to development and commercial salt production when thousands of acres of tidal marsh were converted to commercial salt production ponds through diking of the marshes (San Francisco Bay Conservation and Development Commission, 2005; Strange, 2008). These enterprises were initially family-owned, but were eventually acquired by a single corporation, the Leslie Salt Company, in the 1920s. By the end of the 1950s, salt production had increased to almost one million metric tons from 16,605 hectares of salt ponds (San Francisco Bay Conservation and Development Commission, 2005). By the late 1960 s, 16,800 hectares were held under private ownership. These private lands owned by Leslie Salt Company were bought by Cargill, Incorporated in 1978 (Mapelli, personal communication, 2011).

In 2003, after negotiations with a number of state and federal agencies, Cargill sold 6,677 hectares of salt ponds in the North and South Bay to the California Department of Fish and Wildlife and the United States Fish and Wildlife Service for restoration (Mapelli, personal communication, 2011). The 6,111 hectares of ponds sold by Cargill in the South Bay became the focus of the South Bay Salt Pond Restoration Project, the largest wetland restoration on the west coast. The U.S. Fish and Wildlife Service, California Department of Fish and Wildlife, and California Coastal Conservancy began the South Bay Salt Pond Restoration Project. The goals of the South Bay Salt Pond Restoration Project included: 1) restoring habitat for tidal marsh and salt pond 
wildlife, 2) enhancing flood protection for the South Bay, and 3) creating compatible public use with wildlife (Strong, personal communication, 2011).

To ensure that tidal marsh and salt pond habitats were restored without significant negative impacts to the environment, an Environmental Impact Report and Environmental Impact Statement were completed to meet California Environmental Quality Act and National Environmental Protection Act requirements (Strong, personal communication, 2011). Permits for restoration were also obtained from the United States Army Corps of Engineers, Regional Water Quality Control Board, San Francisco Bay Conservation and Development Commission, United States Fish and Wildlife Service, California Department of Fish and Wildlife, and a biological opinion was obtained from the United States Fish and Wildlife Service office in Sacramento, California (Strong, personal communication, 2011). The three overarching goals of the project--habitat restoration, flood protection, and recreation--were incorporated into restoration designs that were aimed to mimic natural processes, provide habitat for sensitive wildlife, and create a viable system (Strong, personal communication, 2011).

This wetland restoration project is expected to significantly increase the area of tidal marsh and maintain thriving salt ponds for pond-dependent species. The South Bay Salt Pond Restoration Project aims to restore 6,111 hectares of former salt ponds in the South Bay ponds (South Bay Salt Pond Restoration Project, 2011). Decommissioned salt production ponds will be restored to tidal wetland habitat through many phases of restoration using an adaptive management program (Strong, personal communication, 2011). Using restoration targets developed during planning, the project managers will 
determine how much of the 6,111 hectares can be restored to salt marsh while still providing for the diversity and abundance of species that use the salt ponds.

This restoration project aims to restore at least $50 \%$ of the ponds to tidal wetlands. The remaining large ponds, while not a historically major component of the tidal wetlands in the San Francisco Bay area, will be maintained as managed ponds because they provide important habitat diversity for a variety of shorebirds, waterfowl, and other wildlife (Takekawa et al., 2006). These ponds have been recognized as sites of "hemispheric importance for shorebirds" because they support $30 \%$ of the populations in the Pacific Flyway and 50\% of the populations of diving ducks (Aythyinae sp.) (Accurso, 1992; Page, Stenzel, \& Wolfe, 1999; Takekawa et al., 2006). While the constructed saltproduction ponds of the South Bay salt ponds may not have originally been a natural habitat in the region, over time the ponds have evolved to support a variety of wildlife, including endangered species. Due to the great ecological importance of the ponds today, the functions of the ponds, especially invertebrate life cycles, must be better understood in order to maintain and improve the ponds' ecological importance in the future. Reducing the number of ponds will reduce habitat for these pond-dependent species. Thus, the remaining number of ponds must support a significant number of animals, resulting in the need for thriving aquatic ecosystems and successful restorations.

\section{Salt Pond Qualities}

Ponds in the South Bay Salt Pond Project are categorized as either low-, medium-, or high-salinity ponds based on their salinity range. Low-salinity (15- $60 \mathrm{ppt}$ ), typically intake water directly from the San Francisco Bay, medium-salinity ponds have 60-180 
ppt salinity and typically concentrate salinity through solar evaporation, and high-salinity ponds have levels over $180 \mathrm{ppt}$. High-salinity ponds are typically red in color, due to green algae (Dunaliella spp.) producing a red pigment at these high salinity levels and salt-resistant bacteria producing a reddish-purplish hue (San Francisco Bay Conservation and Development Commission, 2005). High-salinity ponds typically are the final stage in pond systems that do not have a discharge, or occur naturally in low-lying areas that were flooded with Bay water that slowly evaporated. Each type of pond contributes important habitat for a variety of organisms within the pond complexes.

Low-salinity ponds are most similar to the San Francisco Bay water, and have a high diversity of benthic invertebrates (Courtney \& Clements, 1998; Liang, Shieh, \& Fu, 2002; Lonzarich, 1989; San Francisco Bay Conservation and Development Commission, 2005; Takekawa et al., 2006). Many of the invertebrate species within these ponds are also found in the Bay (San Francisco Bay Conservation and Development Commission, 2005). These species include native and non-native mussels, clams, crabs, sea anemones, worms and salt-tolerant insects (Lonzarich, 1989). Birds associated with low-salinity ponds include white and brown pelicans (Pelecanus occidentalis), double-crested cormorant (Phalacrocorax auritis), snowy egrets (Egretta thula), black-crowned night herons (Nycticorax nycticorax), Forster's terns (Sterna forsteri), sandpipers and avocets, as well as numerous wintering waterfowl (Takekawa, Page, Alexander, \& Becker, 2000). Low-salinity ponds are particularly important to numerous fish-eating birds since these ponds are habitat for many species of fish (San Francisco Bay Conservation and Development Commission, 2005). 
The low-salinity ponds are characterized by shallow, nutrient-rich waters that provide habitat and sustenance to migratory waterbirds and resident species (Thebault, Schraga, Cloern, \& Dunlavey, 2008). The salt ponds contain diverse groupings of invertebrates and algae (Lonzarich \& Smith, 1997) and have become sites of nature reserves and wildlife refuges, such as the Don Edwards Regional Wildlife Refuge, due to their extreme ecological importance (Mejia, Saiki, \& Takekawa, 2008). While restoring some of the former salt ponds to tidal marsh is imperative for tidal marsh species, some salt production ponds should be maintained for their ecological importance in the South Bay region.

The ponds provide habitat, breeding grounds, or food sources for " 70 endangered, rare, and common bird species... and the annual bird use of [the] ponds numbers in the millions" (Thebault et al., 2008, p 841-842; Warnock et al., 2002). The South Bay salt ponds provide habitat for various species of flora and fauna, including $30 \%$ of migratory birds and half of the diving duck populations (Accurso, 1992; Anderson, 1970; Hickey, Warnock, Takekawa, \& Athearn, 2007; Kjelmyr, Page, Shuford, \& Stenzel, 1991; Mejia et al., 2008; Takekawa, Lu, \& Pratt, 2001; United States Department of the Interior, 1995; Warnock et al., 2002). The ponds are particularly important for shorebirds, "birds that run, walk, and wade along the water's edge" (Paulson, 1993); the ponds provide shallow and deep water feeding areas and provide nesting and roosting habitats on the levees and islands (Rintoul, Warnock, \& Page, 2003). 
Benthic invertebrates also are a significant food resource for many fish species that reside in the San Francisco Bay and the South Bay salt ponds. Benthic invertebrates are considered a component of essential fish habitat (Thompson, 2010).

\section{Invertebrates in the South Bay Salt Ponds}

Invertebrates are an extremely vital piece of the food web, providing the sustenance for other invertebrates, fish, shorebirds and waterfowl. Invertebrates provide nutrient cycling in the breakdown of dead material and consumption of algae and plankton (H.T. Harvey \& Associates, 2005). Invertebrates at the South Bay salt ponds belong to different communities based on varying habitats. Benthic invertebrates live within the mud of aquatic ecosystems and are typically sedentary. Epibenthic invertebrates reside on the mud's surface and are typically more mobile. The last invertebrate community is pelagic invertebrates that live in the water column and are highly mobile (H.T. Harvey \& Associates, 2005).

Due to instability from sediment erosion and deposition typically seen in benthic environments in the San Francisco Bay region, most benthic invertebrate communities are dominated by species that are easily adaptable and can colonize quickly, typically non-natives (Nichols, 1979). The South Bay contains a number of introduced species that dominate the benthic system. Since the South Bay experiences a greater stability of salinity and sedimentation (due in part to tidal action in the South Bay), invertebrates tend to have a larger biomass than other areas in the San Francisco or the North Bays (Nichols, 1979; Nichols \& Pamatmat, 1988). 
High biomass invertebrates are the primary food source for migratory and resident birds, contributing to a large portion of the migratory shorebird diet in the South Bay (Davis \& Bidwell, 2008; H.T. Harvey \& Associates, 2005; Reeder, 1951; Rundle, 1982). The abundance and diversity of the invertebrates influences the distribution of the bird species, leading to birds choosing ponds with higher densities of benthics (Colwell and Landrum, 1993; Safran, Isola, Colwell, \& Williams, 1997).

Invertebrate populations fluctuate seasonally in response to water fluctuations, especially salinity (Leland \& Fend, 1998; McRae et al., 1998). Due to the Mediterranean climate of the region (rains beginning around October or November), salt ponds generally are the most saline from summer through the fall. The high salinity of the ponds is due to a decrease in depth through evaporation, decreasing invertebrate biomass and abundance due to high salinity levels (Takekawa et al., 2001). Invertebrates must either be able to withstand these seasonal, sometimes daily changes, or be able to move to regions of preferred salinity (H.T. Harvey \& Associates, 2005). Low salinity levels result in increased invertebrate diversity, decreased density and decreased biomass compared to medium and high salinity levels that result in decreased diversity and increased biomass (Courtney \& Clements, 1998; Liang et al., 2002; Lonzarich, 1989; San Francisco Bay Conservation and Development Commission, 2005; Takekawa et al., 2006). Dissolved oxygen may also contribute to invertebrate biomass; dissolved oxygen is inversely related to salinity and may have a negative effect on invertebrate biomass in highly saline conditions (Takekawa et al., 2006). 
Benthic and epibenthic invertebrates are important water quality indicators for the salt ponds; the invertebrates adapt to changing water quality levels and indicate the livelihood of the ecosystem. These invertebrates are highly abundant, mostly sedentary, and are easily sampled for examination (Dodson, 2001). They provide sustenance for a variety of species, maintain nutrient cycling and decomposition, act as water quality indicators, and provide an avenue for restoration research.

Benthic and epibenthic invertebrates found in the South Bay can be further categorized by functional groups: filter feeders, suspension feeders, and deposit feeders. Filter feeders and suspension feeders feed on similar sources, such as phytoplankton, organic debris and bacteria (H.T. Harvey \& Associates, 2005). Deposit feeders typically obtain food solely from detritus on the surface of the mud (H.T. Harvey \& Associates, 2005). The main food sources for these groups are phytoplankton, diatoms, and bluegreen algae that settle or grow on the mud surface (Meiorin et al., 1991; Nichols \& Pamatmat, 1988). These main food sources are abundant primarily in the spring in the South Bay (Nichols \& Pamatmat, 1988).

Common filter and suspension feeders include shrimp, clams, and mussels, while common deposit feeders include worms, some clams, and crabs (H.T. Harvey \& Associates, 2005). Based on several studies, highly abundant benthic and epibenthic species in the South Bay include bivalve, gastropod, arthropod, and annelid species (Anderson, 1970; Carpelan, 1957). These species are found in the intertidal mudflats and vegetated portions of tidal marshes in the South Bay. 
Bivalves (i.e. clams and mussels) represent the largest invertebrate biomass in the San Francisco Bay (Nichols, 1979). Highly abundant bivalves in the San Francisco Bay Estuary include the gem clam (Gemma gemma), Baltic clam (Macoma petulam), softshelled clam (Mya arenaria), and Asian clam (Corbula amurensis) (Cressey, 1997; Nichols \& Pamatmat, 1988; Nichols \& Thompson, 1985a; Nichols \& Thompson, 1985b; Thompson \& Shouse, 2004). Bivalve species are primarily filter-feeders and rely on large quantities of phytoplankton for food (H.T. Harvey \& Associates, 2005). The distribution of bivalves may also be affected by seasonal variations in the aquatic ecosystems. Thompson (1999) found that bivalves almost completely disappeared from shallow areas in winter and spring, and declined slightly from deeper areas in winter. Thompson also found that recruitment varied from year to year (1991-1995), with areas most affected in shallower waters, possibly due to predation from shorebirds and bat rays. Based on this study, Thompson and Shouse (2004) hypothesized that the recruitment of bivalves in regions where predation occurs is dependent on the presence of adult bivalves and the transportation of bivalve larvae from deeper waters.

Of the abundant bivalves, the Baltic clam is the only native species still common in the South Bay (H.T. Harvey \& Associates, 2005). The Baltic clam contributes significantly to the invertebrate biomass in the South Bay and is eaten by birds (Painter, 1966), bat rays (Thompson \& Shouse, 2004), and a variety of fish species (H.T. Harvey \& Associates, 2005). The Baltic clam can be found in both the intertidal mudflats and in the lower zone of tidal marshes, with the ribbed mussel (Ischadium demissum), where Pacific cordgrass grows (Josselyn, 1983; Niesen \& Lyke, 1981; Vassallo, 1969). 
The most abundant gastropod from prior intertidal mudflat sampling in the San Francisco Bay was the eastern mud snail (Illyanassa obsoleta) (Nichols \& Pamatmat, 1988; Nichols \& Thompson, 1985a; Nichols \& Thompson, 1985b; Thompson \& Shouse, 2004). During sampling of tidal marshes, the eastern mud snail was also present (Niesen \& Lyke, 1981) in the pickleweed marshes, having displaced the native hornsnail (Cerithidea californica) to high salt pans (Race, 1981). In addition, the marsh snails, Assiminea californica and Ovatella myosotis, were found in dense pickleweed marshes (Fowler, 1977).

During invertebrate sampling in the intertidal mudflats of the San Francisco Bay, dominant arthropods included the amphipods Ampelisca abdita, Corophium alienense, Corophium heteroceratum and Grandidierella japonica, the California bay shrimp (Crangon franciscorum) and blacktail bay shrimp (Crangon nigricauda), the cumacean Nippoleucon hinumensis, the yellow shore crab (Hemigrapsus oregonensis), lined shore crab (Pachygrapsus crassipes), Dungeness crab (Cancer magister), brown rock crab (Cancer antennarius), red rock crab (Cancer productus) and the bay barnacle (Balanus improvisus) (Cressey, 1997; Josselyn, 1983; Lowe, Thompson, \& Kellogg, 2000; Nichols \& Pamatmat, 1988; Nichols \& Thompson, 1985a; Nichols \& Thompson, 1985b; Thompson \& Shouse, 2004). Amphipod species found within the pickleweed-dominated tidal marshes of the South Bay include Eogammarus confervicolus, Orchestria traskiana, Hyale plumulosa, and Grandidierella japonica (Josselyn, 1983).

The San Francisco Bay invertebrate sampling showed a high abundance of the polychaete worms Streblospio benedicti, Neanthes succinea, Eteoni lighti, and 
Heteromastus filiformis and the oligochaete worm Tubificidae sp. (Cressey, 1997; Lowe, Thompson, \& Kellogg, 2000; Nichols \& Pamatmat, 1988; Nichols \& Thompson, 1985a; Nichols \& Thompson, 1985b; Thompson \& Shouse, 2004).

A recent study by Cohen and Carlton (2003) compiled information on aquatic invasive species in the San Francisco Bay and found the Bay to be "the most invaded aquatic ecosystem of North America." Studies have been conducted on invasive species and have shown the detrimental effects species cause on the San Francisco Bay, including aggressive predation, abundant filter feeding, and additional competition (Carlton, 1975; Carlton, 1979; Carlton, Thompson, Schemel, \& Nichols, 1990; Hanna, 1966; McGinnis, 1984; Moyle, 1976; Nichols, 1979a; Taylor, 1981).

Since 1850, 212 species have been introduced to the Bay and Delta, $69 \%$ being invertebrates (Cohen \& Carlton, 2003). Most of the introduced invertebrate species are clams, such as Venerupis sp., Musculista sp., and Gemma sp., which were released in ballast water (Cohen \& Carlton, 2003). These introduced clams have become the most abundant bivalves of the South Bay, with the exception of the native Baltic clam (Nichols \& Pamatmat, 1988). Due to the increased filtering ability of these introduced clams, significant impacts to the South Bay's phytoplankton populations have occurred (Cohen \& Carlton, 2003). The most abundant clam in the San Francisco Bay, Corbula amurensis, has shown severe impacts on summer phytoplankton populations (Alpine \& Cloern, 1992). The gem clam occurs in both deep subtidal and high intertidal areas, and can be found in low-salinity salt ponds (H.T. Harvey \& Associates, 2005). In addition, the soft-shell clam was introduced to the region for commercial purposes and still is 
present in the Bay (Skinner, 1962; Thompson \& Shouse, 2004). While the gem clam and soft-shell clam were introduced species, they do provide a food source for shorebirds, waterfowl, and fish (Harvey, Haltiner, \& Williams, 1982; Painter, 1966; Recher, 1966; Thompson, 1999).

The dominant amphipods of the South Bay were also introduced to the region. Ampelisca abdita, Grandidierella japonica, and various Corophium species occur in the salt ponds, but are an important food source for shorebirds on the mudflats (H.T. Harvey \& Associates, 2005). Lastly, the dominant polychaete of the San Francisco Bay, Streblospio benedicti, was first detected in 1932 and has colonized both deep and shallow intertidal habitats (H.T. Harvey \& Associates, 2005).

In low-salinity ponds, numerous annelids, gastropods, and bivalves were sampled during studies by Carpelan (1957) and Anderson (1970). Nematodes were prevalent in mud and decaying material, while the most prevalent polychaete was Polydora ligni/cornuta (Carpelan, 1957). The introduced eastern mud snail was found scattered through the mudflats of low-salinity ponds, along with a variety of other non-arthropod species (Anderson, 1970). In 1989, Lonzarich sampled low- and medium-salinity ponds (pond salinities averaged between 22 and $84 \mathrm{ppt}$ ) and found two gastropods (eastern mud snail and California brackish water snail [Tryonia imitator]), one bivalve (gem clam), two annelids (Nereis succinea and Tubificoides sp.), and six arthropods (Eogammarus confervicolus, Crangon sp., yellow shore crab, Ostracoda sp., Palaemon macrodactylus, and Sphaeroma quoyana) in low-salinity ponds that did not exceed 40 ppt. The ponds that averaged between 22 and 84 ppt were found to contain only the polychaete Polydora 
ligni/cornuta, brine shrimp (Artemia franciscana), acorn barnacle (Balanus sp.), copepods (Copepoda sp.), and amphipods (Corophium sp.) (Lonzarich, 1989).

Takekawa et al. (2004) found that the diversity of invertebrates was highest in low-salinity ponds, compared to medium- and high-salinity ponds. The low-salinity ponds contained 50 to 55 taxa, but were dominated only by three to four taxa that included the polychaete Heteromastus, the gem clam, and the amphipods Corophium and Ericthonius (Takekawa et al., 2004). Mid-salinity ponds contained 25 different taxa, dominated by the polychaetes Polydora sp., Capitella sp., and Streblospio sp., the amphipod Corophium sp., and water boatmen (Trichocorixa sp.) (Takekawa et al., 2004). The high-salinity pond contained 12 taxa and was dominated by brine shrimp and brine flies (Takekawa et al., 2004).

Arthropods and two insect groups are the most ecologically important communities located within the South Bay salt ponds. The brine shrimp are the most abundant invertebrate in medium- to high-salinity ponds, but are absent in ponds with salinities in excess of 200 ppt (Larsson, 2000). Brine shrimp are a large component of the diet of the western sandpiper, Wilson's and red-necked phalaropes (Phalaropus tricolor and Phalaropus lobatus), and other waterbirds, but may not provide a large nutritional value to certain shorebirds (Anderson, 1970; Colwell \& Jehl, 1994; Hamilton, 1975; Harvey, 1988; Harvey et al., 1992; Jehl, 1988; Rubega \& Inouye, 1994). The two insect groups, reticulate water boatmen (Trichocorixa reticulata) and numerous species of brine flies (Ephydra millbrae, Ephydra cinerea, and Lipochaeta slossonae), are highly abundant and provide an important food source for foraging birds in medium- to high- 
salinity ponds (Carpelan, 1957; Maffei, 2000b). The reticulate water boatmen are found year-round in the salt ponds, and can be found in ponds from brackish to $170 \mathrm{ppt}$

(Carpelan, 1957; Cox, 1969; Jang, 1977). The brine flies occur in natural salt pans and ponds, from saline to hypersaline environments (Carpelan, 1957; Maffei, 2000a; Maffei, 2000b).

Table 1. Invertebrates of South Bay salt ponds: Alviso, Eden Landing and Ravenswood complexes. Compiled from Brand et al. (2011), Fulfrost (2010), Takekawa et al. (2005), and Thompson (2010).

\begin{tabular}{|c|c|c|c|c|c|}
\hline \multicolumn{6}{|c|}{ Invertebrates } \\
\hline Annelida & Bivalvia & Gastropoda & Crustacea & Insecta & Other \\
\hline Capitella sp. & Gemma gemma & $\begin{array}{l}\text { Assiminea } \\
\text { californica }\end{array}$ & Ampelisca $\mathrm{sp}$ & Chironomidae & $\begin{array}{l}\text { Turbellaria } \\
\text { sp. }\end{array}$ \\
\hline Cirratulus sp. & $\begin{array}{l}\text { Corbula } \\
\text { amurensis }\end{array}$ & Muricidae & Ampithoidae & Coleoptera & Lineidae \\
\hline Eteone sp. & $\begin{array}{l}\text { Macoma } \\
\text { balthica/petalum }\end{array}$ & Opisthobranchia & Artemia sp. & Corixidae & Nematoda \\
\hline $\begin{array}{l}\text { Heteromastus } \\
\text { sp. }\end{array}$ & $\begin{array}{l}\text { Musculista } \\
\text { senhousia }\end{array}$ & Pyramidellidae & Cirripedia & Diptera & Spider \\
\hline $\begin{array}{l}\text { Neanthes } \\
\text { succinea }\end{array}$ & Mya arenaria & Tryonia sp. & Copepoda & Ephydra sp. & Anthozoa \\
\hline Nereis sp. & Mytilidae & & Corophiidae & Hydrellia & $\begin{array}{l}\text { Diadumene } \\
\text { sp. }\end{array}$ \\
\hline Oligochaeta & $\begin{array}{l}\text { Veneriipes } \\
\text { philippinarium }\end{array}$ & & Cumacea & Hydrophilidae & $\begin{array}{l}\text { Edwardsia } \\
\text { sp. }\end{array}$ \\
\hline Polychaeta & & & $\begin{array}{l}\text { Erichthonius } \\
\text { sp. }\end{array}$ & Muscidae & Hydrozoa \\
\hline Polydora sp. & & & Gammaridae & & $\begin{array}{l}\text { Hydroid } \\
\text { Colony }\end{array}$ \\
\hline Polynoidae & & & $\begin{array}{l}\text { Hemigrapsus } \\
\text { oregonensis }\end{array}$ & & \\
\hline $\begin{array}{l}\text { Pseudopolydora } \\
\text { sp. }\end{array}$ & & & $\begin{array}{l}\text { Melita } \\
\text { californica }\end{array}$ & & \\
\hline $\begin{array}{l}\text { Sabaco } \\
\text { elongates }\end{array}$ & & & Mysis sp. & & \\
\hline Spionidae & & & Ostracoda & & \\
\hline Streblospio sp. & & & $\begin{array}{l}\text { Palaemon } \\
\text { macrodactylus }\end{array}$ & & \\
\hline Tubificoides & & & $\begin{array}{l}\text { Paranthura } \\
\text { elegans }\end{array}$ & & \\
\hline & & & Sphaeromatidae & & \\
\hline
\end{tabular}




\section{Problem Statement}

The relationship between invertebrate abundance and habitat complexity has not previously been studied in the South San Francisco Bay salt ponds. This study assessed benthic invertebrate diversity, richness, and density in response to two types of existing pond structures, islands and wood structures, in two ponds, SF2 and A1. These results provide information on how to increase benthic abundance and diversity in the South Bay ponds to support greater numbers of birds and fish in a smaller pond footprint.

\section{Research Questions}

1. What species are found near islands and wood structures, and in pond bottoms? Which species are most common?

2. How do the two ponds, SF2 and A1, differ from each other?

3. What species are found in each pond (SF2 and A1) in summer and fall?

4. What functional groups are represented by which species?

5. What native and non-native species are found?

6. What are the qualitative characteristics of the ponds?

\section{Hypotheses}

1. There will be no significant relationship between benthic invertebrate parameters and water quality parameters as measured by dissolved oxygen, salinity, temperature, and water depth for each pond. Parameters studied include invertebrate (a) richness, (b) diversity, (c) density and (d) functional group abundance. Functional group abundance include (a) filter feeder, (b) suspension 
feeder, (c) deposit feeder, (d) suspension feeder, (e) benthic invertebrate, and (f) epibenthic invertebrate abundance.

2. In each pond, there will be no significant difference in invertebrate parameters between sites with habitat structures (islands or wood structures) and sites without structures.

3. In each pond, there will be no significant difference in invertebrate parameters before and after migratory bird arrival (summer or fall).

\section{Method}

\section{Study Site}

The South Bay salt ponds are located at the south end of the San Francisco Bay in California, along the Pacific Coast of the United States (Figure 1). Atmospheric temperatures in this region range from an average high of $20^{\circ} \mathrm{C}$ to an average low of $10^{\circ} \mathrm{C}$; temperatures can shift dramatically between the night and day, with nightly drops of $10^{\circ} \mathrm{C}$ in the summer and $8^{\circ} \mathrm{C}$ in the winter (City of San José, 2010).

The South Bay salt ponds are divided into three pond complexes for the South Bay Salt Pond Restoration Project: Eden Landing, Alviso, and Ravenswood (South Bay Salt Pond Restoration Project, 2011). Two ponds were studied--A1 in the Alviso complex and SF2 in the Ravenswood complex (Figure 2). 


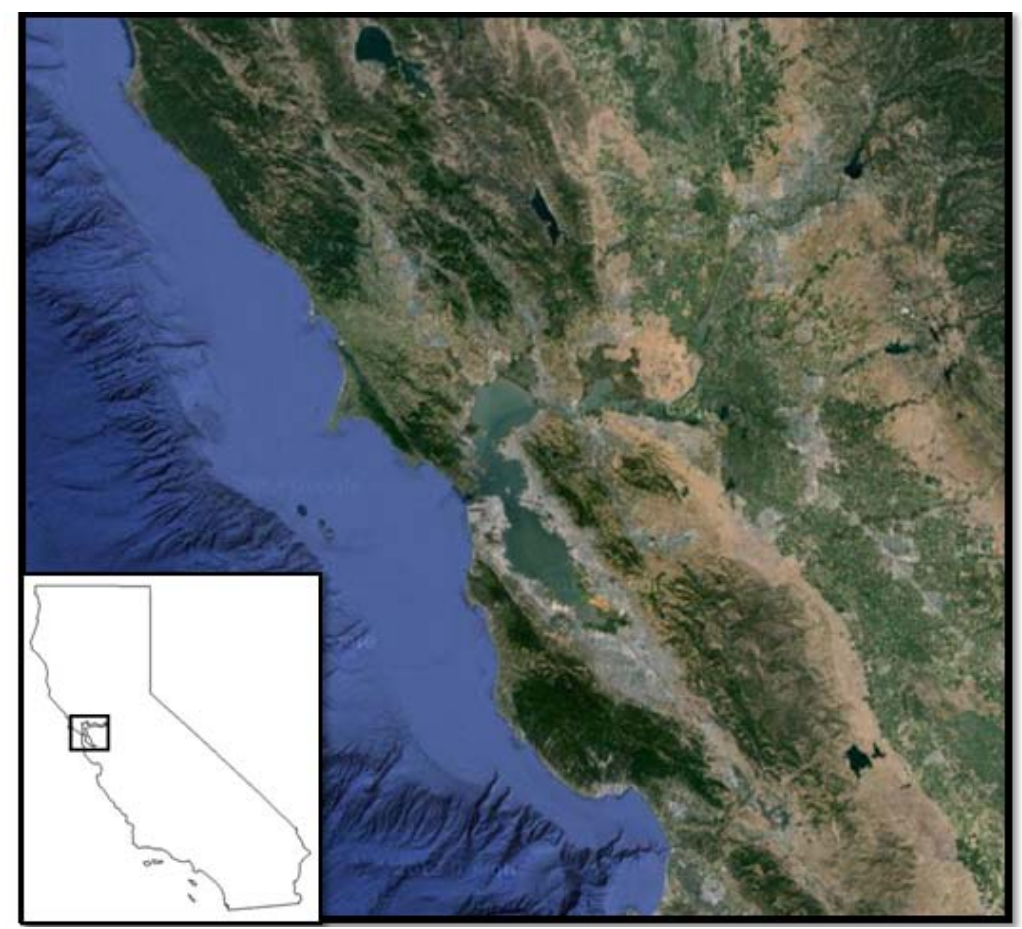

Figure 1. San Francisco Bay Area. Map modified from Google Earth 2013.

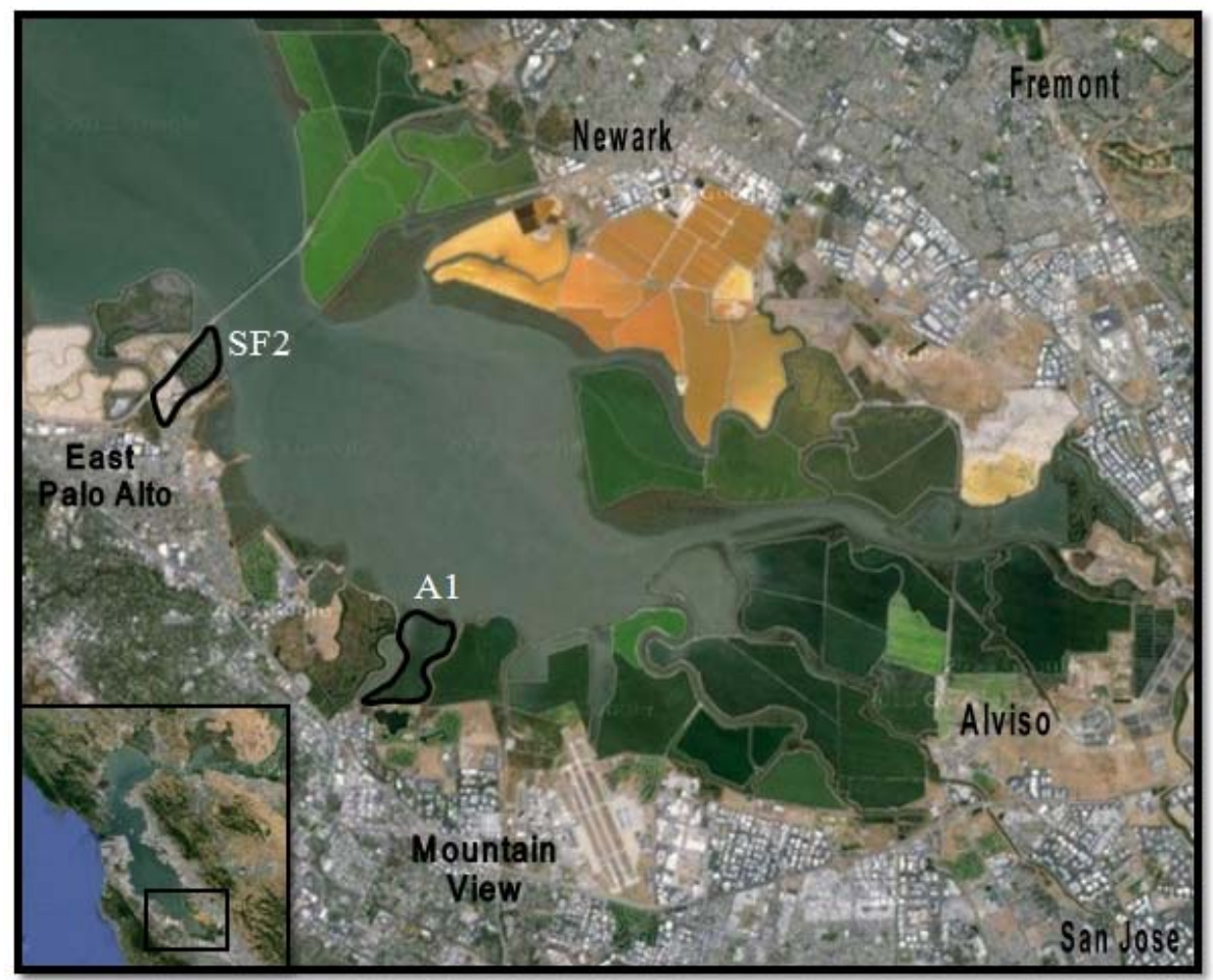

Figure 2. South Bay area with South Bay salt ponds, including SF2 and A1 near East Palo Alto and Mountain View, California. Map modified from Google Earth 2013. 
Pond A1 is located in the Alviso complex near Mountain View, California (21 $\mathrm{km}$ from San José, California and $61 \mathrm{~km}$ from San Francisco, California). The Alviso complex is located at the southern-most portion of the South Bay near the cities of Fremont, Milpitas, San José, Sunnyvale, and Mountain View, California. The complex is owned and operated by United States Fish and Wildlife and is composed of 22 salt ponds ("Progress at the Alviso Ponds," 2013). The restoration of several ponds to tidal habitat began in fall 2010 and created around 133.5 hectares of tidal marsh and tidal channel habitat ("Progress at the Alviso Ponds," 2013). The other ponds, including A1, were managed as ponds during this study.

A1 is a 112 hectare intake pond that typically has an average year-round water depth of $0.5 \mathrm{~m}$ (South Bay Salt Pond Initial Stewardship Plan, 2003). Bay water enters A1 through an intake structure, an existing $1.5 \mathrm{~m}$ gate in the northwestern section of the pond (South Bay Salt Ponds Initial Stewardship Plan, 2003). The outlet structure from A1 is a $1.8 \mathrm{~m}$ siphon that sends pond waters into $\mathrm{A} 2 \mathrm{~W}$, the outlet pond of the two-pond system (South Bay Salt Ponds Initial Stewardship Plan, 2003). Gravity intake flow was determined to be an average of 0.53 cubic $\mathrm{m} / \mathrm{s}$ in the summer and 0.52 cubic $\mathrm{m} / \mathrm{s}$ in the winter (South Bay Salt Ponds Initial Stewardship Plan, 2003). A1 is only marginally influenced by tidal circulation; the flow into the pond is small compared to the volume of the pond and water surface elevation typically only fluctuates by less than $3 \mathrm{~cm}$ (South Bay Salt Ponds Initial Stewardship Plan, 2003). The structures, randomly selected, in A1 include 10 wood structures that were scattered throughout the pond. These wood structures included former duck blinds, fences, and platforms (see example in Figure 3). 
The Ravenswood complex is located on the western edge of the South Bay, on the northern and southern sides of the Dumbarton Bridge near the cities of East Palo Alto and Redwood City, California and comprises six salt ponds, including SF2 which is being restored to create a 62.7 hectare pond with 30 nesting islands for shorebirds and 34.4 hectare area for snowy plover habitat ("Progress at the Ravenswood Ponds," 2013).

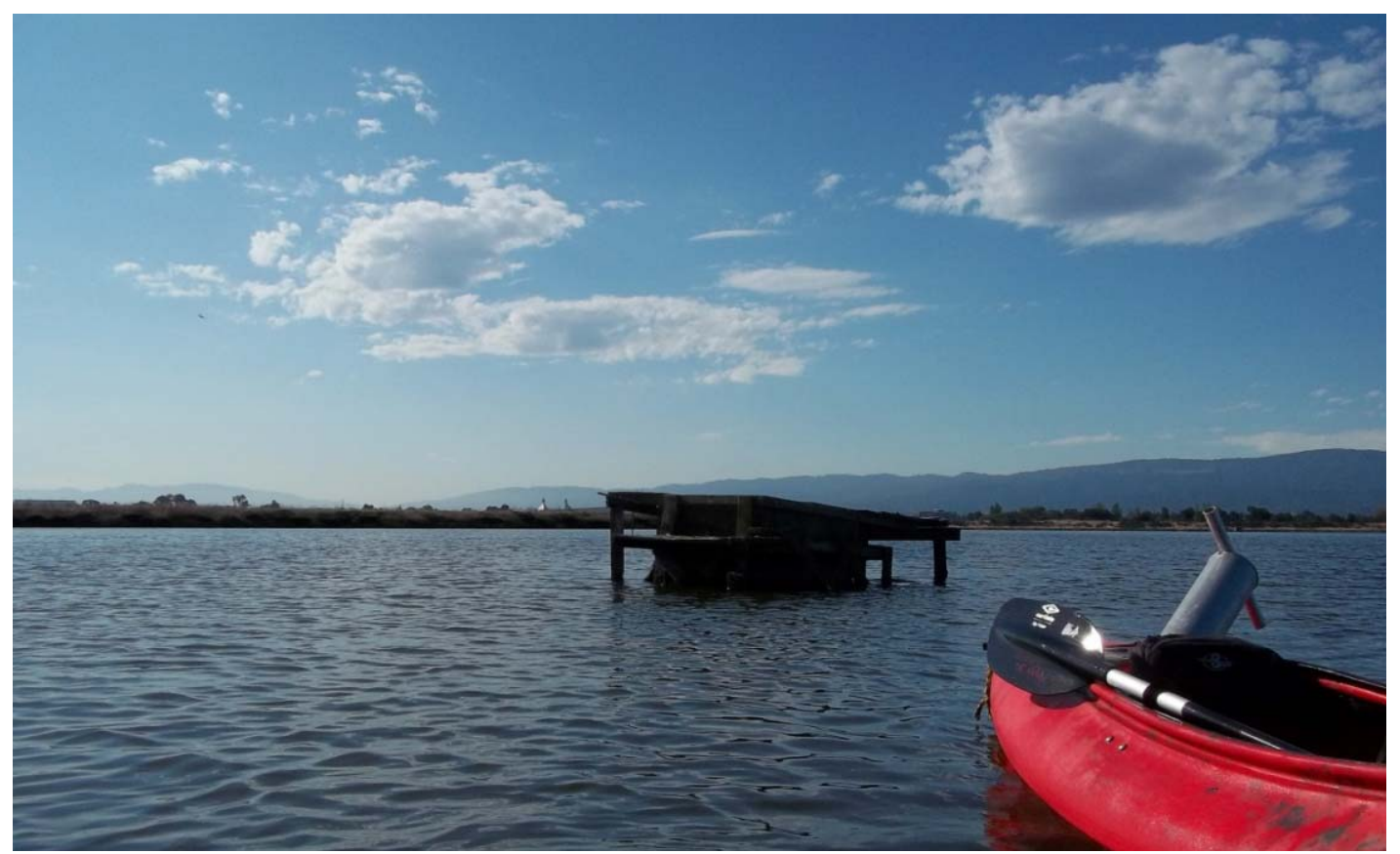

Figure 3. Wood structures in A1. Photo by author, September 2011.

SF2, located just south of the Dumbarton Bridge (Route 84), is a former 97.1 hectare salt pond that was reconfigured, beginning in March 2009, to improve existing flood control levees, construct berms to divide the pond into 62.7 and 34.4 hectare sections, add 30 nesting islands, and install water control structures to regulate water depth and flow rates throughout (Levey, Vasicek, Fricke, Archer, \& Henry, 2010). The 34.4 hectare section was created for snowy plover habitat ("Progress at the Ravenswood Ponds," 2013). The main design for the restoration of the 62.7 hectare managed pond 
habitat consisted of "high-density bird nesting islands interspersed with shallow-water foraging habitat" (Levey et al., 2010, p. 3). The nesting islands were designed to provide nesting for shorebirds and were located away from recreational trails and land-based predator access (Levey et al., 2010).

The nesting islands at SF2 were designed as an experiment to test which shape of nesting island was preferred by birds, round or linear islands. Of the 30 nesting islands, half were round and half were linear (Figure 4). The round islands have a low shoreline edge-to-area ratio, where as the linear islands had a "saw-tooth edge" to have a high shoreline edge-to-area ratio (Moskal, 2013). Channels are present around the bird islands and allow for deeper water to move throughout the pond. Of the seven randomly selected sites for this study, four sites were adjacent to round islands and three sites were adjacent to linear islands.

Pond water enters from the Bay and the salinity is around $30 \mathrm{ppt}$. The pond was designed to maintain shorebird shallow-water feeding areas with depths between 10 and $15 \mathrm{~cm}$ during spring-neap tide cycles and maintain flow through the pond at a rate that provides flushing for bird habitat and water quality goals during spring and summer (Levey et al., 2010; Figure 5). 


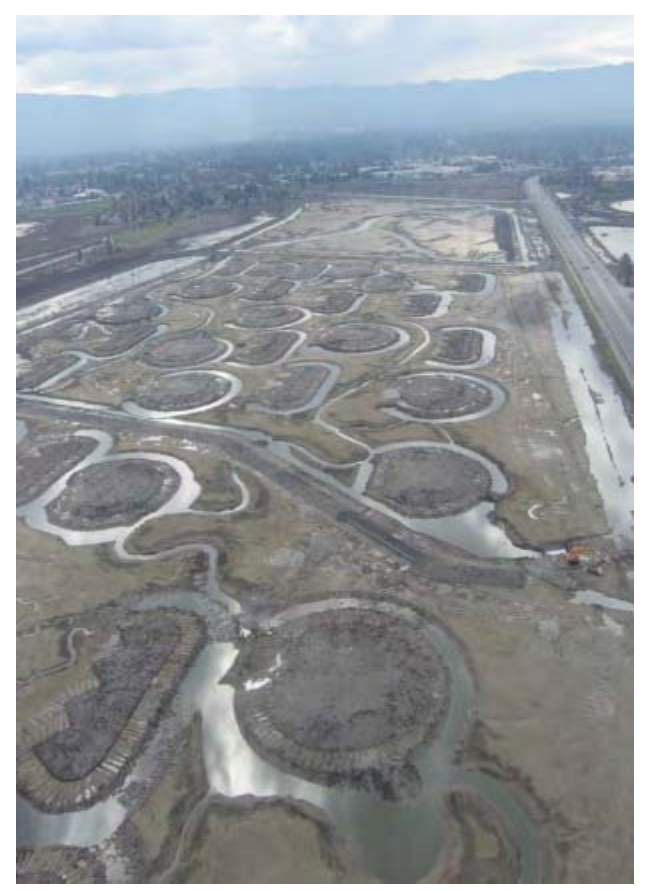

Figure 4. Nesting island design at SF2. Photo by United States Geological Survey (USGS), 2008.

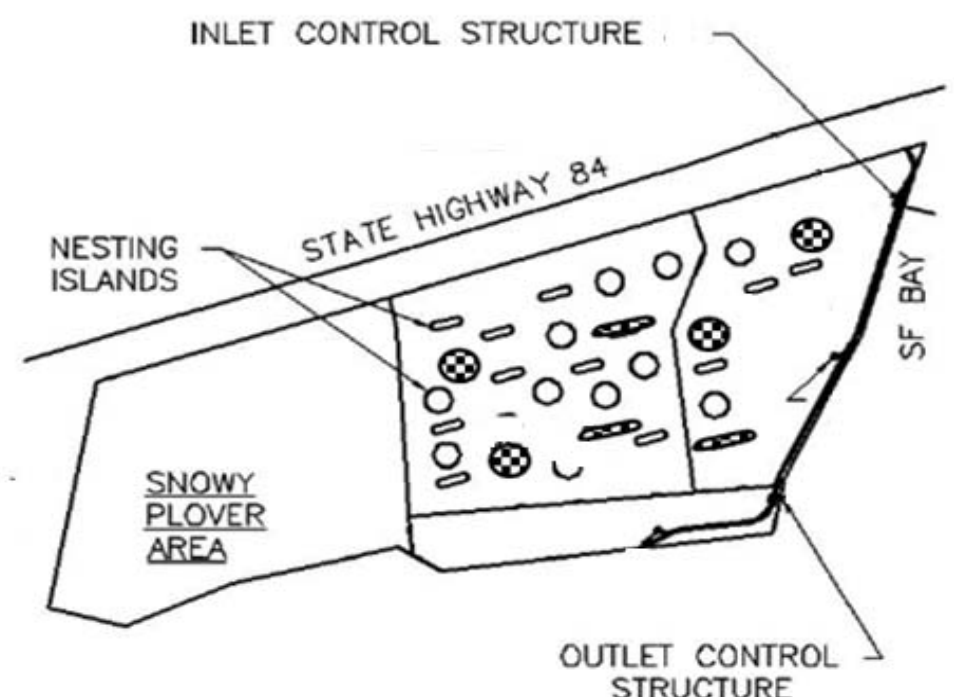

8 Selected Round Island Sites

Selected Linear Island Sites

Figure 5. SF2 Pond Design with locations of seven bird island sampling sites. Modified from Levey et al., 2010. 


\section{Study Design}

Core sampling at structure and non-structure sites was conducted twice, once in summer (June and July) and again in fall (September) 2011. The summer samples were taken soon after shorebirds departed in May for their summer migration. Since birds did not begin returning until September, the mid-September (fall) sampling allowed for invertebrate recolonization prior to shorebird return. In each pond, sediment cores were taken at randomly chosen sites adjacent to structures and paired with randomly chosen control sites, greater than $50 \mathrm{~m}$ from a structure. In SF2, seven paired nesting islands and control sites were sampled for invertebrates on June 18 and 19 and September 17 and 18, 2011. In A1, 10 randomly chosen sites adjacent to existing wood structures and 10 paired randomly chosen control sites were sampled for invertebrates July 2 and 3 and September 24, 2011.

At each sampling site, a total of three cores (subsamples A, B, and C), was taken $10 \mathrm{~m}$ from the structure or the center of the plot for the control sites in both SF2 and A1. Subsampling locations were distributed as evenly as possible around the structure. In addition to invertebrate core samples, water depth and water quality were measured at each sampling site and GPS coordinates were recorded.

Table 2. Study design for ponds SF2 and A1.

\begin{tabular}{|l|l|l|l|}
\hline Ponds & Sample Sites & $\begin{array}{l}\text { Replicates } \text { x Transect } \\
\text { Samples: June/July } \\
\text { 2011 }\end{array}$ & $\begin{array}{l}\text { Replicates x Transect } \\
\text { Samples: September } \\
\mathbf{2 0 1 1}\end{array}$ \\
\hline SF2 & Selected Bird islands & $7 \times 3=21$ (June) & $7 \times 3=21$ \\
\hline SF2 & Control (No structure) & $7 \times 3=21$ (June) & $7 \times 3=21$ \\
\hline A1 & Wood structures & $10 \times 3=30$ (July) & $10 \times 3=30$ \\
\hline A1 & Control (No structure) & $10 \times 3=30($ July) & $10 \times 3=30$ \\
\hline & TOTAL SAMPLES: & June/July 2011: 102 & September 2011: 102 \\
\hline
\end{tabular}


Additional cores were extracted at six randomly selected locations in both SF2 and A1 (three structure and three control sites) in summer 2011 to be analyzed for soil properties. The cores were sent to A\&L Western Agricultural Laboratories, Incorporated in Modesto, California for soil texture and organic matter composition.

\section{Data Collection}

Invertebrate core sampling was conducted according to Anderson and Smith (1999, 2004) and USGS (Brand et al., 2011; Smith, personal communication, 2011; Woo, personal communication, 2011). To assess the benthic invertebrate parameters (diversity, density, richness, and functional group abundance), $10 \mathrm{~cm}$ diameter sediment cores (7.5 cm deep), similar to those used by USGS (2010; Brand et al., 2011 Smith, personal communication, 2011; Woo, personal communication, 2011), were extracted with a Willapa Marine ${ }^{\circledR}$ aluminum clam gun with the help of a field assistant at the randomly selected treatment and control sites in ponds SF2 and A1.

Once collected, invertebrate cores were placed in labeled plastic, zip-lock bags and labeled according to site and transect location. The zipped bags were placed inside a cooler during the remaining sampling. At the end of each day, zipped bags were placed inside a refrigerator until sieving occurred. Half of the pond sites were cored each day, with the sampling of a pond being completed during one weekend in June or July and September 2011. Samples were sieved by elutriation, within seven days of collection, using a $500 \mu \mathrm{m}$ mesh screen. Cores were placed in a clean, five-gallon bucket and gently sprayed with a hose to break apart the core. The turbid water, with debris and invertebrates, was then gently poured over the $500 \mu \mathrm{m}$ mesh sieve. This process was 
continued until the entire core was gently broken up. The debris and invertebrates collected on the sieve were preserved in a 70\% ethanol and Rose Bengal dye solution in $30 \mathrm{~mL}$ sample jars from US Plastics ${ }^{\circledR}$. After preservation, invertebrates were sorted from the sediment and debris using a dissecting microscope into broad taxonomic groups (i.e., Polychaeta, Oligochaeta, Amphipoda, Isopoda, Bivalvia, Gastropoda, Cumacea, Unknown) and placed in $20 \mathrm{~mL}$ glass scintillation vials with 70\% ethanol.

Invertebrates were then identified and counted to lowest possible taxon, typically genus or species, using Carlton (2007), with assistance from San José State lab assistants and interns. All methods, identification, and equations were completed following USGS standards and using equipment provided by USGS, San José State University, and the researcher (Brand et al., 2011; Smith, personal communication, 2011; USGS, 2010).

Additional cores were extracted at six locations in both SF2 and A1 (three structure and three no structure sites) in summer 2011 for soil analysis. For these cores, we followed the same coring procedures for benthic invertebrate collection. The cores were placed in zipped plastic bags and sent to A\&L Western Agricultural Laboratories, Incorporated in Modesto, California, for soil texture and organic matter composition.

An YSI 85 multi-probe water quality mini-sonde was used at each sampling site for water quality parameters. The probe was placed at the bottom of the pond to determine the epibenthic dissolved oxygen, temperature, and salinity. Water quality parameters using the mini-sonde were unavailable for half of pond A1 in July 2011 due to equipment malfunctions. Rough salinity ranges were calculated for this half of the pond in July 2011 by collecting epibenthic water samples using a plastic jar and 
interlocking lid to collect water above the pond benthos. These water samples were collected in labeled zipped plastic bags and later measured using an aquarium hydrometer.

To determine whether water depth affected benthic invertebrate criteria, the depth of the pond was measured by using a meter stick at each sampling location, and the time was recorded.

\section{Data Analysis}

Prior to any data calculations, invertebrate data from each subsample (A, B, and C) at each site were combined into a sum to form a composite data point for the site. Subsamples were assumed to be functionally equivalent and were of equivalent core volume $\left(589.1 \mathrm{~cm}^{3}\right)$. Water quality data for each subsample site was averaged to determine water quality data for the site location.

Species richness was calculated by determining the number of morphospecies found at site. Diversity was calculated using the Shannon-Weiner Index (Shannon \& Weaver, 1949) through calculating $\mathrm{H}^{\prime}$ for each sampling site. After calculating the Shannon-Weiner diversity, Shannon's equitability $\left(E_{H}\right)$, or evenness, was calculated to determine how evenly the diversity was distributed (Lloyd \& Ghelardi, 1964; Peet,

1974). $E_{H}$ was calculated using $\frac{H^{\prime}}{H_{\text {max }}^{\prime}}$, where $H_{\text {max }}^{\prime}=\ln (\mathrm{S}), \mathrm{S}$ equals species richness. Invertebrate density was calculated by dividing the invertebrate abundances by the number of subsamples to determine the number of individuals that were located in the core volume. 
Inferential statistics were calculated using SYSTAT12 ${ }^{\mathrm{TM}}$. Tests were separated by pond, as the two ponds and types of structures were very different from each other. Prior to conducting any statistical tests, all benthic and water quality parameters were tested for homogeneity of variances and normality. Any data that did not meet normality or homogeneity of variances were log-transformed.

Water quality parameters were initially assessed for correlation with each other. Once critical coefficients were determined by the Spearman rank correlation, a Spearman table (Appendix E) was used to evaluate critical coefficient significance. In regards to my first hypothesis about water quality parameters and benthic parameters, a Spearman rank correlation or regression analysis was performed depending on results of parametric testing (Table 3). Water quality parameters that were found to be significantly correlated with benthic parameters were included in further tests as needed.

Table 3. Regression and Spearman rank correlation variables.

\begin{tabular}{|c|c|c|}
\hline Hypothesis & Independent Variable & Dependent Variables (Parametric/Non-Parametric) \\
\hline $\begin{array}{c}\text { 1. Benthic } \\
\text { invertebrate } \\
\text { parameters and water } \\
\text { quality parameters are } \\
\text { not related. }\end{array}$ & $\begin{array}{c}\text { Log Dissolved Oxygen, } \\
\text { Log Salinity, } \\
\text { Temperature, Log } \\
\text { Water Depth }\end{array}$ & $\frac{\text { Parametric: Richness, Diversity, Density, Benthic }}{\text { Non-Parametric: Deposit, Filter, Suspension, }}$ \\
\hline
\end{tabular}

To test whether benthic parameters were affected by structure or season, two-way Analysis of Covariance (ANCOVA) or two-way Analysis of Variance (ANOVA), and Kruskal-Wallis tests were conducted depending on whether variables met parametric assumptions. Significantly correlated water quality variables were included as covariates in the ANCOVA. Species richness, diversity, density, and the benthic functional group 
data for each pond were tested with a two-way ANCOVA (or two-way ANOVA if the covariate was excluded) having two levels of season (summer, fall) and type of structure (structure, no structure), with temperature as a covariate (Table 4). Epibenthic, deposit, filter, suspension, and predatory feeder functional group data for each pond were subjected to a one-way Kruskal-Wallis test for type of structure (structure, no structure) and again for season (summer or fall).

Table 4. ANCOVA, ANOVA, and Kruskal-Wallis variables.

\begin{tabular}{|c|c|c|}
\hline Hypothesis & $\begin{array}{c}\text { Independent Variable } \\
\text { (Covariate) }\end{array}$ & Dependent Variables (Parametric/Non-Parametric) \\
\hline $\begin{array}{c}\text { 2. Benthic parameters } \\
\text { and structures are not } \\
\text { related. }\end{array}$ & $\begin{array}{c}\text { Structure or Control } \\
\text { (Temperature) }\end{array}$ & $\frac{\text { Parametric: Richness, Diversity, Density, Benthic }}{\frac{\text { Non-Parametric: Deposit, Filter, Suspension, }}{\text { Predatory, Epibenthic }}}$ \\
\hline $\begin{array}{c}\text { 3. Benthic parameters } \\
\text { and the arrival or } \\
\text { departure of migratory } \\
\text { birds are not related. }\end{array}$ & $\begin{array}{c}\text { Summer or Fall } \\
\text { (Temperature) }\end{array}$ & $\frac{\text { Parametric: Richness, Diversity, Density, Benthic }}{\text { Non-Parametric: Deposit, Filter, Suspension, }}$ \\
\hline
\end{tabular}

\section{Results}

\section{Qualitative Pond Characteristics}

During sampling, notations were made regarding qualitative pond characteristics (Table 5). These characteristics were in regards to soil color, texture, composition, odors, debris, and any birds or fish observed while sampling.

\section{Soil Analysis}

SF2 was characterized as having clay soils, with a medium to high level of organic matter within the soils (Table 6). Soil conditions did not appear to change based on the presence of bird islands. A1 had an even split of clay and clay-loam soils, with a higher percentage of sand than SF2 sites (Table 6). The organic matter in the soil was in 
the high to very-high levels and also did not appear to change based on the presence of wood structures.

Table 5. Qualitative characteristics of SF2 and A1 in summer and fall.

\begin{tabular}{|l|l|l|l|}
\hline \multicolumn{2}{|l|}{} & \multicolumn{1}{c|}{ SF2 } & \multicolumn{1}{c|}{ A1 } \\
\hline \multirow{4}{*}{ Summer } & Soil & $\begin{array}{l}\text { Light to dark gray, } \\
\text { firm, difficult to sieve }\end{array}$ & $\begin{array}{l}\text { Dark brown, } \\
\text { loose/watery }\end{array}$ \\
\cline { 2 - 4 } & Debris & $\begin{array}{l}\text { Rocks, salt crystals, } \\
\text { woody debris }\end{array}$ & $\begin{array}{l}\text { Woody debris, shell } \\
\text { fragments }\end{array}$ \\
\cline { 2 - 4 } & Birds and Fish & $\begin{array}{l}\text { Avocets and black- } \\
\text { necked stilts }\end{array}$ & Cormorants \\
\hline \multirow{4}{*}{ Fall } & Soil & $\begin{array}{l}\text { Light to dark gray, } \\
\text { firm, difficult to sieve }\end{array}$ & $\begin{array}{l}\text { Black, loose/watery, } \\
\text { hydrogen sulfide } \\
\text { smell }\end{array}$ \\
\cline { 2 - 4 } & Debris & Rocks, salt crystals & $\begin{array}{l}\text { Woody debris, shell } \\
\text { fragments }\end{array}$ \\
\cline { 2 - 5 } & Birds and Fish & $\begin{array}{l}\text { Common egrets and } \\
\text { white pelicans; } \\
\text { rainwater killifish and } \\
\text { arrow goby }\end{array}$ & $\begin{array}{l}\text { Black-necked stilts, } \\
\text { gulls, brown pelicans; } \\
\text { rainwater killifish }\end{array}$ \\
\hline
\end{tabular}

Table 6. Soil properties for SF2 and A1 (A\&L Western Agricultural Laboratories, Incorporated 2011).

\begin{tabular}{|c|c|c|c|c|c|c|c|}
\hline & $\begin{array}{c}\text { Structure } \\
\text { Pond }\end{array}$ & \multicolumn{4}{|c|}{ Particle Size Analysis } & \multicolumn{2}{c|}{ Organic Matter } \\
\cline { 3 - 8 } & $\begin{array}{c}\text { Structure } \\
\text { (NS) }\end{array}$ & $\begin{array}{c}\text { Sand } \\
\%\end{array}$ & $\begin{array}{c}\text { Silt } \\
\%\end{array}$ & $\begin{array}{c}\text { Clay } \\
\%\end{array}$ & $\begin{array}{c}\text { Soil } \\
\text { Texture* }\end{array}$ & \% Rating** & ENR** \\
\hline SF2 & NS & 34 & 20 & 45 & C & $5.2 \mathrm{H}$ & 134 \\
\hline SF2 & NS & 10 & 30 & 59 & C & $3.3 \mathrm{M}$ & 96 \\
\hline SF2 & NS & 14 & 32 & 53 & C & $3.2 \mathrm{M}$ & 94 \\
\hline SF2 & S & 32 & 18 & 49 & C & $5.4 \mathrm{VH}$ & 138 \\
\hline SF2 & S & 16 & 28 & 55 & C & $3.7 \mathrm{M}$ & 104 \\
\hline SF2 & S & 16 & 34 & 49 & C & $4.6 \mathrm{H}$ & 122 \\
\hline A1 & NS & 39 & 21 & 40 & C & $5.6 \mathrm{VH}$ & 142 \\
\hline A1 & NS & 44 & 19 & 36 & CL & $6.3 \mathrm{VH}$ & 156 \\
\hline A1 & NS & 32 & 24 & 43 & C & $5.1 \mathrm{H}$ & 132 \\
\hline A1 & S & 24 & 26 & 39 & CL & $4.3 \mathrm{H}$ & 116 \\
\hline A1 & S & 36 & 20 & 43 & C & $3.9 \mathrm{H}$ & 108 \\
\hline A1 & S & 44 & 17 & 39 & CL & $7.5 \mathrm{VH}$ & 180 \\
\hline
\end{tabular}

*Code to Soil Texture: Sand (S), Silt (ST), Clay (C), Sand Loam (SL), Silt Loam (STL), Clay Loam (CL) **Code to Rating: Very Low (VL), Low (L), Medium (M), High (H), and Very High (VH)

***ENR - Estimated Nitrogen Release, pounds per acre 


\section{Water Quality}

Water quality parameters varied widely within SF2 and A1, with variations possibly occurring due to flow, tidal influence, time of day, or water depth (Table 7).

Structure sites and no structure sites were combined due to no significant difference between water quality results of structure and no structure sites.

Table 7. Water quality results for SF2 and A1 in summer and fall.

\begin{tabular}{|c|ccc|ccc|ccc|ccc|}
\hline \multirow{2}{*}{$\begin{array}{c}\text { Pond } \\
\text { Season }\end{array}$} & \multicolumn{3}{|c|}{$\begin{array}{c}\text { Dissolved } \\
\text { Oxygen, } \\
\text { mg/L }\end{array}$} & \multicolumn{3}{|c|}{$\begin{array}{c}\text { Salinity, } \\
\text { ppt }\end{array}$} & \multicolumn{3}{c|}{$\begin{array}{c}\text { Temperature, } \\
{ }^{\circ} \mathbf{C}\end{array}$} & \multicolumn{3}{c|}{$\begin{array}{c}\text { Depth, } \\
\text { cm }\end{array}$} \\
\cline { 2 - 12 } & Min & Max & Mean & Min & Max & Mean & Min & Max & Mean & Min & Max & Mean \\
\hline $\begin{array}{c}\text { SF2 } \\
\text { Summer }\end{array}$ & 4.2 & 14.9 & 9.2 & 14.6 & 22.8 & 21.6 & 17.9 & 25.1 & 21.7 & 12.7 & 33.0 & 22.8 \\
\hline $\begin{array}{c}\text { SF2 } \\
\text { Fall }\end{array}$ & 2.1 & 5.0 & 3.6 & 26.5 & 28.5 & 27.4 & 16.7 & 22.0 & 18.5 & 10.6 & 34.7 & 20.3 \\
\hline $\begin{array}{c}\text { A1 } \\
\text { Summer }\end{array}$ & 1.6 & 8.5 & 6.1 & 18.3 & 24.5 & 20.0 & 20.4 & 23.3 & 21.6 & 32.2 & 59.3 & 49.7 \\
\hline $\begin{array}{c}\text { A1 } \\
\text { Fall }\end{array}$ & 1.2 & 4.4 & 2.3 & 22.2 & 27.4 & 24.9 & 19.9 & 24.7 & 22.5 & 25.0 & 57.0 & 43.1 \\
\hline
\end{tabular}

During summer sampling in SF2, benthic temperatures ranged from 17.9 to 25.1 ${ }^{\circ} \mathrm{C}$, salinity ranges were between 14.6 and $22.8 \mathrm{ppt}$, and dissolved oxygen ranged from 4.2 to $14.9 \mathrm{mg} / \mathrm{L}$. Water depth ranged in the pond varied between $12.7 \mathrm{~cm}$ and $33.0 \mathrm{~cm}$ deep. Water quality results within SF2 in fall followed similar patterns, but showed increased salinity ranges, decreased dissolved oxygen ranges, and decreased temperature ranges compared to summer (Figure 6).

Parameters in A1 also showed variation in the ranges throughout the pond, but during the summer sampling only one half of the pond (11 sites) was measured due to malfunctions in the mini-sonde. In A1, the temperature of the 11 measured sites ranged from 20.4 to $23.3^{\circ} \mathrm{C}$, salinity ranges (including the nine sites estimated using a 
hydrometer) were between 18.3 and $24.5 \mathrm{ppt}$, and dissolved oxygen range was 1.6 to 8.5 $\mathrm{mg} / \mathrm{L}$. The water depth ranged from 32.2 to $59.3 \mathrm{~cm}$ deep. During the fall sampling in A1, all sites were able to be measured using the mini-sonde. The salinity increased, dissolved oxygen decreased, and temperature decreased compared to the summer samplings (Figure 6).

Mean water quality data for A1 and SF2 in summer and fall is shown in Figure 6. For both SF2 and A1, the mean dissolved oxygen decreased, mean salinity increased, and mean depth decreased from summer to fall (Figure 6). Mean water quality parameters were not significantly different between ponds, with the exception of mean water depth, which was deeper in A1 than in SF2.

In SF2, temperature was significantly positively correlated with dissolved oxygen (Spearman rank; $\rho[28]=0.83, p<0.001$ ) and negatively correlated with salinity (Spearman rank; $\rho[28]=-0.36, p=0.05$ ), but temperature was not significantly correlated with water depth. Salinity also correlated negatively with dissolved oxygen (Spearman rank; $\rho[31]=-0.62, p<0.001)$.

In $\mathrm{A} 1$, in contrast, temperature correlated positively with salinity (Spearman rank; $\rho[31]=0.68, p<0.001)$, but temperature was not significantly correlated with dissolved oxygen or water depth. Salinity again correlated negatively with dissolved oxygen (Spearman rank; $\rho[31]=-0.54, p<0.001$ ), however. These results and the literature support the correlation of temperature and other water quality variables. 


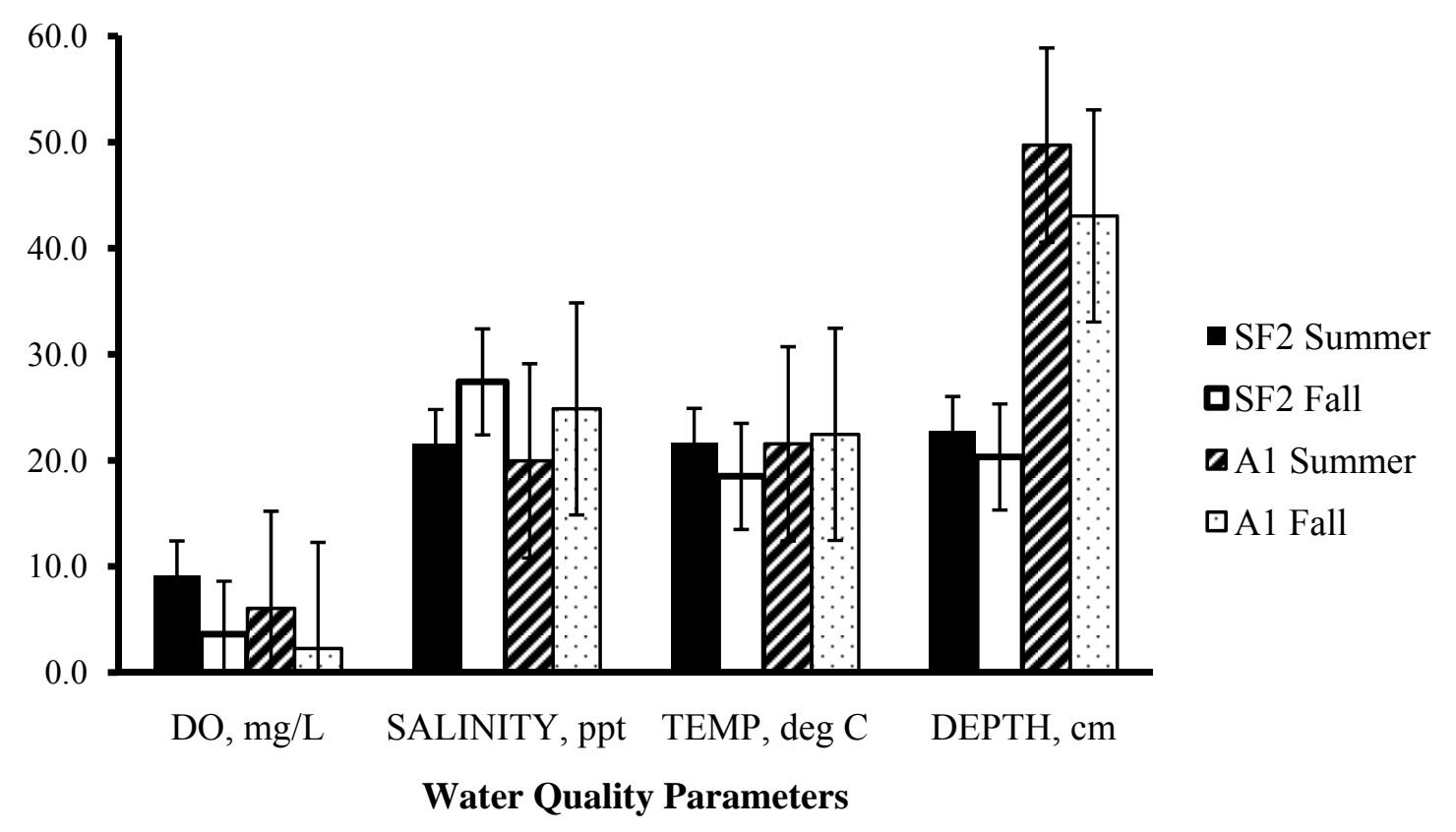

Figure 6. Mean $( \pm \mathrm{SE})$ water quality data for SF2 and A1 in summer and fall.

\section{Invertebrate Species}

A total of 10,514 individuals were collected from all 34 sites in both ponds during both seasons, comprising 44 different morphospecies in benthic and epibenthic functional groups (Appendix A-D). The most abundant species collected were the bivalve Gemma gemma $(n=2,358)$, annelids in the class Oligochaeta $(n=1,950)$, polychaetes in the family Capitellidae $(n=1,815)$, and the cumacean Nippoleucon hinumensis $(n=1,424)$. The total individuals for SF2 and A1 for each season are shown in Figure 7. Common invertebrate species for each pond and sampling season are shown in Table 8. 


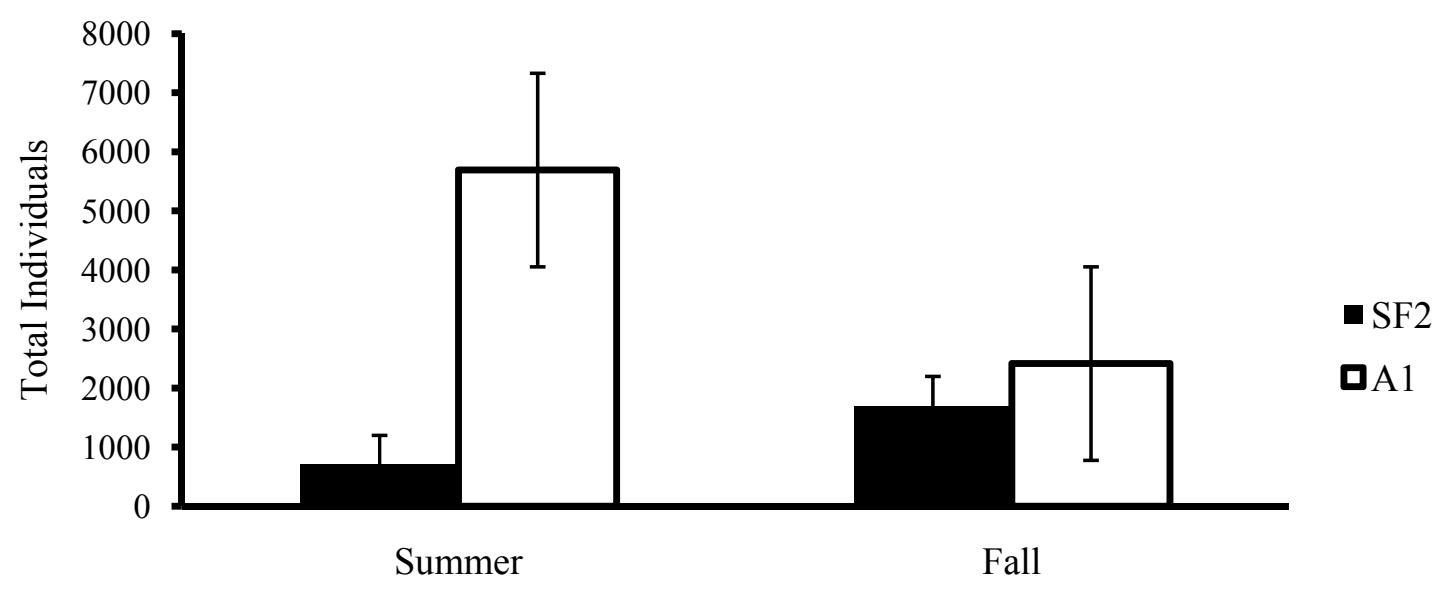

Season

Figure 7. Total individuals for SF2 and A1 in summer and fall. Error bars represent standard error.

Table 8. Common invertebrates $(n>10)$ for each pond during each sampling season.

\begin{tabular}{|c|c|c|c|c|}
\hline \multirow{2}{*}{$\begin{array}{c}\text { Common Invertebrates } \\
(>10 \text { individuals })\end{array}$} & \multicolumn{2}{|c|}{ SF2 } & \multicolumn{2}{|c|}{$\mathrm{A} 1$} \\
\hline & June & Sept & July & Sept \\
\hline \multicolumn{5}{|l|}{ Annelida } \\
\hline Capitellidae & & $\mathrm{X}$ & $\mathrm{X}$ & $\mathrm{X}$ \\
\hline Eteone sp & $\mathrm{X}$ & $\mathrm{X}$ & $\mathrm{X}$ & $\mathrm{X}$ \\
\hline Nereis sp & $\mathrm{X}$ & $\mathrm{X}$ & & \\
\hline Oligochaeta & & $\mathrm{X}$ & $\mathrm{X}$ & $\mathrm{X}$ \\
\hline Polydora sp & & $\mathrm{X}$ & & \\
\hline Spionidae & $\mathrm{X}$ & $\mathrm{X}$ & $\mathrm{X}$ & $\mathrm{X}$ \\
\hline \multicolumn{5}{|l|}{ Bivalvia } \\
\hline Corbula amurensis & & $\mathrm{X}$ & & \\
\hline Gemma gemma & & & $\mathrm{X}$ & $\mathrm{X}$ \\
\hline Macoma petalum & & $\mathrm{X}$ & & \\
\hline Mya arenaria & $\mathrm{X}$ & $\mathrm{X}$ & & \\
\hline \multicolumn{5}{|l|}{ Crustacea } \\
\hline Ampelisca abdita & & & $\mathrm{X}$ & \\
\hline Ampithoe valida & $\mathrm{X}$ & & $\mathrm{X}$ & $\mathrm{X}$ \\
\hline Corophiidae & $\mathrm{X}$ & $\mathrm{X}$ & & \\
\hline Eogammarus confervicolus & $\mathrm{X}$ & $\mathrm{X}$ & & \\
\hline Grandidierella japonica & $\mathrm{X}$ & $\mathrm{X}$ & $\bar{X}$ & $\mathrm{X}$ \\
\hline Nippoleucon hinumensis & $\mathrm{X}$ & $\mathrm{X}$ & $\mathrm{X}$ & $\mathrm{X}$ \\
\hline Podocopa & & & & $\mathrm{X}$ \\
\hline \multicolumn{5}{|l|}{ Gastropoda } \\
\hline Opisthobranchia & & $\mathrm{X}$ & $\mathrm{X}$ & $\mathrm{X}$ \\
\hline \multicolumn{5}{|l|}{ Insecta Larvae } \\
\hline Paraclunio alaskensis & $X$ & & & \\
\hline
\end{tabular}


The summer sampling in SF2 produced 21 morphospecies. The five most abundant taxa, comprising $98 \%$ of the 704 individuals collected, were cumaceans $(38 \%)$, amphipods (34\%), polychaetes (13\%), insect larvae (8\%), and bivalves (5\%). The most abundant species collected was $N$. hinumensis $(n=270)$, followed by the amphipod family Corophiidae $(n=131)$, and the polychaete Nereis procera $(n=46)$. The average evenness of species diversity for summer was $79 \%$ of the maximum potential species diversity.

Fall sampling in SF2 resulted in 25 morphospecies at the 14 sampling sites and 1,701 individuals were collected. The four most abundant taxa comprised $95 \%$ of the invertebrate abundance. Polychaetes comprised 55\%, amphipods 35\%, bivalves 3\%, and gastropods $2 \%$. The most abundant taxa were Capitellidae $(n=682)$, Corophiidae $(n=$ 388), the polychaete family Spionidae $(n=176)$, and the amphipod Grandidierella japonica $(n=172)$. The average evenness of species diversity for fall was $60 \%$ of the maximum potential species diversity. Invertebrate diversities for SF2 for summer and fall samplings are shown in Figures 8-10.
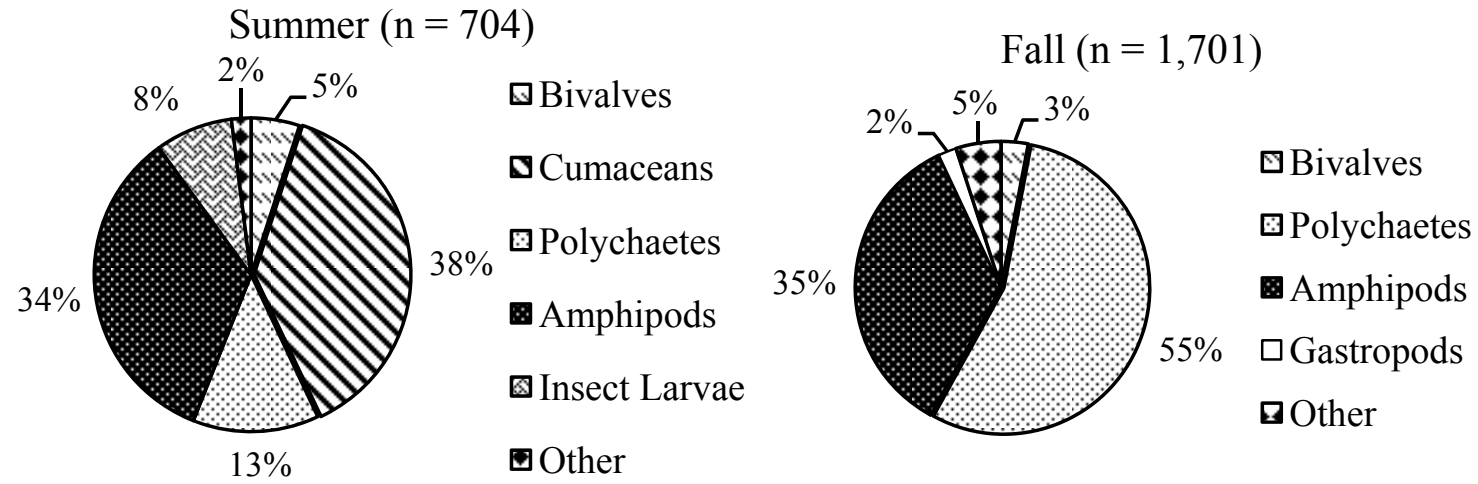

Figure 8. SF2 broad invertebrate taxa diversity for summer and fall. 

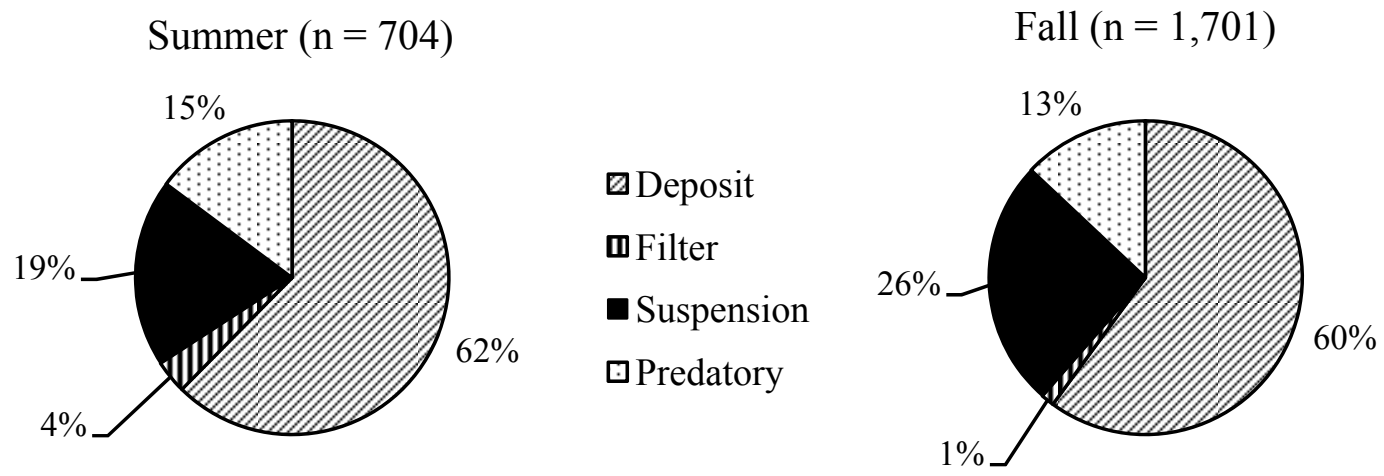

Figure 9. SF2 invertebrate feeding group diversity for summer and fall.

Summer $(n=704)$

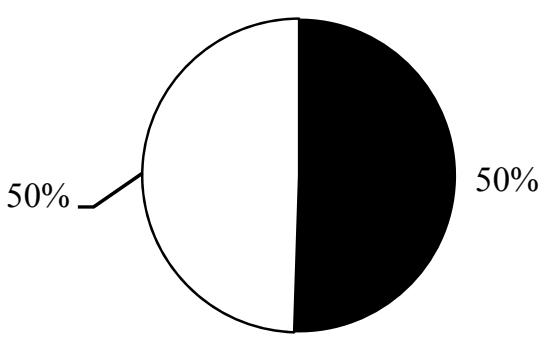

๑Deposit

mFilter

- Suspension

๑Predatory
Fall $(\mathrm{n}=1,701)$

- Benthic

$\square$ Epibenthic

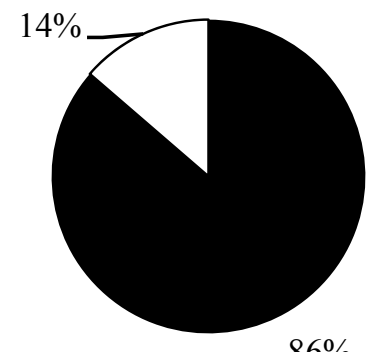

Figure 10. SF2 invertebrate habitat group diversity for summer and fall.

A total of 5,693 individuals were collected during summer sampling in A1, composed of 22 morphospecies. The six most abundant taxa comprised over $99 \%$ of the invertebrate abundance. Bivalves comprised $41 \%$, cumaceans $20 \%$, oligochaetes $18 \%$, polychaetes $15 \%$, amphipods $3 \%$, and gastropods $3 \%$. The most abundant taxa collected were G. gemma $(n=2,295), N$. hinumensis $(n=1,119)$, and Oligochaeta $(n=1,036)$. The average evenness of species diversity for summer was $65 \%$ of the maximum potential species diversity.

For fall sampling in A1, 26 morphospecies were identified at the 20 sites. The five most abundant taxa comprised $95 \%$ of the invertebrate abundance. Polychaetes comprised $50 \%$, oligochaetes $36 \%$, gastropods $6 \%$, and bivalves $3 \%$. A total of 2,416 
individuals were collected, with the most abundant taxa collected being Capitellidae $(n=$ 907), followed by Oligochaeta $(n=863)$, and Spionidae $(n=278)$. The average evenness of species diversity for fall was $65 \%$ of the maximum potential species diversity. Invertebrate diversity for A1 for summer and fall sampling is shown in Figures 11-13.

The results of regression analysis of parametric water quality parameters are seen in Table 9. Temperature was significantly correlated with species richness in A1 ( $p=$ $0.01)$, density in SF2 $(p<0.001)$ and A1 $(p=0.002)$, and benthic individuals in SF2 $(p<$ $0.001)$ and $\mathrm{A} 1(p=0.001)$.

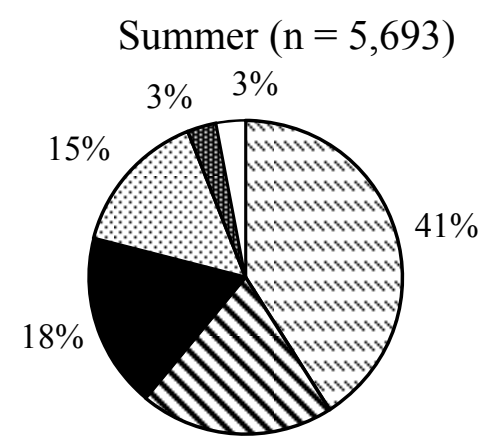

$20 \%$
Fall $(\mathrm{n}=2,416)$

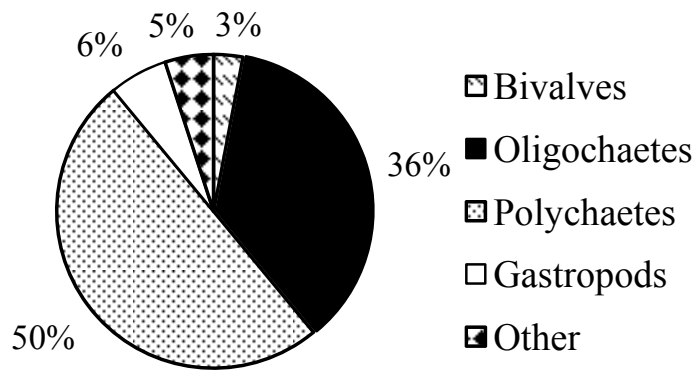

Figure 11. Broad invertebrate taxa diversity in pond A1 for summer and fall.
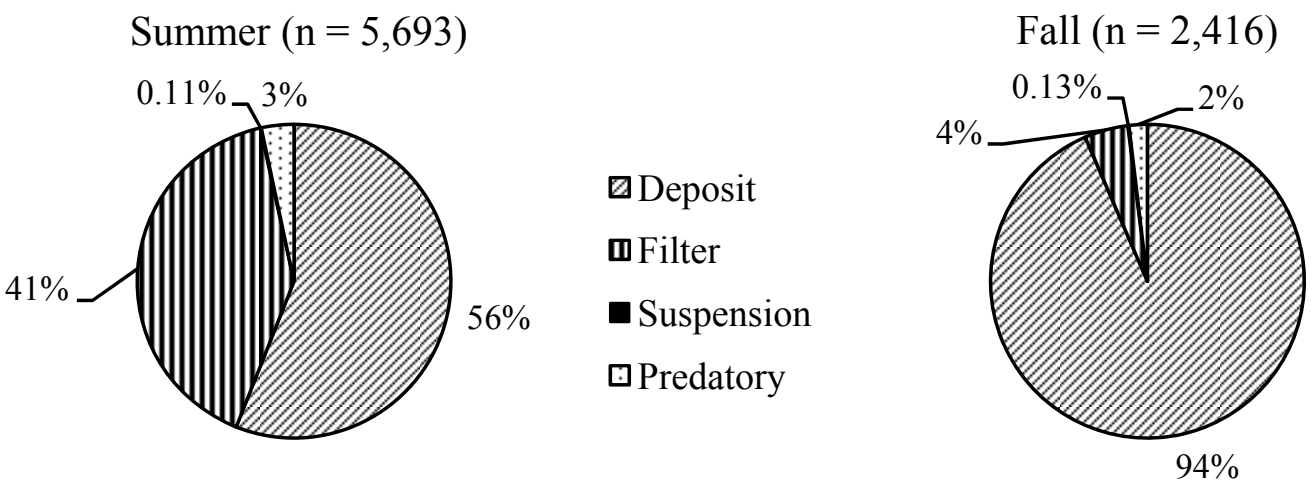

Figure 12. Invertebrate feeding group diversity in pond A1 for summer and fall. 
Summer $(\mathrm{n}=5,693)$

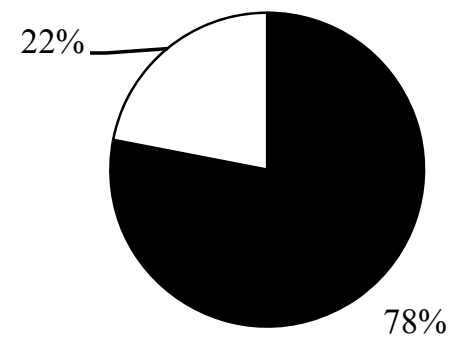

Fall $(\mathrm{n}=2,416)$

- Benthic

$\square$ Epibenthic

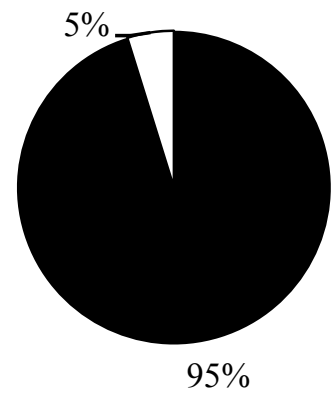

Figure 13. A1 invertebrate habitat group diversity for summer and fall.

Table 9. Regression results of parametric water quality parameters on benthic invertebrate criteria. All $p$-values $<0.05$ considered significant.

\begin{tabular}{|c|c|c|}
\hline \multirow{2}{*}{$\begin{array}{l}\text { Dependent } \\
\text { Variable }\end{array}$} & \multicolumn{2}{|c|}{ Results } \\
\hline & SF2 & A1 \\
\hline Species Richness & $\begin{array}{l}\text { Temp: } \\
b=-0.30, t(28)=-1.55, p=0.14 \\
\text { Depth: } \\
b=-0.02, t(28)=-0.10, p=0.92\end{array}$ & $\begin{array}{l}\text { Temp: } \\
b=-0.48, t(31)=-2.92, p=0.01\end{array}$ \\
\hline Diversity & $\begin{array}{l}\frac{\text { Temp: }}{b=0.25, t}, t(28)=1.33, p=0.20 \\
\text { Depth: } \\
b=0.24, t(28)=1.25, p=0.22\end{array}$ & $\begin{array}{l}\text { Temp: } \\
b=-0.08, t(31)=-0.48, p=0.64\end{array}$ \\
\hline Density & $\begin{array}{l}\text { Temp: } \\
\boldsymbol{b}=\mathbf{- 0 . 6 8}, \boldsymbol{t}(\mathbf{2 8})=-\mathbf{4 . 7 4}, \boldsymbol{p}<\mathbf{0 . 0 0 1} \\
\text { Depth: } \\
b=-0.14, t(28)=-1.00, p=0.33\end{array}$ & $\begin{array}{l}\text { Temp: } \\
b=-0.54, t(31)=-3.46, p=0.002\end{array}$ \\
\hline Log Benthic & $\begin{array}{l}\text { Temp: } \\
\boldsymbol{b}=\mathbf{- 0 . 7 1}, \boldsymbol{t}(\mathbf{2 8})=\mathbf{- 5 . 0 9}, \boldsymbol{p}<\mathbf{0 . 0 0 1} \\
\underline{\text { Depth: }} \\
b=-0.10, t(28)=-0.70, p=0.49\end{array}$ & $\begin{array}{l}\text { Temp: } \\
b=-0.56, t(31)=-3.67, p=0.001\end{array}$ \\
\hline
\end{tabular}

Correlation results for non-parametric water quality data and invertebrate parameters are seen in Table 10. Most invertebrate parameters in A1 were significantly correlated with water quality parameters, with the exception of the suspension feeding 
functional group, due its small sample size $(n=5)$. Dissolved oxygen was positively correlated with species richness, diversity, density, benthic abundance, epibenthic abundance, and filter feeder abundance. Salinity was negatively correlated with species richness, density, benthic abundance, epibenthic abundance, filter feeder abundance, and deposit feeder abundance. Depth was positively correlated with density, epibenthic abundance, filter feeder abundance, and predatory feeder abundance.

Fewer invertebrate parameters were significantly correlated with water quality parameters in SF2. Unlike A1, dissolved oxygen was negatively correlated with density and benthic abundance. Also unlike A1, salinity was positively correlated with benthic abundance and epibenthic abundance.

Mean invertebrate species richness, diversity, density and benthic invertebrate abundance in both seasons for structures and no structures in SF2 (bird islands and no structures) and A1 (wood structures and no structures) are shown in Figures 14-17. Only significant difference seemed to be in A1 in summer for overall density and benthic abundance. Structures sites show trends that structure support greater numbers than nonstructure sites.

Species richness, density, and benthic abundance were subjected to a two-way analysis of covariance and diversity was subjected to a two-way analysis of variance for structure (bird islands, no structures and wood structures, no structures) and season (summer, fall). Epibenthic, deposit, filter, suspension, and predatory feeder functional group data were subjected to a one-way Kruskal-Wallis test for structure type (bird islands, no structures and wood structures, no structures) and season (summer, fall). 
Table 10. Correlation results of non-parametric water quality parameters on benthic invertebrate criteria. All $p$-values determined using Spearman Table (Appendix E). All $p$-values $<0.05$ considered significant.

\begin{tabular}{|c|c|c|}
\hline \multirow{2}{*}{$\begin{array}{l}\text { Dependent } \\
\text { Variable }\end{array}$} & \multicolumn{2}{|c|}{ Results } \\
\hline & SF2 & A1 \\
\hline Species Richness & $\begin{array}{l}\text { DO: } \rho(28)=-0.27, p=0.10 \\
\text { Salinity: } \rho(28)=0.19, p>0.25\end{array}$ & $\begin{array}{l}\text { DO: } \boldsymbol{\rho}(\mathbf{3 1})=\mathbf{0 . 3 1}, \boldsymbol{p}=\mathbf{0 . 0 5} \\
\text { Salinity: } \boldsymbol{\rho}(\mathbf{3 1})=\mathbf{- 0 . 3 5}, \boldsymbol{p}=\mathbf{0 . 0 5} \\
\text { Depth: } \rho(31)=0.11, p>0.25\end{array}$ \\
\hline Diversity & $\begin{array}{l}\text { DO: } \rho(28)=0.12, p>0.25 \\
\text { Salinity: } \rho(28)=-0.26, p=0.10\end{array}$ & $\begin{array}{l}\text { DO: } \boldsymbol{\rho}(\mathbf{3 1})=\mathbf{0 . 3 4}, \boldsymbol{p}=\mathbf{0 . 0 5} \\
\text { Salinity: } \rho(31)=-0.10, p>0.25 \\
\text { Depth: } \rho(31)=0.20, p=0.25\end{array}$ \\
\hline Density & $\begin{array}{l}\text { DO: } \boldsymbol{\rho}(\mathbf{2 8})=\mathbf{- 0 . 4 6}, \boldsymbol{p}=\mathbf{0 . 0 1} \\
\text { Salinity: } \rho(28)=0.29, p=0.10\end{array}$ & $\begin{array}{l}\text { DO: } \rho(31)=0.43, p=0.01 \\
\text { Salinity: } \rho(31)=-0.57, p<0.01 \\
\text { Depth: } \rho(31)=0.31, p=0.05\end{array}$ \\
\hline Log Benthic & $\begin{array}{l}\text { DO: } \rho(28)=-0.56, p<0.01 \\
\text { Salinity: } \rho(28)=0.44, p=0.01\end{array}$ & 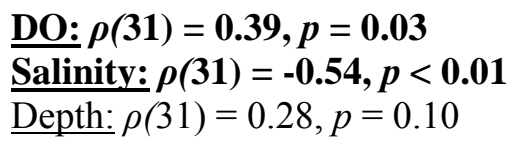 \\
\hline Log Epibenthic & $\begin{array}{l}\text { DO: } \rho(28)=-0.02, p>0.25 \\
\text { Salinity: } \boldsymbol{\rho}(\mathbf{2 8})=\mathbf{0 . 3 2}, \boldsymbol{p}=\mathbf{0 . 0 5} \\
\text { Temp: } \rho(28)=-0.15, p=0.25 \\
\text { Depth: } \rho(28),-0.03, p>0.25\end{array}$ & 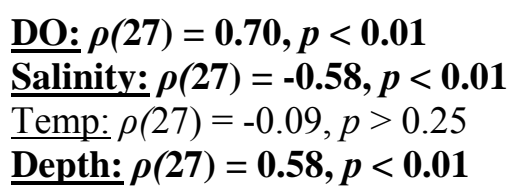 \\
\hline Log Deposit & $\begin{array}{l}\text { DO: } \rho(28)=-0.15, p=0.25 \\
\text { Salinity: } \rho(28)=0.17, p=0.25 \\
\text { Temp: } \rho(28)=-0.18, p=0.25 \\
\text { Depth: } \rho(28)=-0.12, p>0.25\end{array}$ & 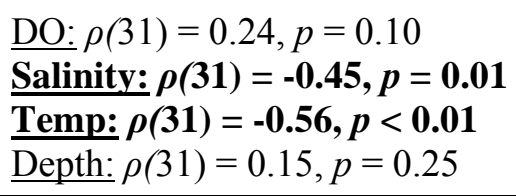 \\
\hline Log Filter & $\begin{array}{l}\text { DO: } \rho(17)=0.02, p>0.25 \\
\text { Salinity: } \rho(17)=-0.11, p>0.25 \\
\text { Temp: } \rho(17)=-0.01, p>0.25 \\
\text { Depth: } \rho(17)=0.16, p>0.25\end{array}$ & 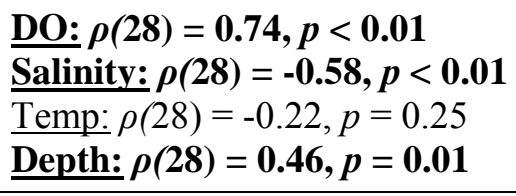 \\
\hline Log Suspension & 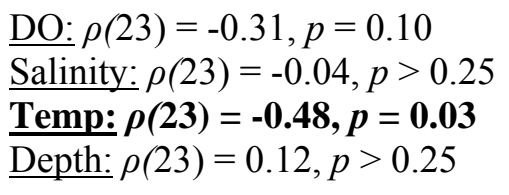 & $\begin{array}{l}\text { DO: } \rho(5)=-0.45, p>0.25 \\
\text { Salinity: } \rho(5)=0.89, p=0.10 \\
\text { Temp: } \rho(5)=0.22, p>0.25 \\
\text { Depth: } \rho(5)=0.23, p>0.25\end{array}$ \\
\hline Log Predatory & $\begin{array}{l}\text { DO: } \rho(27)=-0.44, p=0.03 \\
\text { Salinity: } \rho(27)=0.04, p>0.25 \\
\text { Temp: } \rho(27)=\mathbf{- 0 . 5 5 ,} \boldsymbol{p}<\mathbf{0 . 0 1} \\
\text { Depth: } \rho(27)=-0.03, p>0.25\end{array}$ & 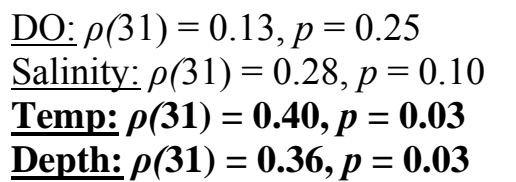 \\
\hline
\end{tabular}




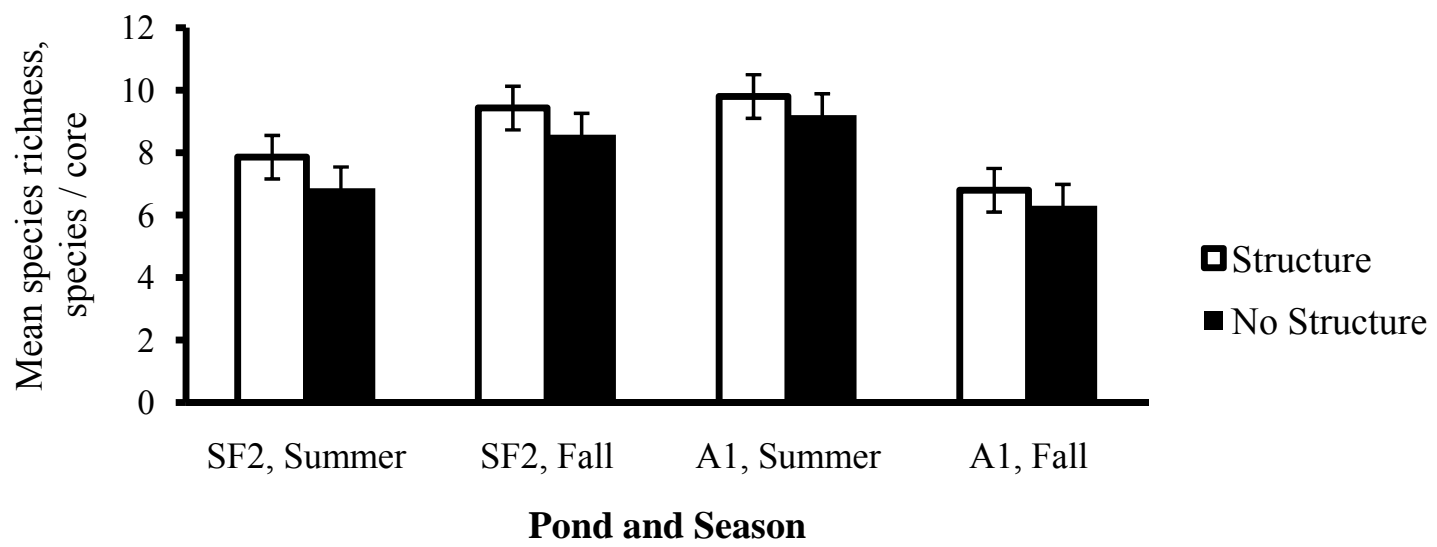

Figure 14. Mean $( \pm \mathrm{SE})$ invertebrate species richness for SF2 and A1 (summer and fall) for structure and no structure.

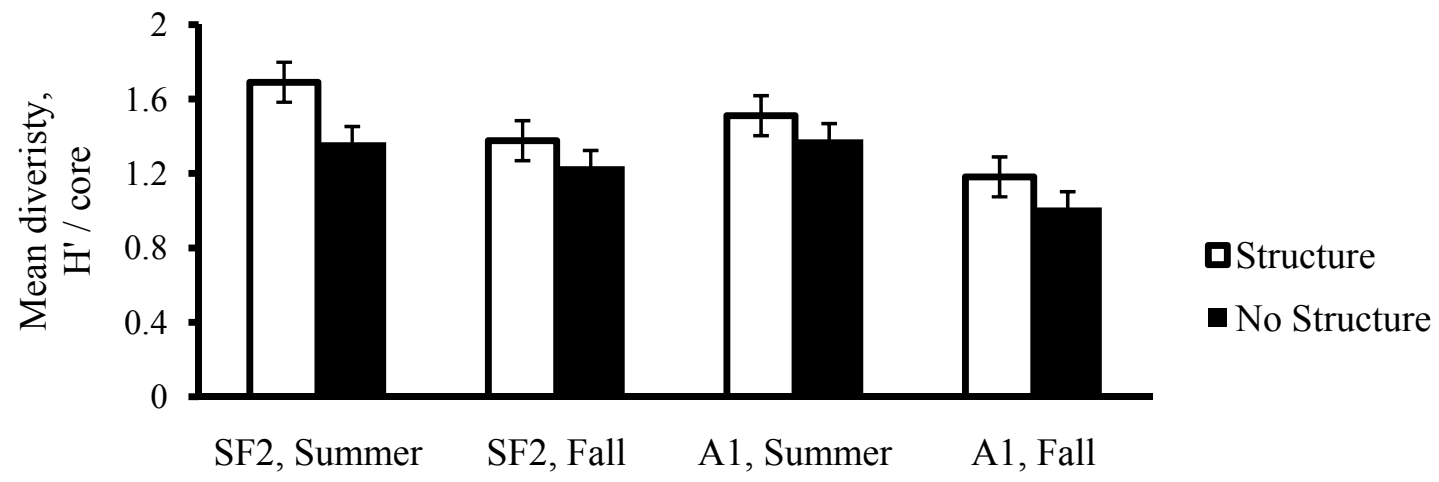

Pond and Season

Figure 15. Mean $( \pm \mathrm{SE})$ invertebrate diversity for SF2 and A1 (summer and fall) for structure and no structure.

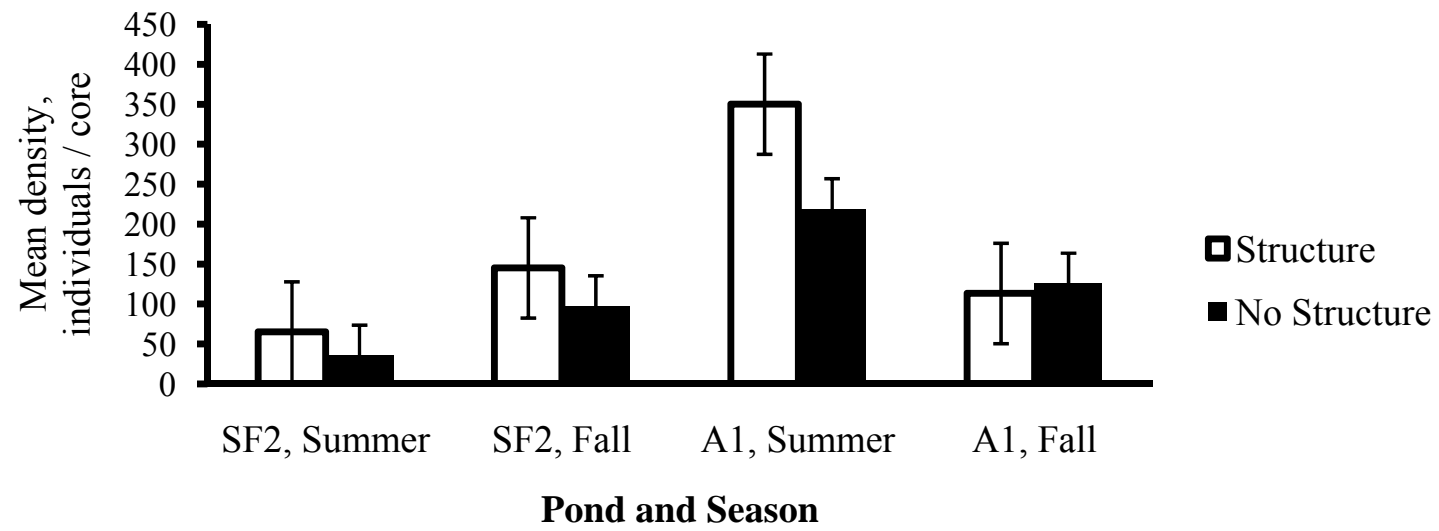

Figure 16. Mean $( \pm \mathrm{SE})$ invertebrate density for SF2 and A1 (summer and fall) for structures and no structures. 


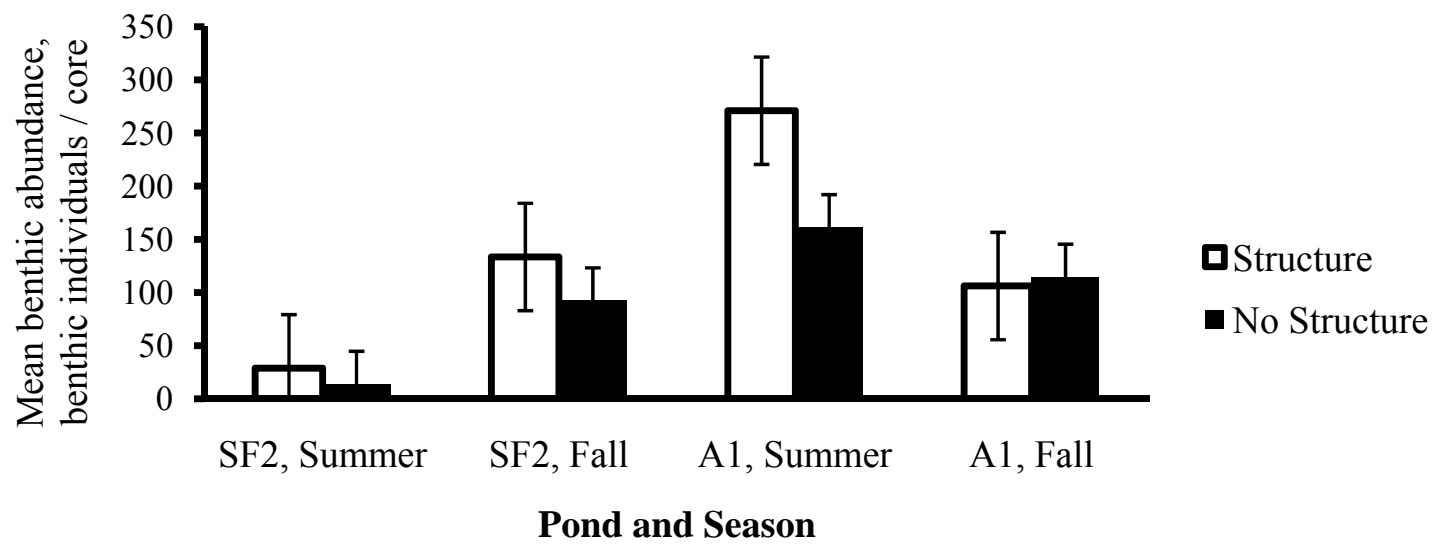

Figure 17. Mean ( \pm SE) benthic invertebrate abundance for SF2 and A1 (summer and fall) for structure and no structure.

There was no significant interaction between season and structures for any test. Results from the two-way ANCOVA, two-way ANOVA and Kruskal-Wallis tests can be seen in Tables 11 and 12. There was no significant structure effect in either SF2 or A1. The season effect was significant for diversity, density, and benthic abundance, as well as epibenthic abundance, deposit feeder abundance, and filter feeder abundance in A1. In SF2, results were significant for benthic abundance and predatory abundance. Temperature was a significant covariate in A1 for species richness, density, and benthic abundance and a significant covariate in SF2 for density and benthic abundance. 
Table 11. Two-way ANCOVA/ANOVA for season and structure effects on benthic invertebrate parameters. All $p$-values $<0.05$ considered significant.

\begin{tabular}{|c|c|c|}
\hline \multirow{2}{*}{$\begin{array}{c}\text { Dependent } \\
\text { Variable }\end{array}$} & \multicolumn{2}{|c|}{ Results } \\
\hline & SF2 & A1 \\
\hline $\begin{array}{l}\text { Species } \\
\text { Richness }\end{array}$ & $\begin{array}{l}\text { Season: } F(1,23)=1.49, p=0.24 \\
\text { Structure: } F(1,23)=1.03, p=0.32 \\
\text { Season*Structure: } F(1,23)=0.001, p=0.98 \\
\text { Temp: } F(1,23)=0.06, p=0.81\end{array}$ & 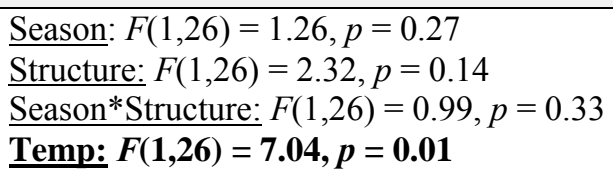 \\
\hline Diversity & $\begin{array}{l}\text { Season: } F(1,24)=2.20, p=0.15 \\
\text { Structure: } F(1,24)=2.37, p=0.14 \\
\text { Season*Structure: } F(1,24)=0.39, p=0.54\end{array}$ & $\begin{array}{l}\text { Season: } \boldsymbol{F ( 1 , 3 6 ) = 7 . 5 3 , p = 0 . 0 1} \\
\text { Structure: } F(1,36)=1.33, p=0.26 \\
\text { Season*Structure: } F(1,36)=0.02, p=0.88\end{array}$ \\
\hline Density & 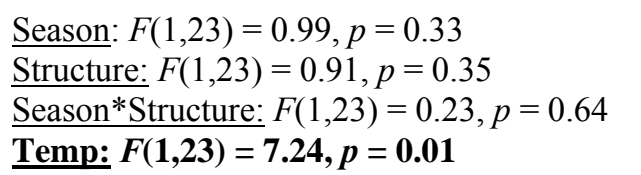 & 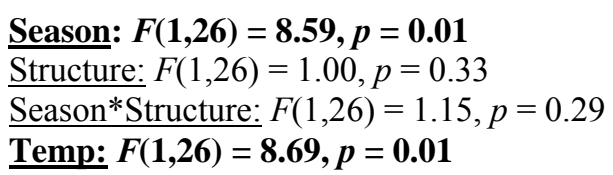 \\
\hline $\begin{array}{l}\text { Log } \\
\text { Benthic }\end{array}$ & 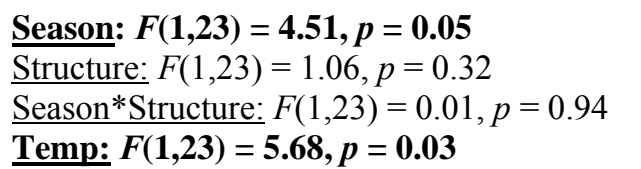 & 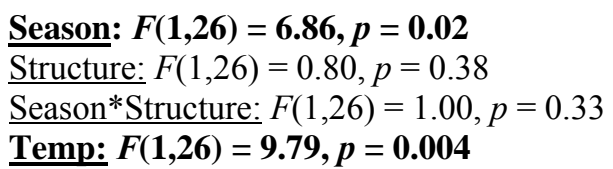 \\
\hline
\end{tabular}

Table 12. Kruskal-Wallis for season and structure effects on benthic invertebrate parameters. All $p$-values $<0.05$ considered significant.

\begin{tabular}{|c|c|c|}
\hline \multirow{2}{*}{$\begin{array}{l}\text { Dependent } \\
\text { Variable }\end{array}$} & \multicolumn{2}{|c|}{ Results } \\
\hline & SF2 & A1 \\
\hline $\begin{array}{l}\text { Log } \\
\text { Epibenthic }\end{array}$ & 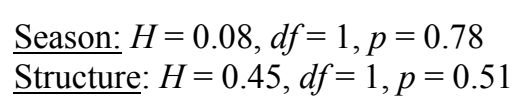 & $\begin{array}{l}\text { Season: } \boldsymbol{H}=\mathbf{1 5 . 3 7}, \boldsymbol{d f}=\mathbf{1}, \boldsymbol{p}<\mathbf{0 . 0 0 1} \\
\text { Structure: } H=0.33, d f=1, p=0.57\end{array}$ \\
\hline Log Deposit & $\begin{array}{l}\text { Season: } H=0.89, d f=1, p=0.35 \\
\text { Structure: } H=0.36, d f=1, p=0.55\end{array}$ & $\begin{array}{l}\text { Season: } \boldsymbol{H}=\mathbf{4 . 1 2}, \boldsymbol{d f}=\mathbf{1}, \boldsymbol{p}=\mathbf{0 . 0 4} \\
\text { Structure: } H=0.42, d f=1, p=0.52\end{array}$ \\
\hline Log Filter & $\begin{array}{l}\text { Season: } H=0.02, d f=1, p=0.88 \\
\text { Structure: } H=0.36, d f=1, p=0.55\end{array}$ & $\begin{array}{l}\text { Season: } \boldsymbol{H}=\mathbf{4 . 4 8}, \boldsymbol{d f}=\mathbf{1}, \boldsymbol{p}=\mathbf{0 . 0 3} \\
\text { Structure: } H=1.87, d f=1, p=0.17\end{array}$ \\
\hline $\begin{array}{c}\text { Log } \\
\text { Suspension }\end{array}$ & $\begin{array}{l}\text { Season: } H=2.45, d f=1, p=0.12 \\
\text { Structure: } H=0.35, d f=1, p=0.56\end{array}$ & $\begin{array}{l}\text { Season: } H=3.00, d f=1, p=0.08 \\
\text { Structure: } H=1.20, d f=1, p=0.27\end{array}$ \\
\hline $\begin{array}{l}\text { Log } \\
\text { Predatory }\end{array}$ & $\begin{array}{l}\text { Season: } \boldsymbol{H}=\mathbf{4 . 1 7}, \boldsymbol{d f}=\mathbf{1}, \boldsymbol{p}=\mathbf{0 . 0 4} \\
\text { Structure: } H=0.66, d f=1, p=0.42\end{array}$ & $\begin{array}{l}\text { Season: } H=0.32, d f=1, p=0.57 \\
\text { Structure: } H=0.42, d f=1, p=0.52\end{array}$ \\
\hline
\end{tabular}




\section{Discussion}

The main focus of this study was to determine if habitat quality of managed salt ponds could be improved based on the presence of habitat structures and their potential influence on benthic invertebrate abundance, diversity or density. Two types of structures were studied, bird islands in SF2 and wood structures in A1. The bird islands were composed of dirt, rocks, and contained some vegetation. The wood structures were former duck blinds and included wood stilts supporting a wooden enclosure, with some camouflage netting. I found that structures, regardless of the composition, were not statistically significant in affecting benthic invertebrate parameters. However, the raw benthic data averages suggest that structures may provide some influence on species richness, diversity, density, and functional group abundance.

In SF2, structure sites contained an additional species over control sites for both summer and fall. In addition, the density of invertebrates for summer bird island sites was 145.4 individuals per core compared to 97.6 individuals per core for control sites. In fall, the density for both structure and control sites did decrease, but bird island sites had 65.1 individuals per core while control sites only had 35.4 individuals per core.

In A1, average species richness and diversity were very similar for structure sites and control sites for both summer and fall. However, average density for summer showed 350.4 individuals per core for wood structure sites and only 218.9 individuals per core for control sites. Average densities for A1 for fall changed, with control sites having 126.6 individuals per core and wood structure sites having 115 individuals per core. This decline from summer to fall at structure and control sites appears to occur mainly in the 
deposit and filter feeding functional groups, suggesting that changes may be occurring at these wood structures, negatively affecting these functional groups.

Studies have shown that complex habitats often have greater abundances and diversities than simpler habitats from decreased physical stress, increased food availability, increased resource or niche availability, increased surface area, decreased competition, and increased refuges from predation (Bartholomew, Diaz, \& Cicchetti, 2000; Dean \& Connell, 1987; Diehl, 1988; Gorham \& Alevizon, 1989; Heck \& Wetstone, 1977; Hicks, 1985; O'Connor, 1991; Orth, Heck, \& Van Montfrans, 1984). Most studies have focused on the predator/prey relationship in complex habitats, including studying marine environments and invertebrate species (Aronson, 1986; Jordan, DeLeon, \& McCreary, 1996). Other studies have focused on aspects of a habitat for particular species, such as the analyzing the density of cordgrass blades as a source of structural complexity (Bell, 1985; Graham et al., 1998; James \& Heck, 1994; Schulman, 1996; van Dolah, 1978). Vegetation habitat complexity in freshwater pond environments was found to increase predation refuge for invertebrates (Anderson, 1984; Cryer \& Townsend, 1988; Heck \& Thoman, 1981; Lima \& Dill, 1990; Minello \& Zimmerman, 1983). However, few studies have been conducted to examine whether additional habitat structures, including non-vegetation structures, in marine pond habitats will affect benthic invertebrate assemblages. One study that did analyze structural complexity in a marine pond environment found that when structural complexity was low within a pond environment, benthic invertebrates were most affected by seasonal changes in the region (Shimabukuro \& Henry, 2011). 
Water quality parameters were tested during this study to determine any additional factors, beyond the presence of structure, which may have affected invertebrate parameters. I found that temperature was negatively correlated with species richness, density, and benthic and deposit feeder abundance in A1 and density and benthic, suspension feeder, and predatory feeder abundance in SF2. Temperature was also significantly correlated with dissolved oxygen and salinity reaffirming the wellknown relationship between temperature, dissolved oxygen, and salinity in marine pond environments (Leland \& Fend, 1998; McRae et al., 1998; Takekawa et al., 2001). However, due to non-normal data, regression analysis could not be conducted to reaffirm the directional relationship between these factors as studied in Lonzarich (1989), San Francisco Bay Conservation and Development Commission (2005), Courtney and Clements (1998), Liang et al. (2002) and Takekawa et al. (2006). These results support the idea that temperature, which also affects dissolved oxygen and salinity, can be a significant factor affecting benthic invertebrate populations. More research is needed in these pond environments to determine significant regression trends for temperature. This research is important because extreme temperature changes can result in metabolic changes, including elevated metabolism or restrictions to digestion (Helmuth \& Hofmann, 2001; Hofmann \& Somero, 1995, 1996), which also may occur more predominantly throughout various seasons.

The sampling for this study was conducted during two seasons: summer and fall. Summer sampling occurred in June and July, after migratory shorebirds and ducks have been overwintering for months but had migrated north. Fall monitoring occurred in 
September, prior to migratory shorebird and duck arrival back to the ponds. During sampling, I observed only resident bird species (black-necked stilt, American avocet, gulls, cormorants, white and brown pelicans) at SF2 and A1, suggesting that invertebrate sampling did occur between migratory bird departure and arrival. Sampling intended to capture the impact of migratory bird foraging on invertebrates and invertebrate response to the disturbance.

I found significant evidence that invertebrate parameters differed between seasons. The results suggest that the two ponds are being affected by different factors in each season. Benthic species fluctuate seasonally and over longer periods of time, and individual species can vary from year to year (Nichols, 1985a; Nichols \& Pamatmat, 1988). Natural variation in benthic populations is expected to occur due to seasonal changes in pond ecosystems, including recruitment and dormancy events for benthic invertebrates. Season was a significant factor for invertebrate densities and epibenthic abundance, most especially in A1. Density and epibenthic abundance was higher in A1 during the summer sampling, and decreased during fall. While epibenthic abundance in SF2 followed the same pattern, density for SF2 was higher in fall than in summer.

Benthic abundance for SF2 also increased from summer to fall, while benthic abundance decreased from summer to fall in A1, suggesting that different factors were affecting benthic populations in the ponds.

These differences may stem from the natural and structural differences between the ponds. SF2 has been restored to a managed pond habitat that is highly influenced by tidal changes and provides daily flushing of the pond. The inlet structures of the pond 
allow a regulated flow of Bay water through the system before it is discharged through the outlet structure during low tides (Levey et al., 2010). Channels are present around the bird islands and allow for strong currents to move water throughout the pond. Foraging areas are maintained at a low depth (around $10 \mathrm{~cm}$ ) to allow for probing birds to feed. These management strategies reduce the likelihood for stagnant water, limiting the influence of seasonal water quality extremes, while allowing for seasonal feeding by migratory birds.

Common shorebird food sources include bivalves, $N$. hinumensis, and Corophiidae amphipods, which are common near the Dumbarton Bridge (Thompson, 2010). Bivalve species typically decrease in density until fall when their numbers increase again, while Corophiidae and $N$. hinumensis decreased in abundance in spring before rebounding (Thompson, 2010). Bivalve distribution is also affected by seasonal fluctuations in the aquatic ecosystem. Bivalves almost completely disappear from shallow areas in winter and spring, possibly due to predation from shorebirds and bat rays, and decline slightly from deeper areas in winter (Thompson, 1999). In this study, I found that bivalve and Corophiidae abundance did slightly increase from summer to fall, while $N$. hinumensis abundance decreased from summer to fall. Overall, invertebrate parameters increased from summer to fall in SF2 supporting that foraging may affect abundances in summer, but the decline in predation and seasonal changes may affect the rate of invertebrate response in fall. However, other factors such as water quality or invertebrate life cycles, can strongly influence benthic invertebrate abundance and 
diversity. Further research is needed to examine how invertebrate species respond to these different factors.

A1 is a managed pond habitat with relatively low flow rates $(0.53 \mathrm{cu} . \mathrm{m} / \mathrm{s})$ throughout the pond and an average depth around $0.5 \mathrm{~m}$ (South Bay Salt Pond Initial Stewardship Plan, 2003). The inlet structure allows water to enter from Bay by gravity, but was not structured to regulate water depth or allow daily flushing of the system. Pond depths were typically twice as deep as those seen in SF2, potentially restricting the foraging of migratory birds because many shorebirds do not forage in depths greater than 10 to $15 \mathrm{~cm}$ (Isola, Colwell, Taft, \& Safran, 2000) or greater than $2 \mathrm{~m}$ for diving birds (Warnock et al., 2002). The higher invertebrate densities and abundances in summer may occur due to this restriction in avian predation and invertebrate recruitment.

The decline in invertebrate abundance and density in A1 from summer to fall may be explained by impacts of water quality changes. Bay water experiences the greatest temperature extremes in August (USGS, 2007), and temperature could be further increased in a slow-moving, non-flushing pond environment where temperatures could compound. However, mean temperature only slightly increased from summer to fall sampling. Salinity showed increases from summer to fall because of a decline in freshwater additions to the Bay and increased evaporation of the Bay water, leaving higher salt content (USGS, 2007). Invertebrate populations fluctuate in response to water fluctuations, most notably salinity (Leland \& Fend, 1998, McRae et al., 1998). Invertebrates must either be able to withstand these seasonal changes or be able to move to regions of preferred salinity (H.T. Harvey \& Associates, 2005). In addition, a 
significant decline in benthic dissolved oxygen, with black mud and hydrogen sulfide odors, indicated hypoxic conditions in the benthic zone in the fall. Hypoxic conditions (< $2 \mathrm{mg} / \mathrm{L}$ of dissolved oxygen) can lead to diminished populations and depleted trophic groups (Dauer \& Conner, 1980). The abundance of Capitellidae, Oligochaeta, and Spionidae annelids, and the limited presence of bivalves, amphipods and cumaceans in the fall also suggest a decline in benthic water quality. Capitellid polychaetes and oligochaete annelids are found in organically-enriched soils, and can also withstand low oxygen and other poor water quality and substrate conditions (Carlton, 2007). Lastly, spionid polychaetes are opportunistic worms, quickly colonizing recently disturbed environments (Carlton, 2007).

These seasonal changes can also be observed in the cumacean, $N$. hinumensis, which begins its recruitment event in approximately April, resulting in a large population of brooding females (Akiyama \& Yamamoto, 2004). The juveniles, after transitioning to the second juvenile stage, enter a summer diapause when seawater temperatures are approximately $28^{\circ} \mathrm{C}$, while a majority of cumacean adults die-off from temperature extremes (Akiyama \& Yamamoto, 2004). This early summer recruitment event may account for the large $N$. hinumensis populations during the summer sampling, and the summer diapause may account for the severe decline in populations during the fall sampling. Therefore, the invertebrate findings support the contention that changes in A1 are from pond conditions, rather than migratory bird foraging, but more research is needed to rule out other factors such as invertebrate life cycles or predation by other animals, such as the fish seen within the pond in the fall. 
Based on the common benthic invertebrates found by Carpelan (1957), Anderson (1970), Lonzarich (1989), Takekawa et al. (2004), Thompson (2010), and Brand et al. (2011) in low-salinity South Bay salt ponds, many of these invertebrate species or similar families were identified from SF2 and A1 salt ponds. Of those mentioned in the previous studies, Gemma gemma, Corbula amurensis, Spionidae (Polydora sp.), Nereis sp. (Nereis succinea), Capitellidae (Heteromastus sp.), Oligochaeta (Tubificoides sp.), Eogammarus confervicolus, Ampelisca abdita, Corophiidae and Podocopa (Ostracoda sp.) were found commonly at both sites.

Invertebrate species found in the ponds may indicate the habitat quality, current trends of the pond ecosystems, and provide important information for resource managers. Abundant species in SF2 in summer were N. hinumensis, Corophiidae amphipods, and Nereis procera polychaetes. In comparison, most abundant taxa in A1 during summer were G. gemma, N. hinumensis, and Oligochaeta. During the fall, Capitellidae, Corophiidae, Spionidae, and Grandidierella japonica were the most abundant in SF2, while Capitellidae, Oligochaeta, and Spionidae were the most abundant in A1.

One main invertebrate group that was not found during the course of my study, but is a common salt pond invertebrate is Nematoda. The limited occurrence of Nematoda was most likely due to limited experience benthic sampling and sieving by the researcher and assistants. Most marine nematodes live within the top several centimeters of sediment (Carlton, 2007), so the coring method used in this study should have extracted any nematodes that may have been present. However, the common sieving method for nematode fixation and identification involves adding seawater, in a volume at 
least fifty times that of the sediment sample, and agitating the mixture until the sediment is in suspension (Carlton, 2007). Once suspended, the mixture is allowed to settle for half a minute before the supernatant is poured through a 50 micron diameter mesh screen (Carlton, 2007). While this method is most common, the method used in this study has resulted in the finding of nematodes, even with using a 500 micron diameter mesh screen. Therefore, either the lack of experience in collection or in sorting through detritus with a dissecting microscope may have contributed to the lack of results rather than a lack of nematodes within the pond environments.

Of the feeding groups, deposit feeders were the best represented in both ponds during both seasons. Suspension feeders were the next most common group, except during summer in A1 in which filter feeders were the second-most represented group. Predatory feeders were the group that was least represented in both ponds during both seasons. The majority of the invertebrates sampled resided in the benthos of the ponds and were described as fairly sedentary or immobile. Invasive taxa found in the ponds includes the bivalves G. gemma, Mya arenaria, Corbula amurensis, and Musculista senhousia, cumacean N. hinumensis, amphipods G. japonica and Ampithoe valida, gastropod Haminoea japonica, decopod Hemigrapsus oregonensis, and tunicate Mogula manhanttensis. These invasive species contribute biological contamination upon their introduction and can create a series of ecological changes (USGS, 1997). For example, the amphipod G. japonica is an introduced species from Japan that feeds on epiphytes, suspended particles, detritus, and preys on other amphipods, changing the ecosystem structure upon their arrival (Carlton, 2007). 
While a majority of the bivalves found in the ponds were invasive, bivalves, the cumacean N. hinumensis, and Corophiidae amphipods are common shorebird food and therefore key taxa for resource managers (Gerken, 2005; Thompson, 2010). Additional taxa that are important for resource managers are taxa that provide nutrient cycling and enrichment in aquatic ecosystems. These taxa (clams, mussels and crustaceans) help regulate algal production in a nutrient-rich environment (USGS, 1997). Lastly, benthic invertebrates provide water and sediment quality indications based on their fluctuating populations over time (Thompson et al., 2007), and can provide data for pollution accumulation. Bivalves, typically $M$. petalum, have been used to determine metals accumulation in the tissue (Cain et al., 2005).

\section{Recommendations}

Findings from this study show that many factors can affect benthic invertebrate populations in marine pond environments. Restorations proposed in the South Bay salt ponds should be carefully assessed in order to create successful habitats for a variety of wildlife.

- Restoration managers should add structures to increase structural complexity in managed ponds. While results may not be statistically significant, these structures are inexpensive and easy to install and would increase the complexity in homogenous ponds. In addition, the presence of additional structures would provide additional opportunities for restoration managers to research the influence of structural complexity on salt pond benthic invertebrates. 
- Target species must be considered when managing benthic invertebrates. The abundance and diversity of benthic invertebrates influences which migratory birds feed at which ponds. Therefore, ponds need to be managed for target species, such as the restoration efforts in SF2 targeted shorebirds through flow and water depth regulation.

- Benthic invertebrates also need to be managed to target certain predator species. Restorations cannot solely focus on the pond specifications required to allow foraging for the target species, but also how different pond specifications affect the benthic invertebrate food source.

- Temperature was shown to be a significant factor in benthic invertebrate abundance and diversity in both ponds, and would need to be controlled to manage benthic invertebrate populations.

- Restoration managers need to manage deep ponds, especially A1, for better water quality for healthier benthic populations. Benthic populations in A1 were extremely affected by seasonal water quality changes, including hypoxia in the benthos, which may have caused the large decline in benthic populations. By regulating the benthic water quality, populations may experience less frequent or extreme die-offs and result in more stable benthic populations.

- Future monitoring and research should continue at SF2 and A1, but extend to include more ponds and delve more extensively into additional factors affecting benthic populations. 
- Benthic invertebrate life histories need to be better understood to determine how recruitment naturally occurs in the South Bay. With this additional information, restoration managers will be able to better develop restoration goals, plan, and monitor existing managed ponds. 


\section{References}

Accurso, L. (1992). Distribution and abundance of wintering waterfowl on San Francisco Bay 1988-1990. Master's Thesis, Humboldt State University, Humboldt, California, United States.

Akiyama, T., \& Yamamoto, M. (2004). Life history of Nippoleucon hinumensis (Crustacea: Cumacea: Leuconidae) in Seto Island Sea of Japan: Summer diapauses and molt cycle. Marine Ecology Progress Series, 284, 211-225.

Alpine, A. E., \& Cloern, J. E. (1992). Trophic interactions and direct physical effects control phytoplankton biomass and production in an estuary. Limnology and Oceanography, 37, 946-955.

Anderson, J. T., \& Smith, L. M. (1999). Carrying capacity and diel use of managed playa wetlands by nonbreeding waterbirds. Wildlife Society Bulletin, 27, 281291.

Anderson, J. T., \& Smith, L. M. (2004). Persistence and colonization strategies of playa wetland invertebrates. Hydrobiologia, 513, 77-86.

Anderson, W. (1970). A preliminary study of the relationship of salt ponds and wildlife - south San Francisco bay. California Fish and Game, 56, 240-252.

Aronson, R. B. (1986). Life history and den ecology of Octopus briareus robson in a marine lake. Journal of Experimental Marine Biology and Ecology, 95, 37-54.

Atwater, B., Hedel, C., \& Helley, E. (1977). Late quaternary depositional history, Holocene sea-level changes, and vertical crustal movement, southern San Francisco Bay, California. Washington, D.C: U.S. Geological Survey.

August, P. (1983). The role of habitat complexity and heterogeneity in structuring tropical mammal communities. Ecology, 64(6), 1495-1507.

Bartholomew, A., Diaz, R., \& Cicchetti, G. (2000). New dimensionless indices of structural habitat complexity: predicted and actual effects on a predator's foraging success. Marine Ecology Progress Series, 26, 45-58.

Batzer, D. P., Cooper, R., \& Wissinger, S. A. (2006). Wetland animal ecology. In Batzer, D. P., \& Sharitz, R. R. (Eds.), Ecology of freshwater and estuarine wetlands (pp. 242-284). Berkeley: University of California Press.

Batzer, D. P., \& Sharitz, R. R. (Eds.). (2006). Ecology of freshwater and estuarine wetlands. Berkeley: University of California Press. 
Batzer, D. P., Rader, R. R., \& Wissinger, S. A. (Eds.). Invertebrates in freshwater wetlands of North America: Ecology and management. New Jersey: John Wiley $\&$ Sons, Inc.

Bell, S. S. (1985). Habitat complexity of polychaete tube caps: influence of architecture on dynamics of a meioepibenthic assemblage. Journal of Marine Research, 43, $647-657$.

Bilby, R. E., \& Bisson, P. A. (1998). Function and distribution of large woody debris. In Kantor, S., Naiman, R., \& Bilby, R. (Eds.), River ecology and management: Lessons from the Pacific coastal ecoregion (pp. 324-436). New York: SpringerVerlag.

Brand, L. A., Woo, I., Smith, A., Smith, L., Moskal, S., \& Takekawa, J. Y. (2011). Effects of regional wetland restoration on the Alviso shoals of South San Francisco Bay: Pre-restoration assessment of shorebird and invertebrate populations. Data Summary Report. Vallejo, CA: U. S. Geological Survey, Western Ecological Research Center.

Brew, D. S., \& Williams, P. B. (2010). Predicting the impact of large-scale tidal wetland restoration on morphodynamics and habitat evolution in south San Francisco bay, California. Journal of Coastal Research, 26(5), 912-924.

Brooks, R. T. (2000). Annual and seasonal variation and the effects of hydroperiod on benthic macroinvertebrates of seasonal forest ('vernal') ponds in central Massachusetts, USA. Wetlands, 20,707-715.

Cain, D. J., Parchaso, F., Thompson, J., Luoma, S., Lorenzi, A., Moon, E., ... Dyke, J. (2005). Near-field receiving water monitoring of trace metals and a benthic community near the Palo Alto Regional Water Quality Control Plant in south San Francisco Bay, California: 2005. 2006-1152 U.S. Geological Survey.

Carlton, J. T. (1975). Introduced intertidal invertebrates. In Smith, R. I., \& Carlton, J. (Eds.), Light's manual: Intertidal invertebrates of the central California coast (pp. 17-25). Berkeley: University of California Press.

Carlton, J. T. (1979). Introduced invertebrates of San Francisco Bay. In: Cosmos, T. J. (Ed.), San Francisco Bay: The urbanized estuary (pp. 427-444). San Francisco: Pacific Division, American Association for the Advancement of Science.

Carlton, J. T. (Ed.). (2007). The Light and Smith manual: Intertidal invertebrates from central California to Oregon. Berkeley and Los Angeles: University of California Press. 
Carlton, J. T., Thompson, J. K., Schemel, L. E., \& Nichols, F. H. (1990). Remarkable invasion of San Francisco Bay, California, USA by the Asian clam Potamocorbula amurensis: Introduction and dispersal. Marine Ecology Progress Series, 66(1-2), 81-95.

Carpelan, L. H. (1957). Hydrobiology of the Alviso salt ponds. Ecology, 38(3), 375390.

City of San José. “About San José.” Retrieved February 22, 2010 from http://www.sanJoséca.gov/about.asp.

Cohen, A. N., \& Carlton, J. T. (2003). Nonindigenous aquatic species in a United States estuary: A case study of the biological invasions of the San Francisco Bay and Delta. NA36RG0467 U.S. Fish and Wildlife Service and the National Sea Grant College Program.

Coleman, B. D. (1981). On random placement and species-area relations. Mathematical Biosciences, 54, 191-215.

Colwell, M. A., \& Jehl, J. R. (1994). Wilson's phalarope (Phalaropus tricolor). In: Poole, A., \& Gill, F. (Eds.), The birds of North America, no. 83. Washington, DC: Academy of Natural Sciences, Philadelphia, and American Ornithologists' Union.

Colwell, M. A., \& Landrum, S. L. (1993). Nonrandom shorebird distribution and finescale variation in prey abundance. Condor, 95, 94-103.

Connell, J. H. (1978). Diversity in tropical rain forests and coral reefs. Science, 199, 1302-1310.

Connor, E. F., \& McCoy, E. D. (1979). Statistics and biology of the species-area relationship. American Naturalist, 113, 791-833.

Cosmos, T. J. (Ed.). (1979). San Francisco Bay: The urbanized estuary. San Francisco: Pacific Division, American Association for the Advancement of Science.

Courtney, L. A., \& Clements, W. H. (1998). Effects of acidic pH on benthic macroinvertebrate communities in microcosms. Hydrobiologia, 379, 135-145.

Cox, M. C. (1969). The biology of the euryhaline water boatman Trichocorixa reticulata (Guerin-Meneville). Unpublished Master's thesis: San Diego State University, San Diego, California, United States.

Cressey, S. (1997). Benthos and fisheries assessment Palo Alto wastewater treatment plant discharge channel. California: Larry Walker Associates. 
Cryer, M., \& Townsend, C. R. (1988). Spatial distribution of zooplankton in a shallow eutrophic lake, with a discussion of its relation to fish predation. Journal of Plankton Research, 10, 487-501.

Cummins, K. W. (1973). Trophic relations of aquatic insects. Annual Review of Entomology, 18, 183-206.

Dauer, D. M., \& Conner, W. G. (1980). Effects of moderate sewage input on benthic polychaete populations. Estuarine and Coastal Marine Science, 10, 335-346.

Davis, C. A., \& Bidwell, J. R. (2008). Response of aquatic invertebrates to vegetation management and agriculture. Wetlands, 28, 793-805.

De Groot, D. (1927). The California clapper rail: Its nesting habits, enemies and habitat. Condor, 29, 259-270.

De Szalay, F. A., \& Resh, V. H. (1996). Spatial and temporal variability of trophic relationships among aquatic macroinverterates in a seasonal marsh. Wetlands, 16, $458-466$.

Dean, R. L., \& Connell, J. H. (1987). Marine invertebrates in an algal succession: Mechanisms linking habitat complexity with diversity. Journal of Experimental Marine Biology and Ecology, 109, 249-273.

Dedrick, K. (1989). Proceedings from Coastal Zone '89: Sixth symposium on coastal and ocean management. New York: American Society of Civil Engineers.

Diehl, S. (1988). Foraging efficiency of three freshwater fishes: effects of structural complexity and light. Oikos, 53, 207-214.

Dodson, S. (2001). Zooplankton communities of restored depressional wetlands in Wisconsin, USA. Wetlands, 21, 292-300.

Downes, B. J., Lake, P. S., Schreiber, E. S. G., \& Glaister, A. (1998). Habitat structure and regulation of local species diversity in a stony, upland stream. Ecological Monographs, 68, 237-258.

Emergency Wetlands Resources Act of 1986 § 16 U.S.C. $§ 3901-3932$.

Field, M. A. (1914). Chimes of mission bells: A historical sketch of California and her missions. San Francisco: Philopolis Press. 
Fowler, B. H. (1977). Biology and life history of the salt marsh snail, Assiminea californica. Unpublished Master's thesis: San José State University, San José, California, United States.

Fulfrost, B. (2010). Annual report (year one) on the habitat evolution mapping project for the South Bay Salt Pond Restoration Project. Annual Report. California: South Bay Salt Pond Restoration Project.

Furse, M., Hering, D., Moog, O., Verdonschot, P., Johnson, R., Brabec, K., ... Krno, I. (2006). The STAR project: context, objectives and approaches. Hydrobiologia, $566,3-29$.

Gerken, S. (2005). Life history of the cumacea. Retrieved from "Cumaceans of the World," http://afsag.uaa.alaska.edu.

Gill, R. (1979). Status and distribution of the California clapper rail (Rallus longirostris obsoletus). California Fish and Game, 65, 36-49.

Goman, M., Malamud-Roam, F., \& Ingram, B. (2008). Holocene environmental history and evolution of a tidal salt marsh in San Francisco Bay, California. Journal of Coastal Research, 24(5), 1126-1137.

Gorham, J. C., \& Alevizon, W. S. (1989). Habitat complexity and the abundance of juvenile fishes residing on small scale artificial reefs. Bulletin of Marine Science, $44,662-665$.

Graham, S., Davis, J., Deegan, L., Cebrian, J., Hughes, J., \& Hauxwell, J. (1998). Effect of eelgrass (Zostera marina) density on the feeding efficiency of mummichog (Fundulus heteroclitus). Biological Bulletin, 195, 241-243.

Greenberg, R., Maldonado, J., Droege, S., \& McDonald, M. (2006). Tidal marshes: A global perspective on the evolution and conservation of their terrestrial vertebrates. BioScience, 56(8), 675-685.

Grime, J. P. (1977). Evidence for the existence of three primary strategies in plants and its relevance to ecological and evolutionary theory. American Naturalist, 111, 1169-1194.

H. T. Harvey \& Associates. (2005). Biology and habitats: Existing conditions report. Technical Documents. California: South Bay Salt Pond Restoration Project.

Hamilton, R. B. (1975). Comparative behavior of the American avocet and the Blacknecked stilt (Recurvirostridae). Berkeley: University of California Press. 
Hanna, G. D. (1966). Introduced mollusks of western North America. California Academy of Science, 48, 108.

Harmon, M., Franklin, J., Swanson, F., Sollins, P., Gregory, S., Lattin, J., ...Cummins, K. (1986). Ecology of coarse woody debris in temperate ecosystems. Advances in Ecological Research, 15, 133-302.

Harvey, H. T., Haltiner, J., \& Williams, P. (1982). Guidelines for enhancement and restoration of diked historic baylands. U.S.: San Francisco Bay Conservation and Development Commission.

Harvey, T. (1988). Breeding biology of the California clapper rail in south San Francisco Bay. Transactions of the Western Section of the Wildlife Society, 24, 98-104.

Harvey, T. E, Hothem, R. L., Keck, R. A., Miller, K. J., Page, G. W., \& Rauzon, M. J. (1992). Status and trends report on wildlife of the San Francisco Estuary. U.S.: U.S. Fish and Wildlife Service.

Heck, K. L., \& Thoman, T. A. (1981). Experiments on predator-prey interactions in vegetated aquatic habitats. Journal of Experimental Marine Biology and Ecology, $53,125-134$.

Heck, K. L., \& Wetstone, G. S. (1977). Habitat complexity and invertebrate species richness and abundance in tropical seagrass meadows. Journal of Biogeography, 4, 135-142.

Helmuth, B. S. T., \& Hofmann, G. E. (2001). Microhabitats, thermal heterogeneity, and patterns of physiological stress in the rocky intertidal zone. Biological Bulletin, 201, 374-384.

Hickey, C., Warnock, N., Takekawa, J., \& Athearn, N. (2007). Space use by blacknecked stilts Himantopus mexicanus in the San Francisco bay estuary. Ardea, 95, 275-288.

Hicks, G. R. F. (1985). Meiofauna associated with rocky shore algae. In: Moore, P. G., \& Seed, R. (Eds.), The ecology of rocky coasts (pp. 36-64). London: Hoder \& Stoughton.

Hofmann, G. E., \& Somero, G. N. (1995). Evidence for protein damage at environmental temperatures: seasonal changes in levels of ubiquitin conjugates and hsp70 in the intertidal mussel Mytilus trossulus. Journal of Experimental Biology, 198, 1509-1518. 
Hofmann, G. E., \& Somero, G. N. (1996). Interspecific variation in thermal denaturation of proteins in congeneric mussels Mytilus trossulus and $\mathrm{M}$. galloprovincialis: Evidence from the heatshock response and protein ubiquitination. Marine Biology, 126, 65-75.

Holloran, P. (1998). Seeing the trees through the forest: Oaks and history in the presidio. San Francisco: City Light Books.

Hughes, R. (2012). Disturbance and diversity: An ecological chicken and egg problem. Nature Education Knowledge, 3(10), 48.

Huston, M. A. (1979). A general hypothesis of species diversity. American Naturalist, $113,81-101$.

Huston, M. A. (1994). Biological diversity: The coexistence of species in changing landscapes. Cambridge: Cambridge University Press.

Huston, M. A. (1997). Hidden treatments in ecological experiments: re-evaluating the ecosystem function of biodiversity. Oecologia, 110, 449-460.

Isola, C. R., Colwell, M. A., Taft, O. W., \& Safran, R. J. (2000). Interspecific differences in habitat use of shorebirds and waterfowl foraging in managed wetlands of California's San Joaquin Valley. Waterbirds, 23, 196-203.

James, P. L., \& Heck, K. L. (1994). The effects of habitat complexity and light intensity on ambush predation within a simulated seagrass habitat. Journal of Experimental Marine Biology and Ecology, 176, 187-200.

Jang, E. B. (1977). Hydromineral regulation in the saline water corixid Trichocorixa reticulate. Unpublished Master's thesis, California State University, Hayward, Hayward, California, United States.

Jehl, J. R. (1988). Biology of the eared grebe and Wilson's phalarope in the nonbreeding season: A study of adaptations to saline lakes. Allen, Kansas: Allen Press, Inc.

Jordan, F., DeLeon, C. J., \& McCreary, A. C. (1996). Predation, habitat complexity, and distribution of the crayfish Procambarus alleni within a wetland mosaic.

Wetlands, 16, 452-457.

Josselyn, M. (1983). The ecology of San Francisco Bay tidal marshes: a community profile. Biological Report. United States: 0895-1926 National Coastal Ecosystems Teams, U.S. Fish and Wildlife Service. 
Kantor, S., Naiman, R., \& Bilby, R. (Eds.). (1998). River ecology and management: Lessons from the Pacific coastal ecoregion. New York: Springer-Verlag.

Kjelmyr, J., Page, G., Shuford, W., \& Stenzel, L. (1991). Shorebird numbers in wetlands of the Pacific flyway: A summary of spring, fall, \& winter counts in 1988, 1989, and 1990. Unpublished report. Bolinas, California: Point Reyes Bird Observatory.

Kon, K., Kurokura, H., \& Tongnunui, P. (2009). Do mangrove root structures function to shelter benthic macrofauna from predators? Journal of Experimental Marine Biology and Ecology, 370, 1-8.

Larsson, B. C. (2000). Franciscan brine shrimp. In Olofson, P. (Ed.), Baylands ecosystem species and community profiles: Life histories and environmental requirements of key plants, fish and wildlife (pp. 150-152). California: Goals Project, San Francisco Bay Regional Water Quality Control Board.

Leland, H. V., \& Fend, S. V. (1998). Benthic invertebrate distribution in the San Joaquin River, California, in relation to physical and chemical factors. Canadian Journal of Fisheries and Aquatic Science, 55, 1051-1067.

Levey, J. R., Vasicek, P., Fricke, H., Archer, J., \& Henry, R. F. (2010). Salt pond SF2 restoration, wildlife, and habitat protection. Washington: Art Anderson Associates.

Liang, S., Shieh, B., \& Fu, Y. (2002). A structural equation model for physiochemical variables of water, benthic invertebrates, and feeding activity of waterbirds in the Sitsao wetlands of southern Taiwan. Zoological Studies, 41(4), 441-451.

Lima, S. L., \& Dill, L. M. (1990). Behavioural decisions made under the risk of predation: a review and prospectus. Canadian Journal of Zoology, 68, 619-640.

Lloyd, M., \& Ghelardi, R. J. (1964). A table for calculating the 'equitability' component of species diversity. Journal of Animal Ecology, 33, 217-225.

Lonzarich, D. J., \& Smith, J. (1997). Water chemistry and community structure of saline and hypersaline salt evaporation ponds in San Francisco Bay, California. California Fish and Game, 83, 89-104.

Lonzarich, D. J. (1989). Temporal and spatial variations in salt pond environments and implications for fish and invertebrates. Master's Thesis, San José State University, San José, California, United States.

MacArthur, R. H., \& Wilson, E. O. (1967). The theory of island biogeography. New Jersey: Princeton University Press. 
Maffei, W. A. (2000a). Brine flies. In Olofson, P. (Ed.), Baylands ecosystem species and community profiles: Life histories and environmental requirements of key plants, fish and wildlife (pp. 179-182). California: Goals Project, San Francisco Bay Regional Water Quality Control Board.

Maffei, W. A. (2000b). A note on invertebrate populations of the San Francisco estuary. In Olofson, P. (Ed.), Baylands ecosystem species and community profiles: Life histories and environmental requirements of key plants, fish and wildlife (pp. 184192). California: Goals Project, San Francisco Bay Regional Water Quality Control Board.

Maser, C., Tarrant, R. F., Trappe, J. M., \& Franklin, J. F. (Eds.). (1988). From the forest to the sea: A story of fallen trees. General Technical Report PNW-GTR-229. Oregon: Pacific Northwest Research Station, U.S. Department of Agriculture.

Matias, M. G., Underwood, A. J., Hochuli, D. F., \& Coleman, R. A. (2010). Independent effects of patch size and structural complexity on diversity of benthic macroinvertebrates. Ecology, 91(7), 1908-1915.

McCoy, E. D., \& Bell, S. S. (1991). Habitat structure: the evolution and diversification of a complex topic. In McCoy, E. D., Bell, S. S., \& Mushinsky, H. R. (Eds.), Habitat structure: the physical arrangement of objects in space (pp. 3-27). London: Chapman and Hall.

McCoy, E. D., Bell, S. S., \& Mushinsky, H. R. (Eds.). (1991). Habitat structure: the physical arrangement of objects in space. London: Chapman and Hall.

McGinnis, S. M. (1984). Freshwater fishes of California. Berkeley: University of California Press.

McRae, G., Camp, D. K., Lyons, W. G., \& Dix, T. L. (1998). Relating benthic infaunal community structure to environmental variables in estuaries using nonmetric multidimensional scaling and similarity analysis. Environmental Monitoring and Assessment, 51, 233-246.

Meiorin, E. C., Josselyn, M. N., Crawford, R., Calloway, J., Miller, K., Pratt, R., ... Leidy, R. (1991). Status and trends report on wetlands and related habitats in the San Francisco estuary. Oakland, CA: San Francisco Estuary Project.

Mejia, F., Saiki, M. K., \& Takekawa, J. Y. (2008). Relation between species assemblages of fishes and water quality in salt ponds and sloughs in south San Francisco bay. The Southwestern Naturalist, 53(3), 335-345. 
Merritt, R. W., Cummins, K. W., \& Burton, T. M. (1983). The role of aquatic insects in the processing and cycling of nutrients. In Resh, V. H., \& Rosenberg, D. M. (Eds.), The Ecology of Aquatic Insects (pp. 134-163). New York: Praeger.

Minello, T. J., \& Zimmerman, R. J. (1983). Fish predation on juvenile brown shrimp, Penaeus aztecus Ives: The effect of simulated Spartina structure on predation rates. Journal of Experimental Marine Biology and Ecology, 72, 211-231.

Moore, P. G., \& Seed, R. (Eds.). (1985). The ecology of rocky coasts. London: Hoder \& Stoughton.

Moskal, S. (2013). If you build it, will they come? Response of waterbirds to salt pond enhancements in pond SF2. E-newsletter. California: South Bay Salt Pond Restoration Project.

Moyle, P. B. (1976). Fish introduction in California: history and impact on native fishes. Biological Conservation, 9, 101-118.

Nichols, F. H. (1979). Natural and anthropogenic influences on benthic community structure in San Francisco Bay. U.S.: U.S. Geological Survey, Pacific Division.

Nichols, F. H., \& Pamatmat, M. M. (1988). The ecology of soft-bottom benthos of San Francisco Bay, California USA, a community profile. U.S. Fish and Wildlife Service Biological Report, 85(719), 1-74.

Nichols, F. H., \& Thompson, J. K. (1985a). Persistence of an introduced mudflat community in South San Francisco Bay, California. Marine Ecology Progress Series, 24, 83-97.

Nichols, F. H., \& Thompson, J. K. (1985b). Time scales of change in the San Francisco Bay benthos. Hydrobiologia, 129, 121-138.

Niesen, T. M., \& Lyke, E. B. (1981). Pioneer infaunal communities in the Hayward salt marsh restoration (San Francisco Bay). Estuaries, 4(3), 243.

O'Connor, N. A. (1991). The effects of habitat complexity on the macroinvertebrates colonising wood substrates in a lowland stream. Oecologia, 85, 504-512

Olofson, P. R. (Ed.). (2000). Baylands ecosystem species and community profiles: Life histories and environmental requirements of key plants, fish and wildlife. California: Goals Project, San Francisco Bay Regional Water Quality Control Board. 
Orth, R. J., Heck, K. L., \& Van Montfrans, J. (1984). Faunal communities in seagrass beds: a review of the influence of plant structure and prey characteristics on predator-prey relationships. Estuaries, 7, 339-350.

Page, G., Stenzel, L., \& Wolfe, C. (1999). Aspects of the occurrence of shorebirds on a central California estuary. Studies in Avian Biology, 2, 15-32.

Painter, R. E. (1966). Zoobenthos of San Pablo and Suisun bays. Fisheries Bulletin 133. Sacramento, CA: California Department of Fish and Game.

Paulson, D. (1993). Shorebirds of the Pacific Northwest. Washington: University of Washington Press.

Peet, R. K. (1974). The measurement of species diversity. Annual Review of Ecology and Systematics, 5, 285-307.

Philip Williams \& Associates, \& Faber, P. (2004). Design guidelines for tidal wetland restoration in San Francisco Bay. Oakland, CA: The Bay Institute and California State Coastal Conservancy.

Poole, A., \& Gill, F. (Eds.). (1994). The birds of North America, no. 83. Washington, DC: Academy of Natural Sciences, Philadelphia, and American Ornithologists' Union.

Progress at the Alviso Ponds. (2013). U.S.: South Bay Salt Pond Restoration Project. Retrieved August 10, 2013 from http://southbayrestoration.org.

Progress at the Ravenswood Ponds. (2013). South Bay Salt Pond Restoration Project. Retrieved August 10, 2013 from http://southbayrestoration.org.

Rader, R. B. (2001). An introduction to wetland bioassessment and management. In Rader, R. B., Batzer, D. P., \& Wissinger, S. A. (Eds.), Bioassessment and management of North American freshwater wetlands (pp. 1-9). New Jersey: John Wiley \& Sons, Inc.

Rader, R. B., Batzer, D. P., \& Wissinger, S. A. (Eds.). (2001). Bioassessment and management of North American freshwater wetlands. New Jersey: John Wiley \& Sons, Inc.

Reeder, W. G. (1951). Stomach analysis of a group of shorebirds. Condor, 53, 43-45.

Resh, V. H., \& Rosenberg, D. M. (Eds.). (1983). The ecology of aquatic insects. New York: Praeger. 
Ricklefs, R. E., \& Lovette, I .J. (1999). The roles of island area per se and habitat diversity in the species-area relationships of four Lesser Antillean faunal groups. Journal of Animal Ecology, 68, 1142-1160.

Rintoul, C., Warnock, N., \& Page, G. W. (2003). Breeding status and habitat use of black-necked stilts and American avocets in south San Francisco Bay. Western Birds, 34, 2-14.

Rubega, M. A., \& Inouye, C. (1994). Switching in phalaropes: feeding limitations, the functional response and water policy at Mono Lake, CA. Biological Conservation, 70, 205-210.

Rundle, W. D. (1982). A case for esophageal analysis in shorebird food studies. Journal of Field Ornithology, 55, 249-257.

Safran, R. J., Isola, C. R., Colwell, M. A., \& Williams, O. E. (1997). Benthic invertebrates at feeding locations of nine waterbird species in managed wetlands of the northern San Joaquin Valley, California. Wetlands, 17, 407-415.

San Francisco Bay Conservation and Development Commission. (2005). Staff Report. San Francisco, CA: San Francisco Bay Conservation and Development Commission.

Schulman, J. (1996). Habitat complexity as a determinant of juvenile blue crab survival. VIMS dissertation, College of William and Mary, Gloucester Point, Virginia, United States.

Sedell, J. R., Bisson, P. A., Swanson, F. J., \& Gregory, S. V. (1988). What we know about large trees that fall into streams and rivers. In Maser, C., Tarrant, R. F., Trappe, J. M., \& Franklin, J. F. (Eds.), From the forest to the sea: A story of fallen trees. General Technical Report PNW-GTR-229 (pp. 47-79). Oregon: Pacific Northwest Research Station, U.S. Department of Agriculture.

Shannon, C. E., \& Weaver, W. (1949). The mathematical theory of communication. Urbana: University of Illinois Press.

Shimabukuro, E. M., \& Henry, R. (2011). Controlling factors of benthic macroinvertebrates distribution in a small tropical pond, lateral to the Paranapanema River (Sao Paulo, Brazil). Acta Limnologica Brasiliensia (Biological Limnology), 23(2), 154-163.

Simberloff, D. (1976). Experimental zoogeography of islands: effects of island size. Ecology, 57, 629-648. 
Skinner, J. E. (1962). An historical review of the fish and wildlife resources of the San Francisco Bay area. Report No. 1. California, U.S.: The Resources Agency of California Department of Fish and Game Water Projects Branch.

Smith, R. I., \& Carlton, J. (Eds.). (1975). Light's manual: Intertidal invertebrates of the central California coast. Berkeley: University of California Press.

South Bay Salt Pond Restoration Project. (2010). Official Website.

Sousa, W. P. (1979). Disturbance in marine intertidal boulder fields: the nonequilibrium maintenance of species diversity. Ecology, 60, 1225-1239.

Strange, C. (2008). Troubling waters. BioScience, 58(11), 1008-1013.

Takekawa, J. Y., Lu, C. T., \& Pratt, R. T. (2001). Avian communities in baylands and artificial salt evaporation ponds of the San Francisco bay estuary. Hydrobiologia, 466, 317-328.

Takekawa, J. Y., Miles, A. K., Schoellhamer, D. H., Athearn, N. D., Saiki, M. K., Duffy, W. D., ... Jannusch, C. A. (2004). Trophic structure and avian communities across a salinity gradient in evaporation ponds of the San Francisco Bay estuary. Unpublished manuscript. U.S.: U.S. Geological Survey.

Takekawa, J. Y., Miles, A. K., Schoellhamer, D. H., Athearn, N. D., Saiki, M. K., Duffy, W. D., ... Jannusch, C. A. (2006). Trophic structure and avian communities across a salinity gradient in evaporation ponds of the San Francisco Bay estuary. Hydrobiologia, 567, 307-327.

Takekawa, J. Y., Miles, A. K., Schoellhamer, D. H., Jaffe, B., Athearn, N. D., Spring, S. E., ... Lionberger, M. A. (2005). South Bay Salt Ponds Restoration Project, short-term data needs, 2003-2005 final report. U.S.: U.S. Geological Survey.

Takekawa, J. Y., Page, G. W., Alexander, J. M., \& Becker, D. R. (2000). Waterfowl and shorebirds of the San Francisco Estuary. In Olofson, P. R. (Ed.), Baylands ecosystem species and community profiles: Life histories and environmental requirements of key plants, fish and wildlife (pp. 309-316). California: Goals Project, San Francisco Bay Regional Water Quality Control Board.

Taylor, D. W. (1981). Freshwater mollusks of California: adistributional checklist. California Fish and Game, 67(3), 140-163.

Thebault, J., Schraga, T., Cloern, J., \& Dunlavey, E. (2008). Primary production and carrying capacity of former salt ponds after reconnection to San Francisco Bay. Wetlands, 28(3), 841-851. 
Thompson, J. (2010). Pre- and post-restoration assessment of benthic communities: Interim report. Collaborative agreement 2009-0211 United States Geological Survey.

Thompson, J., Hieb, K., McGourty, K., Cosentino-Manning, N., Wainwright-De La Cruz, S., Elliot, M., \& Allen, S. (2007). Habitat type and associated biological assemblages. U.S.: National Oceanic and Atmospheric Administration.

Thompson, J. K. (1999). The effect of infaunal bivalve grazing on phytoplankton bloom development in South San Francisco Bay. Ph.D Thesis, Stanford University, Palo Alto, California, United States.

Thompson, J. K., \& Shouse, M. K. (2004). A summary of our knowledge of south San Francisco Bay infaunal invertebrate community. Unpublished report. U.S.: U.S. Geological Survey.

Tilman, D. (1999). The ecological consequences of changes in biodiversity: a search for general principles. Ecology, 80, 1455- 1474.

Tilman, D., Lehman, C. L., \& Thomson, K. T. (1997). Plant diversity and ecosystem productivity: theoretical considerations. Proceedings of the National Academy of Sciences of the United States, 94, 1857-1861.

United States Environmental Protection Agency. (2010). Wetlands. Retrieved March 18, 2011 from http://www.epa.gov/bioiweb1/aquatic/wetlands.html.

United States Geological Survey. (1997). San Francisco Bay program: Lessons learned for managing coastal water resources. Retrieved September 19, 2013 from http://www.water.usgs.gov/wid/html/sfb.html.

United States Geological Survey. (2007). Water quality of San Francisco Bay. Retrieved September 19, 2013 from http://www.sfbay.wr.usgs.gov.

United States Geological Survey. (2010). Invertebrate rinsing and sieving standard operating procedure and invertebrate sorting lab manual. Unpublished standard operating procedures. Vallejo, CA: United States Geological Survey.

van Dolah, R. F. (1978). Factors regulating the distribution and population dynamics of the amphipod Gammarus palustris in an intertidal salt marsh community. Ecological Monographs, 48, 191-217.

Vassallo, M. T. (1969). The ecology of Macoma inconspicua in central San Francisco Bay: The vertical distribution of the Macoma community. Veliger, 11, 223-234.

Ver Planck, W. (1958). Salt in California. CA: California Division of Mines. 
Warnock, N., Page, W., Ruhlen, T. D., Nur, N., Takekawa, J. Y., \& Hanson, J. T. (2002). Management and conservation of San Francisco bay salt ponds: effects of pond salinity, area, tide, and season on Pacific flyway waterbirds. Waterbirds, 25(2), 79-92.

Williams, C. B. (1943). Area and number of species. Nature, 152, 264-267.

Wissinger, S. A. (1999). Ecology of wetland invertebrates: synthesis and applications for conservation and management. In Batzer, D. P., Rader, R. R., \& Wissinger, S. A. (Eds.), Invertebrates in freshwater wetlands of North America: Ecology and management (pp. 1043-1086). New Jersey: John Wiley \& Sons, Inc.

Zar, J. H. (1984). Biostatistical analysis. University of Michigan: Prentice-Hall. 
APPENDIX A. SF2 summer invertebrate identification.

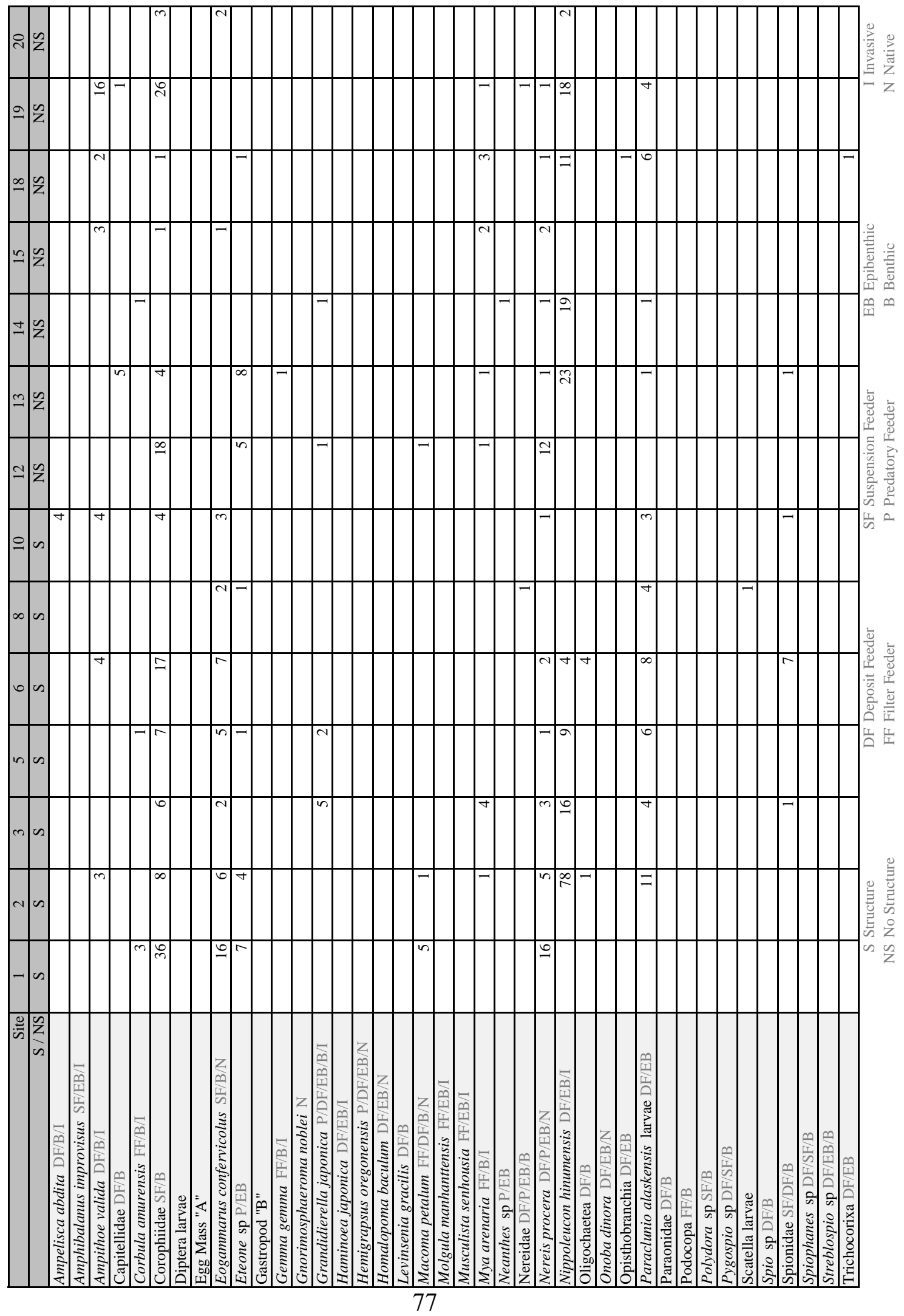


APPENDIX B. SF2 fall invertebrate identification.

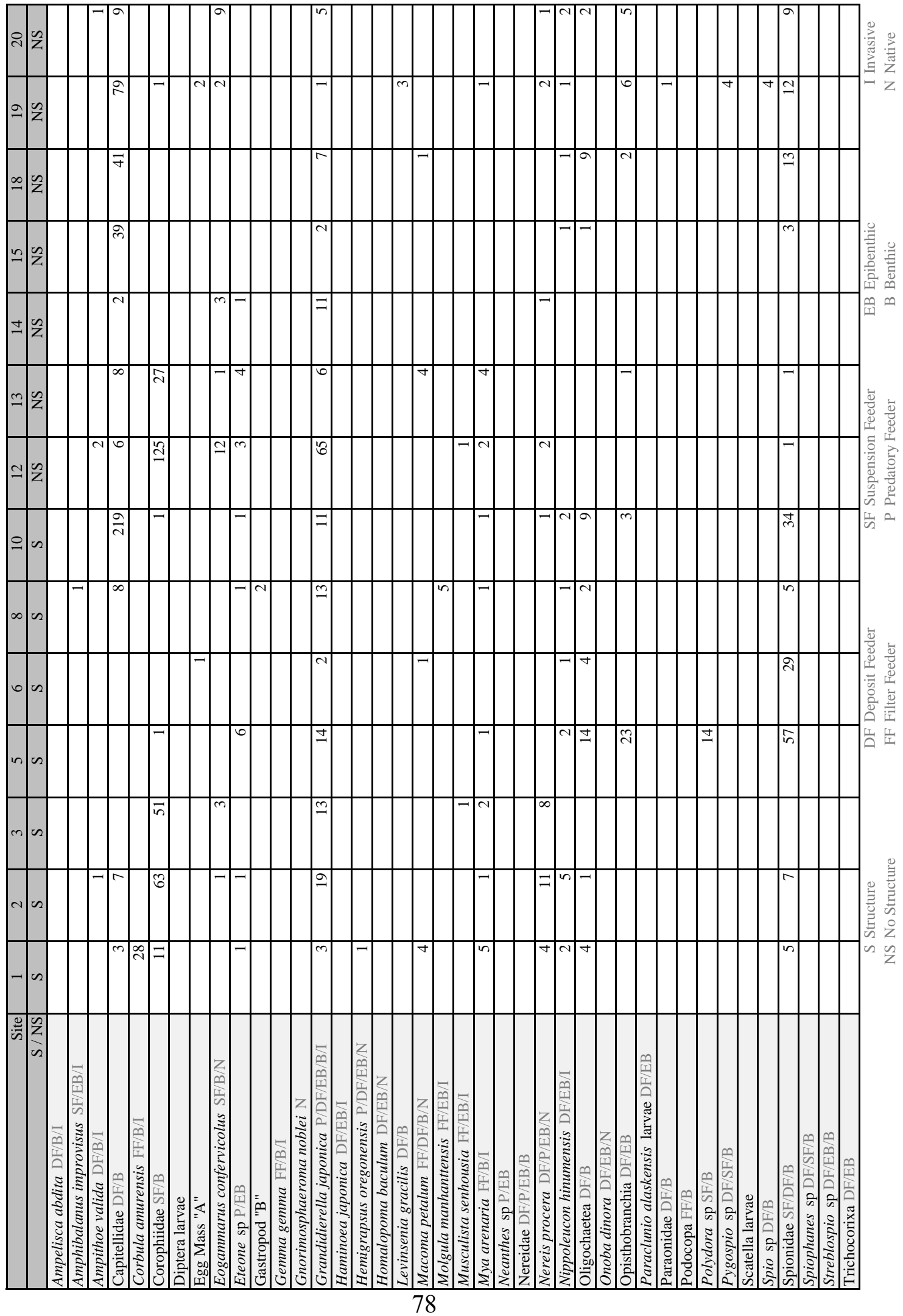


APPENDIX C. A1 summer invertebrate identification.

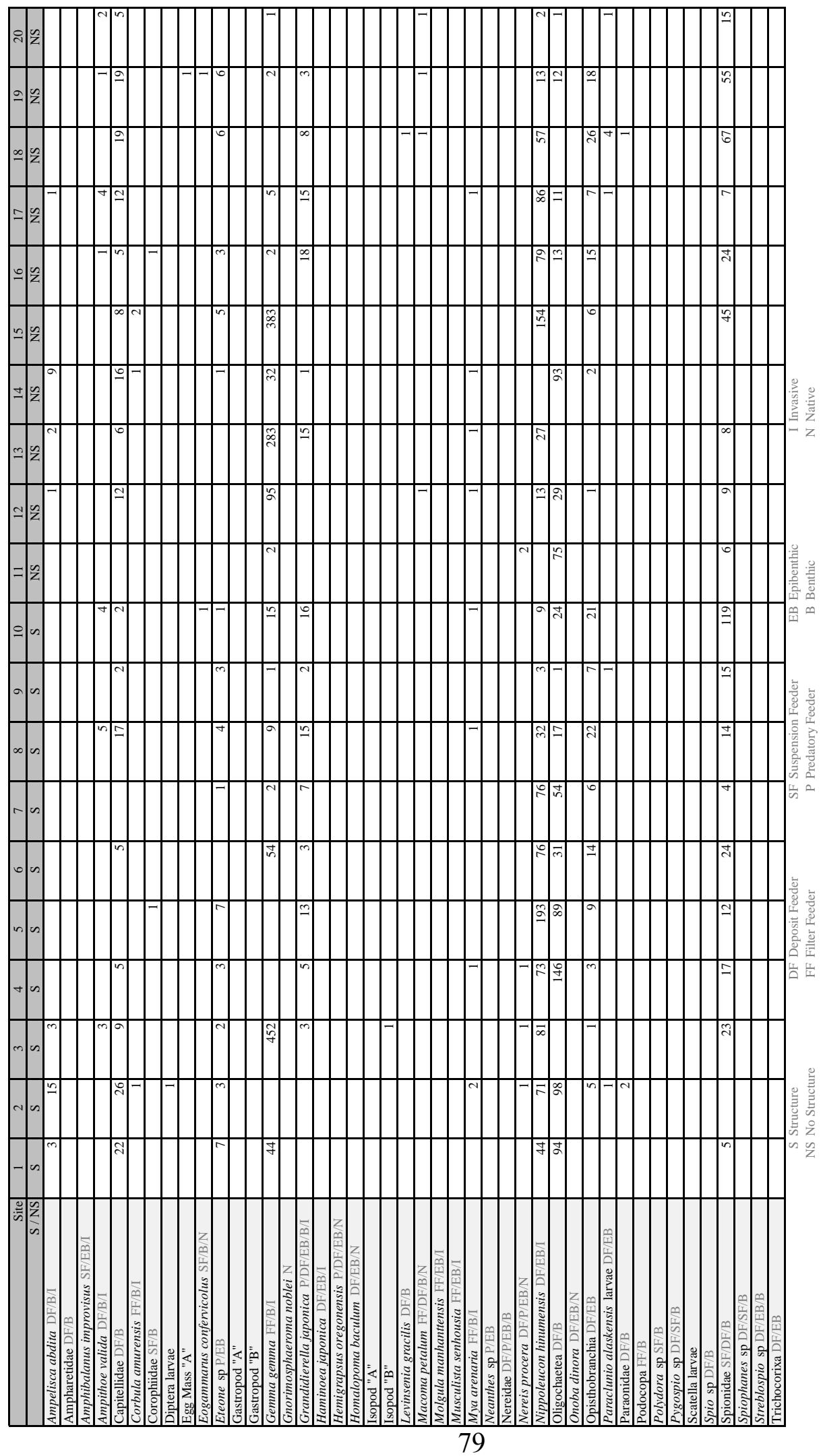


APPENDIX D. A1 fall invertebrate identification.

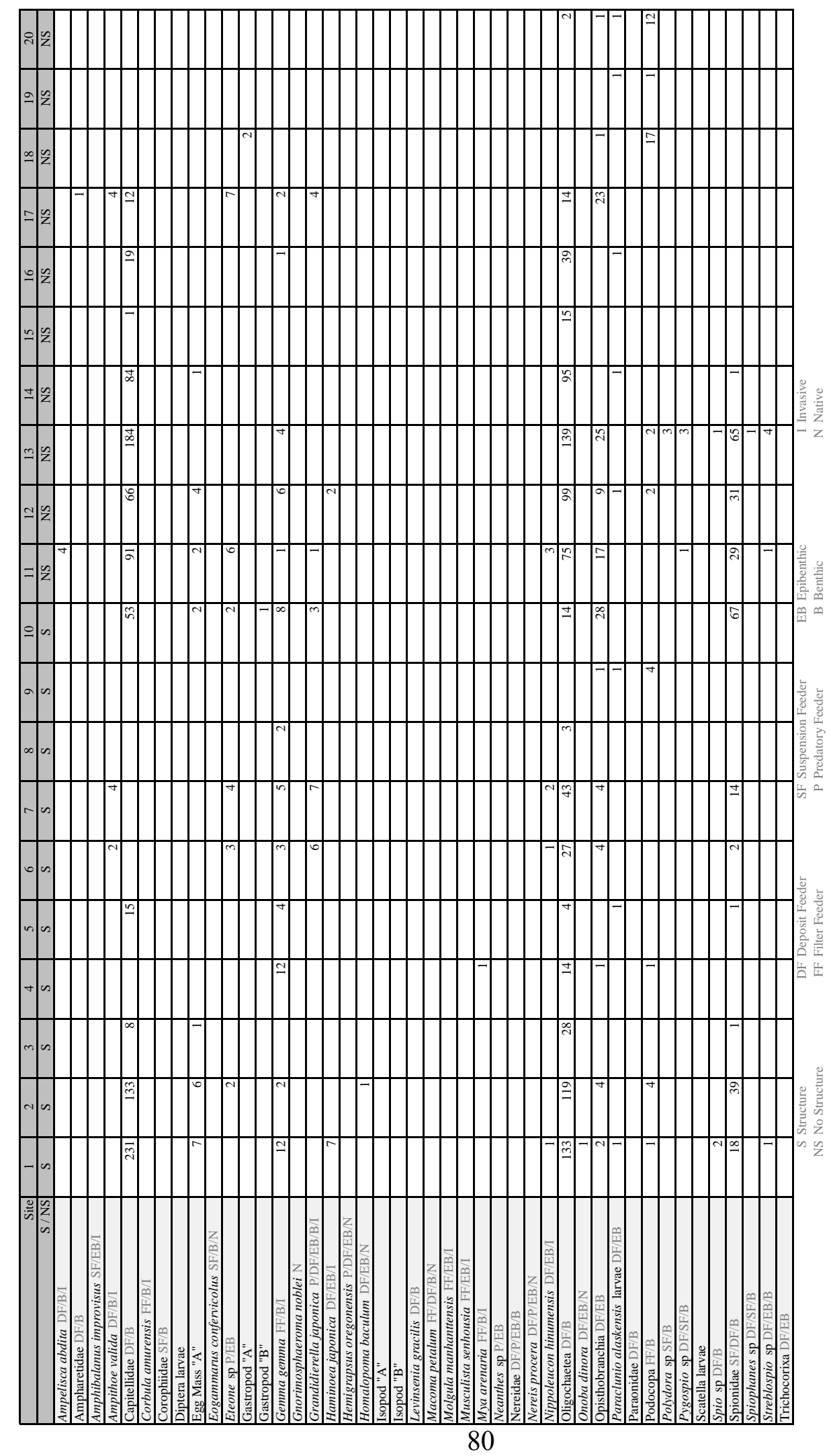


APPENDIX E. Critical Values of the Spearman's Ranked Correlation Coefficient (rs) (Zar, 1984).

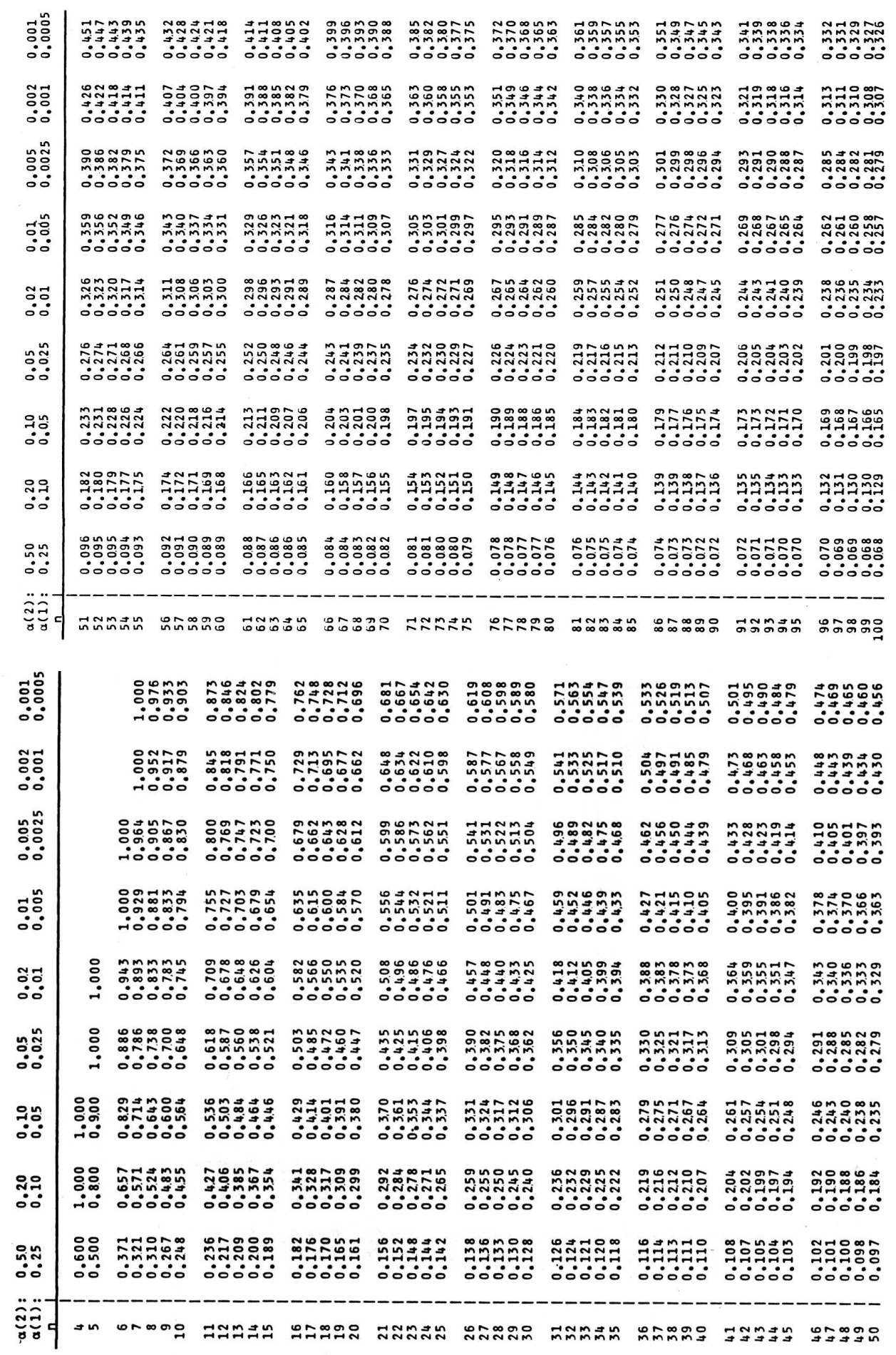

